Serie Investigación

LOS CONSEJOS COMUNITARIOS DEL MEDIO ATRATO EN LA VÍA DEL POSDESARROLLO HACIA UN MODELO DELIBERATIVO

DE ORGANIZACIÓN DE LAS COMUNIDADES NEGRAS

Sergio Angel Baquero 


\section{Los consejos comunitarios del medio Atrato en la vía del posdesarrollo \\ Hacia un modelo deliberativo de organización de las comunidades negras}

Sergio Angel Baquero

进年 $\begin{gathered}\text { UNIVERSIDAD } \\ \text { SERGIO ARBOLEDA }\end{gathered}$

Bogotá, Colombia. 2014 


\section{Baquero, Sergio Angel}

Los consejos comunitarios del medio Atrato en la vía del posdesarrollo: hacia un modelo deliberativo de organización de las comunidades negras / Sergio Angel Baquero - Bogotá: Universidad Sergio Arboleda. Escuela de Política y Relaciones Internacionales, 2014.

$140 \mathrm{p}$.

ISBN: 978-958-8745-84-8

1. NEGROS - PARTICIPACIÓN GIUDADANA - MEDIO ATRATO (CHOCÓ, GOLOMBIA)

2. PARTICIPACIÓN COMUNITARIA - MEDIO ATRATO (CHOCÓ, COLOMBIA)

3. DEMOCRACIA DELIBERATIVA - MEDIO ATRATO (CHOCÓ, COLOMBIA) 323.1196086151 ed. 21

Los consejos comunitarios del medio Atrato en la vía del posdesarrollo Hacia un modelo deliberativo de organización de las comunidades negras

ISBN: 978-958-8745-84-8 (rústica)

ISBN: 978-958-8745-85-5 (.pdf)

(c) Sergio Angel Baquero

email: sergio.angel@usa.edu.co

\section{Universidad Sergio Arboleda}

Escuela de Política y Relaciones Internacionales

Edición: febrero de 2014

Queda prohibida toda reproducción por cualquier medio sin previa autorización escrita del editor.

El contenido del libro no representa la opinión de la Universidad Sergio Arboleda y es responsabilidad del autor.

Edición: Yadira Caballero Quintero

y Carlos Andrés Caho Rodríguez

Calle 74 No. 14-14

Teléfono: (571) 3257500 ext. 2131/2260

www.usergioarboleda.edu.co

Bogotá, D.C.

Directora de Publicaciones Científicas:

Yadira Caballero Quintero

yadira.caballero@usa.edu.co

Director del Fondo de Publicaciones:

Jaime Arturo Barahona Caicedo

jaime.barahona@usa.edu.co

Diseño y diagramación: Maruja Esther Flórez Jiménez

Impresión: Digiprint

Bogotá, D.C. 
A mi querida Neca... 



\title{
AGRADECIMIENTOS
}

\begin{abstract}
gradezco especialmente a Lucero Perea por acogerme - en su hogar y servirme de enlace con todas las personas a las que entreviste durante mi estadía en el Choco; a todos y cada uno de los entrevistados por su tiempo y sus valiosísimos aportes; a John Jairo Londoño por sus comentarios oportunos; a Ivonne León por sus innumerables ayudas; a mi familia por las presiones y apoyos; y al profesor Oscar Mejía por su paciencia y enseñanzas a lo largo de este proceso.
\end{abstract}





\section{GONTENIDO}

Capítulo 1.

\section{LA TITULAGIÓN GOLEGTIVA EN EL MEDIO ATRATO: UN ESTADO DEL ARTE DE LOS CONSEJOS \\ COMUNITARIOS.}

El conflicto y la violencia en el Pacífico ...................................... 18

Los proyectos de desarrollo rural y los intereses corporativos.......28

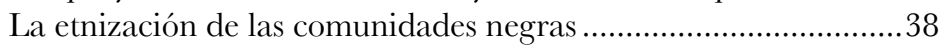

La política de titulación colectiva y la formación de los

Consejos Comunitarios

Los movimientos sociales y los estudios de género........................50

\section{Capítulo 2.}

\section{EL POSDESARROLLO Y LA DEMOGRAGIA}

DELIBERATIVA: MARGOS EXPLICATIVOS PARA EL ANÁLISIS DE LOS CONSEJOS GOMUNITARIOS ...................55

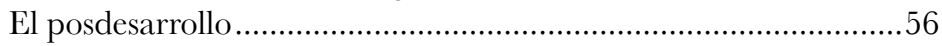

Críticas al desarrollo...............................................................56

Los postulados del posdesarrollo.........................................60

La génesis del concepto..................................................60

Acercamientos teóricos al posdesarrollo.................................62 62

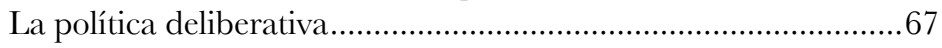

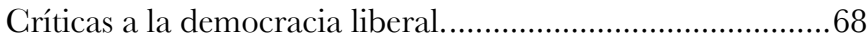

El problema de la representación.........................................69

Los problemas de agencia, favoritismo y corrupción................ 71

Los postulados de la democracia deliberativa ......................76

Puntos de encuentro: Democracia deliberativa y posdesarrollo.............83

Críticas a la democracia liberal y al desarrollo....................85

Postulados deliberativos del posdesarrollo............................87

Capítulo 3.

LOS CONSEJOS COMUNITARIOS EN EL MEDIO

ATRATO DESDE LA PERSPEGTIVA DEL POSDESARROLLO

Y LA DEMOGRACIA DELIBERATIVA .........................................91

Revaloración de las culturas vernáculas.....................................91

Entre la propiedad privada y la titulación colectiva......................97 


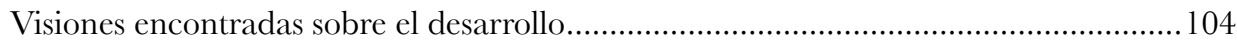

Las paradójicas formas de organización liberal.......................................................115

Prolegómenos a un modelo deliberativo de organización ...............................................123

GONGLUSIONES ..................................................................................................129

\section{LISTA DE TABLAS}

Tabla 1. Documentos CONPES para población afrocolombiana del Pacífico $(1992-2010)$ .36 


\section{PRESENTAGIÓN}

Hl presente libro es el resultado de la tesis presentada en Sla Universidad Nacional de Colombia para optar al título de Magíster en Estudios Políticos. La investigación tiene por objeto construir un puente de comunicación entre la democracia deliberativa y el posdesarrollo, buscando con ello establecer una lectura no occidental sobre los consejos comunitarios del Medio Atrato (Chocó, Colombia). Metodológicamente se fundamenta en un trabajo de campo elaborado en el Municipio de Quibdó; en donde a través de entrevistas semiestructuradas en profundidad se indagó con diferentes actores sociales -campesinos, líderes, misioneros, consultivas, profesionales- sobre el fenómeno organizativo posterior a la Ley 70 de 1993. En este sentido, la indagación llevó a demostrar que los consejos desde una concepción liberal de democracia movilizan lógicas de burocratización, representación y corrupción que pervierten un modelo plausible de organización en defensa del territorio y los derechos étnicos. En consecuencia, sobre la base de visiones diferenciales sobre "la vida buena" se plantean lineamientos generales que sirvan de insumo para la formulación de un modelo deliberativo de organización, en el que las comunidades se sientan más a gusto con su propia identidad y en el que sea posible incluir racionalmente y razonablemente a todos los pobladores de la región. 



\title{
INTRODUGGIÓN
}

\begin{abstract}
"Oye -le dice el científico al pescador- ¿Por qué te pasas todo el día en la hamaca, cuando el mar está lleno de peces que no están más que esperando a que vayas y los pesques?" El pescador algo desconcertado por el afán del científico, lo mira y responde: ¿Por qué querría yo atrapar todos los peces?" El científico, entusiasmado de que el pescador al fin le haya respondido, le explica: "cuantos más peces atrapes más podrás vender en el mercado y más dinero conseguirás [...]” (Oslender, 2008)
\end{abstract}

En enero del año 2008, después de haber decidido emprender mis estudios de Maestría en Estudios Políticos, visite las playas de Juanchaco y Ladrilleros en el Pacífico colombiano, hasta entonces mis motivaciones como estudiante de filosofía se orientaban por el lado de los medios de comunicación y la construcción de una "realidad simulada", pero estos intereses iban a cambiar drásticamente después del viaje. Más allá del colorido de los paisajes, las rumiantes olas, los arenosos riscos y las palmeras encorvadas, la imagen precipitada que me lanzaba el puerto de Buenaventura y el intrincado trayecto en lancha eran devastadores: la pobreza extrema, las viviendas improvisadas, la basura jadeante y la precariedad sanitaria, eran solo algunas de las imágenes que me asolaban. No tuve más alternativa que ceder ante el saber. Mi visión moderna del mundo se impuso y sentencie: "El Pacifico es una geografía del subdesarrollo".

Había asumido la postura del científico; no entendía por qué a pesar de unas condiciones tan deplorables los habitantes de estas playas se sentían felices de vivir allí. Luego, instalado en el hotel y presto a conocer el lugar decidí emprender camino con un guía quien me llevó a lo que allí llaman "piscinas naturales", y que no es otra cosa que formaciones rocosas que se hacen al interior de los 
magníficos paisajes de manglar. Viajé en una chalupa construida en madera por los indígenas Emberas, y ya en mi destino, pude tener una experiencia inigualable: "compartí mi espacio en el agua con carideos o camarones -como se les llama más usualmente-". Hasta ahora los mariscos solo habían sido un plato exquisito en medio de cocteles o comidas, pero ahora eran parte integrante de mi experiencia.

Pude hablar con el guía y en medio de mi confusión, por experiencias tan dispares, le pregunte por sus condiciones de vida en Juanchaco. Él sin mayores rodeos afirmó que no viviría en un lugar diferente y menos aún en una ciudad como Bogotá. Desde su punto de vista, aunque el acueducto y el alcantarillado eran precarios prefería vivir allí en medio de palmeras, playas y manglares, que estar en medio de una "selva de cemento". Sin duda, su postura era incomprensible desde el punto de vista occidental: preferir un lugar sin servicios públicos básicos a una ciudad con todos los recursos sanitarios, era algo que en la lógica del científico de nuestra historia resultaba inconcebible.

Pero, mis convicciones empezaron a cambiar y pude ver que en mi visión del desarrollo se transponían las necesidades citadinas sobre las necesidades de los pobladores de la región; cuando sostenía la sentencia del subdesarrollo no hacía otra cosa que establecer juicios sobre la base de una experiencia disímil y una colonización en el saber. Por eso es que el fin de la historia que plantea Ulrrich Oslender (2008) resulta tan cautivador:

¿Y qué haré con todo ese dinero?, le pregunta de nuevo el pescador. "Bueno, puedes construir una bodega de refrigeración y ganar aún más dinero". El pescador, que sigue relajado en la hamaca, lo vuelve a interrogar: " $\mathrm{i} Y$ por qué querría yo hacer eso?" El científico, impaciente por la incomprensión del hombre, estalla: “iPor Dios!, pues puedes emplear otros pescadores que pesquen por ti”. El pescador, impasible ante esta posibilidad, vuelve a preguntar: “PPor qué querría yo hacer eso?” Ahora el científico está a punto de volverse loco. "¡Por todos los cielos!”, ipues no tendrás que volver a trabajar y podrás pasarte el día entero tirado en la hamaca!" en este punto el pescador sonríe y, estirándose, responde: "bueno, eso es lo que estoy haciendo ahora (p. 132).

Es preciso cambiar nuestros marcos conceptuales para interpretar las lógicas disímiles de pueblos como los del Pacífico. Comprender estos espacios desde visiones occidentales, capitalistas y liberales presupone una forma de dominación; presupone una imposición. Es menester abrir caminos hacia el diálogo intercultural en el que las prácticas vernáculas y los saberes tradicionales 
tengan vocación y status de conocimiento. De tal manera que el experto, el técnico, el político y el campesino del Pacífico puedan establecer consensos en los que no prime la voz de ninguno y en el que todos puedan participar activamente desde sus concepciones particulares de la "vida buena". En estos términos, el problema del científico que aparece en la historia de Oslender es, que pretende imponer su lógica capitalista de acumulación, sobre la lógica extractiva del pescador.

Bajo estas circunstancias, la investigación que acá se presenta contempla dos marcos conceptuales; de un lado el posdesarrollo, desde el que se busca repensar las formas de organización social, económica y cultural, sobre la base de dos principios: la diferencia cultural y las necesidades económicas de carácter no acumulativo (Escobar, 1996); y la democracia deliberativa, desde la que se busca deconstruir la concepción liberal de la democracia y proponer alternativas discursivas de gobierno (Habermas, 1999).

Con base en estos marcos conceptuales se espera explorar el tema de los consejos comunitarios en el Medio Atrato (Chocó, Colombia). Es importante aclarar que el salto de Buenaventura hasta Quibdó se dio motivado por los procesos organizativos que las comunidades gestaron en orden a defender sus derechos. Pero, teniendo en cuenta que los consejos comunitarios se extienden por toda la cuenca del Pacífico, se debe precisar por qué se escogió el Medio Atrato y no otro espacio determinado. La razón por la cual se decidió escoger este lugar y no otro como el Pacífico nariñense o el Bajo Atrato en el Chocó tiene que ver con el hecho de que allí se encuentra el proceso organizativo de la Asociación Campesina Integral del Atrato -ACIA; que siguiendo a Carlos Agudelo puede ser interpretado como uno de los movimientos pioneros en defensa del territorio y los derechos étnicos de las comunidades negras. Y no es en vano, teniendo en cuenta que la ACIA "logra - a través de los acuerdos de Buchadó- inicialmente que el Estado le reconozca el derecho de manejo del área en que se asentaban dichas poblaciones pero sin aceptar la identificación como grupo étnico que el movimiento había planteado ni la titulación colectiva de propiedad sobre los territorios" (Agudelo, 2005, p. 178). Logros que la Constitución de 1991 y la Ley 70 de 1993 habrían de otorgar a las comunidades negras de la Cuenca del Pacífico.

De este modo, teniendo en cuenta los marcos teóricos propuestos y el tema en cuestión, el presente libro buscar demostrar como hipótesis que: la 
literatura sobre los consejos comunitarios no ha examinado la lógica liberal de este tipo de organizaciones, lo cual representa un vacio enorme en el tema, teniendo en cuenta que las comunidades afrodescendientes de la cuenca del Pacífico son reconocidas como un grupo étnico en la medida que comparten cierta historia, cultura y tradiciones, aspectos que difieren de una concepción occidental del mundo y de una lógica organizativa liberal. En este sentido se espera establecer con base en los postulados del posdesarrollo y la democracia deliberativa, que aún cuando la Ley 70 de 1993 representa un avatar sin precedentes en el reconocimiento de los derechos étnico-territoriales, la estructura organizativa del consejo es ajena a la cultura de las comunidades negras, y por ende produce resultados funestos en términos de sus intereses, al propiciar la separación entre las organizaciones de base y los líderes. En estos términos se propone un modelo alternativo de organización afianzado sobre la base de la discusión, en donde todos los miembros de la comunidad puedan participar, es decir, que en conformidad con el lema del Foro Social Mundial se cree que así como "otros mundos son posibles" y "otro desarrollo es posible" - siguiendo a Escobar-, también otras formas de organización diferentes a las liberales son posibles.

Dicho lo anterior, el orden que se seguirá para demostrar la hipótesis es el siguiente: en el primer capítulo se llevará a cabo una exploración de los diferentes trabajos que se han orientado al tema de los consejos comunitarios. Se pretende demostrar a través de un estado del arte que son muy tangenciales las referencias al problema de su organización liberal. En el segundo capítulo buscando llevar a cabo una fundamentación teórica, se presentarán los dos marcos teóricos el posdesarrollo y la democracia deliberativa. El propósito allí será establecer los insumos para un análisis práctico de los consejos, buscando además entablar puentes de comunicación entre las dos perspectivas teóricas. Finalmente, en el tercer capítulo se llevará a cabo un análisis de los consejos comunitarios en el Medio Atrato desde los dos marcos teóricos planteados. Allí se buscará demostrar que el modelo liberal de democracia resulta obsoleto frente a las estructuras socio-culturales de la gente del Pacífico. Promoviendo como alternativa una concepción deliberativa de organización que genere una auténtica participación de las comunidades.

Es importante aclarar que en términos metodológicos la investigación contó con un trabajo de campo llevado a cabo en el municipio de Quibdó 
durante el mes de julio del año 2010. Se pudo conocer de cerca el proceso organizativo de las comunidades negras, logrando entablar diálogos con diferentes actores. Fue posible contactar misioneros, consultivas de alto nivel, líderes campesinos, profesionales afrocolombianos y académicos. Las diferentes miradas sobre el proceso de conformación de los consejos comunitarios en el Medio Atrato fueron consolidadas a través de entrevistas semiestructuradas en profundidad. 



\section{Capítulo 1 .}

\section{LA TITULAGIÓN GOLEGTIVA EN EL MEDIO ATRATO: UN ESTADO DEL ARTE DE LOS GONSEJOS GOMUNITARIOS}

$\mathrm{B}$ n orden a demostrar que la producción académica que ha discurrido sobre el tema de la formación de los consejos comunitarios y la titulación colectiva en Colombia no ha atendido al problema de la organización liberal que sustenta la Ley 70 de 1993 y el Decreto 1745 de 1995, es menester presentar una recopilación de los principales trabajos en los que se ha hablado de la movilización de las comunidades negras de las décadas de los ochenta y noventa. Cabe anotar que en la revisión que se hizo no se halló ningún trabajo elaborado por un politólogo o por un profesional diferente de las ciencias sociales que centrara su atención en el problema de la organización socio-política de los consejos. A lo sumo se esbozaba en trabajos como el de Oslender (2008), en el que se planteaba que la lógica del consejo era ajena a la lógica de los ríos y a las tradiciones y costumbres del pueblo negro.

En este sentido, dentro de la amplia literatura sobre afrodescendientes en Colombia (Restrepo \& Rojas, 2008) solo se tomaron aquellos trabajos en los que se hacen referencias explícitas a los consejos comunitarios. De manera que el capítulo explora en un primer momento aquellos documentos en los que se atiende específicamente el problema del Conflicto; para luego en un segundo momento, centrar la atención en las publicaciones que se han acercado al Pacífico desde la perspectiva del desarrollo y los 
intereses corporativos; pasando a un tercer momento en el que se atenderá el tema de los consejos desde la perspectiva de la etnización de las que se sustentan. Fijando en un cuarto momento la atención sobre las publicaciones en las que las comunidades negras, la identidad y tradiciones que han trabajado formalmente en el proceso de formación de los consejos y la correspondiente legislación que los sustenta. Finalmente, dejando en un quinto momento, aquellas investigaciones en las que se ha trabajado la organización de las comunidades negras desde la perspectiva de los estudios de género y el papel de la mujer.

\section{El conflicto y la violencia en el Pacífico}

De ninguna manera el siguiente apartado buscará dilucidar las intrincadas estrecheces y complejidades del conflicto armado en el Pacífico colombiano; antes bien, se propone un acercamiento a las diferentes publicaciones en las que se ha trabajado el tema de los consejos comunitarios desde la perspectiva del conflicto. Así que resulta conveniente hacer dos aclaraciones: la primera, que aún cuando el conflicto auspiciado por los grupos al margen de la ley es el item más relevante en relación con la vulneración de los derechos de las comunidades negras, no es el único conflicto que se presenta en relación con el territorio, pues también los hay con otros grupos étnicos y con intereses corporativos. La segunda, siguiendo a Oscar Almario se puede afirmar que la intensificación de la violencia y el desplazamiento de las comunidades negras representa una paradoja, en tanto que se da precisamente en el momento en el que estas comunidades históricamente excluidas habían logrado darle forma a un proyecto étnico y territorial propio (Almario, 2003).

En este sentido, Odile Hoffmann (2002) sostiene que la Ley 70 de 1993 y la movilización social producto de la reivindicación de los derechos territoriales de las comunidades negras, alimenta la conflictividad y genera contradicciones. Siguiendo su argumentación se puede afirmar que el reconocimiento de derechos territoriales que se les da a las comunidades negras sobre predios que antes de la Ley 70 de 1993 eran considerados como baldíos $^{1}$, produce un conflicto con las comunidades indígenas y los campesinos

Siguiendo a Carlos Agudelo "la ley 2 de 1959 convierte las tierras bajas del Pacífico en tierras baldías o espacios vacíos propiedad de la Nación, desconociendo el proceso de poblamiento diverso y móvil de las poblaciones negras de esta región. Esta ocupación del espacio se había iniciado desde el período colonial, pero no estaba legitimada 
Los consejos comunitarios del medio Atrato en la vía del posdesarrollo Hacia un modelo deliberatorio de organización de las comunidades negras

por la delimitación de la propiedad. De este modo, teniendo en cuenta que las comunidades indígenas ya tenían con anterioridad títulos colectivos, reconocidos a través de resguardos y los campesinos sobre todo paisas y chilapos $^{2}$ ya tenían propiedad reconocida a través de escrituras individuales, se puede decir que "con las titulaciones se agudizan los conflictos territoriales con los vecinos que pueden en ciertos casos adquirir el matiz de 'conflicto interétnico', entre indios y negros, o blancos y negros, cuando en el fondo se trata de luchas por el territorio" (Hoffmann, 2002, p. 291).

El conflicto interétnico se produce sobre todo en función de la "yuxtaposición de espacios geográficos", es así que por ejemplo el territorio destinado para los resguardos se sobrepone al territorio destinado para el consejo comunitario, lo cual lleva a que se produzcan conflictos interétnicos; debido a que la ley le otorga igual derecho sobre el territorio a las dos etnias. Lo que resulta aún más inverosímil es que la lucha por el territorio de las comunidades negras se ha dado con ayuda de los indígenas y el descuido en la titulación ha ocasionado choques con aliados ancestrales ${ }^{3}$. Sin embargo, hay quienes piensan que existe oportunismo por parte de indígenas, paisas y chilapos en relación con la defensa del territorio. En relación con los primeros, por la disputa en torno a espacios considerados ancestrales por cada una de las etnias; en relación con los segundos, por la pugna entre propiedad privada y propiedad colectiva, dado que muchas titulaciones acaban por englobar territorios ya titulados individualmente ${ }^{4}$; y en relación con los terceros, porque en la mayoría de los casos, se busca excluir de los derechos

mayoritariamente por títulos de propiedad, entre otras razones porque justamente las modalidades de utilización del espacio adaptadas a las características del entorno natural implicaron una gran movilidad que se diferenciaba mucho de las formas de apropiación territorial de las regiones del interior del país" (Agudelo, 2005, pág. 176). En otras palabras, aun cuando las comunidades negras que habitaban las tierras bajas del Pacifico eran legítimas propietarias, nunca se habían ocupado de darle un sustento legal a su ocupación, dado que el esquema de titulación de la legislación colombiana, les era extraño e inadecuado para su subsistencia.

2 Se les llama chilapos a "todos aquellos campesinos mestizos, cordobeses en su mayoría, que migraron de sus tierras de origen para colonizar las tierras chocoanas" (Ruiz, 2006, p. 6).

Ver el apartado sobre la etnización de las comunidades negras en este capítulo.

4 Es preciso anotar que también hay familias afrochocoanas que han titulado individualmente sus tierras y han visto conflicto con la titulación colectiva. 
étnicos de las comunidades negras a campesinos mestizos que han vivido igual o más tiempo que muchas de las familias negras que residen en la zona.

Lo que está en pugna es el derecho de los chilapos a hacer parte de los consejos comunitarios, pues mientras que los miembros más radicales del movimiento negro arguyen que los mestizos no hacen parte de la etnia negra y solo se han aprovechado oportunistamente del contexto de la Ley 70 de 1993; otros miembros más neutrales han afirmado que el concepto de etnia engloba a las comunidades mestizas de la zona y les otorga iguales derechos sobre el territorio. Al respecto se pregunta un artículo del boletín virtual Palmo a Palmo, de la comunidad de Asociación de Consejos Comunitarios y Organizaciones del Bajo Atrato (ASCOBA) ¿son los mestizos sujetos de derechos en el marco de esta ley? La respuesta es que es necesario distinguir entre la raza y la etnia, pues la primera se refiere normalmente a los aspectos genotípicos de los humanos, mientras que la segunda comprende factores culturales y biológicos. Así es que el argumento utilizado para excluir a los chilapos de los derechos étnicos y territoriales habitualmente parte de la incomprensión del concepto de etnia, o bien del uso instrumental que se le da al concepto para interpretarlo según convenga como raza (ASCOBA, 2010). En estos términos el artículo agrega que:

Para desestimar la participación y en general considerar a un "mestizo" como sujeto de derecho en el marco de la ley 70 de 1993, no es suficiente acudir a su aspecto biológico, sino que debe ser demostrado que dichas personas no se reconocen como miembros de la etnia, que no comparten valores, cosmovisión, costumbres, etc. (p. 7).

En consecuencia, aun cuando la dicotomía entre la raza y la etnia está en el centro del conflicto es posible recapitular las dos posiciones así: de un lado, se puede pensar que al aceptar a los chilapos dentro de la etnia negra, muchos foráneos harán uso del argumento de la etnicidad para reclamar derechos que consuetudinariamente no les pertenecen; y de otro , al excluir a los chilapos se puede propiciar la expulsión de familias que no solo han habitado ancestralmente estas tierras, sino que además han participado de la lucha por el territorio. Lo cierto es que hay un fuerte conflicto por el territorio entre negros, mestizos e indígenas que bien puede ser interpretado como étnico.

De manera que retomando el argumento de Odile Hoffmann (2002), se puede anotar que además de los conflictos interétnicos también se pro- 
ducen conflictos internos que "suelen nacer de las nuevas jerarquías que se dan entre habitantes que aspiran a un mismo territorio colectivo y que participan en la movilización étnico-territorial: entre escolarizados y no escolarizados, rurales y urbanos, ancianos y jóvenes, etc.” (p. 193). Las nuevas jerarquías que empiezan a emerger por la defensa del territorio, entablan diferencias en el interior de las comunidades, que bien pueden darse por la competencia en el liderazgo de la comunidad, o bien por el desconocimiento de la ley 70 de 1993 de muchos de los moradores de la cuenca del Pacífico. Lo cierto es que los consejos comunitarios a pesar de representar los intereses de la comunidad negra en general separan en asuntos esenciales a los moradores de la región: algunos que defienden la autonomía de los territorios frente a los intereses del capital; otros que ven la necesidad de subordinar los consejos a los intereses corporativos buscando la sustentabilidad de la comunidad; y otros más que simplemente no se interesan por el tema de la titulación colectiva y no se hacen partícipes del proceso organizativo (Oslender, 2008).

En este orden de ideas, cobran relevancia también los conflictos territoriales producto de las ambiciones de los agentes económicos. Ambiciones que a juicio de Hoffmann, sea dan en el sur a través de los cultivos de palma africana; y en el norte a través de los intereses mineros, madereros y turísticos. En consecuencia, el conflicto se produce cuando la ley 70 de 1993 le reconoce a la comunidad negra el derecho a la titulación colectiva, pues este va en contravía con los intereses mercantiles de las empresas con interés en la región. Contrario a lo que se podría pensar, no es esta ley la causa del conflicto, pues como lo agrega Hoffmann (2002):

Se podría interpretar la ley 70 como un mecanismo implementado por el Estado, bajo presión de las agencias internacionales, entre otras, para legalizar títulos y aclarar los derechos de propiedad, base y condición de cualquier inversión de gran escala. Así solamente, aunque fuera bajo forma de títulos colectivos, se puede propiciar la intervención de agentes privados en campos estratégicos a corto o mediano plazo (explotación maderera, hidrológica, turística, minera, de la biodiversidad). Hubo allí una convergencia objetiva entre las perspectivas neoliberal y étnica para apoyar un verdadero "proyecto de Estado". En esta alianza desigual y coyuntural, la dimensión étnica fue casi un pretexto para facilitar un proceso de normalización jurídica indispensable para los actores económicos (p. 195-196). 
Al decir esto se cuestiona de fondo el contenido de la ley 70 de 1993, pues ésta ya no estaría orientada a reconocer los derechos territoriales de las comunidades negras y mucho menos a reconocer su etnización, sino que por el contrario abriría el camino para la expropiación y explotación de los territorios ancestrales a manos de los grandes capitales. Pues bien, dejando de lado por ahora los intereses corporativos sobre los que se espera profundizar más adelante, lo que se puede decir es que además de los conflictos étnicos y los choques en el interior de los las comunidades también existen con las empresas interesadas en el desarrollo de la región. Pero a pesar de que todos estos conflictos revisten gran importancia en la comprensión de los consejos comunitarios, quizás el conflicto de mayor trascendencia es el que se presenta por causas geopolíticas, a saber:

Por un lado, los actores de la guerra necesitan el territorio, de manera continua o temporal, sea para cultivar coca, transitar o residir una temporada con cierta seguridad. En esta perspectiva, narcos, guerrillas y paramilitares tienen claros objetivos geo-estratégicos en todo el litoral Pacífico, y el desalojo de los primeros territorios negros, en el Chocó, son evidencias de que ninguno de estos actores respetan los procesos étnico-territoriales en curso. Por otro lado, el control de amplias porciones del espacio nacional les asegura un poder de negociación para discusiones eventuales con el gobierno, así como el acceso a los recursos que existen en estos territorios (agrícolas, mineros, fiscales) (Hoffmann, 2002, p. 194).

En consecuencia, el conflicto producido por causas geopolíticas se refiere al posicionamiento estratégico de la región en el marco del conflicto armado interno que vive Colombia. Un conflicto que reviste gran complejidad, si se tiene en cuenta que involucra a las guerrillas, los paramilitares, las fuerzas del Estado, las bandas delincuenciales y el narcotráfico. Al respecto, Carlos Agudelo anota que en la geografía de la guerra en Colombia, la franja costera Pacífica se encontraba hasta los años 90 al margen de la dinámica del conflicto armado, llegando a afirmarse durante la época que el Pacífico era un ejemplo de paz, o bien, un laboratorio de convivencia pacífica (Agudelo, 2005). Pero, como lo anota Arturo Escobar (2005a):

La violencia armada apunta a: disgregar la integridad territorial, social y cultural de los grupos negros e indígenas, imposibilitándoles así el ejercicio de sus prácticas culturales; acabar con sus formas de organización, expulsando sistemáticamente a los militantes de sus movimientos, o, en ocasiones, eliminándolos; y apoderándose de los recursos naturales (madera, oro, plantaciones 
de palma africana) sin respeto alguno por la reglamentación sobre el medio ambiente y los derechos de los habitantes ( p. 52).

Es así como los años 90 representaron un punto de quiebre entre la histórica paz de la región y la violencia convulsiva del narcotráfico y los grupos al margen de la ley, que en palabras de Escobar tenían como objetivo último la eliminación de la diferencia cultural reconocida por la Constitución de 1991. Algo paradójico, teniendo en cuenta que se daba precisamente en el momento en el que las comunidades negras lograban concretar sus proyectos organizativos y defender sus territorios. En este sentido, siguiendo a Agudelo, el conflicto geopolítico se produce como consecuencia de la disputa entre guerrilleros y paramilitares por controlar las zonas de tránsito estratégico a lo largo de todo el litoral, extendidas desde el Urabá hasta Tumaco, pasando por los puertos de Buenaventura y Guapi en el Cauca. Rutas de tránsito que resultan atractivas teniendo en cuenta que sirven de entrada para el armamento proveniente de Panamá, la ampliación de los cultivos ilícitos y las nuevas vías de acceso al interior del país - como resultado de la terminación de la carretera panamericana- (Agudelo, 2005, p. 215).

Dicho esto, es preciso preguntarse en qué momento se produjo el recrudecimiento de la violencia en el Pacífico, pues hasta ahora son claras las razones del conflicto geopolítico y el contexto en el cual se produjo, pero no son claras las razones por las que se desplaza el conflicto, se fortalece la guerrilla y se unifican los paramilitares. En este sentido, es posible afirmar que aun cuando el conflicto subsiste en Colombia desde los años sesenta, y la expansión del fenómeno guerrillero a toda la geografía nacional se da durante la década del setenta, es en el año de 1995 que se produce un cambio sin precedentes en el conflicto armado que vivía el país; pues de un lado las FARC le propinan golpes sin precedentes a las fuerzas militares del Estado (toma de bases militares, impactos contundentes y secuestros masivos); y de otro lado los paramilitares que antes habían tenido una existencia fragmentada, se presentan como una fuerza unificada bajo el nombre de las Autodefensas Unidas de Colombia -AUG (Agudelo, 2005, pp. 212-219).

La llegada de la guerrilla a esta región respondió a la expansión territorial que grupos como las FARC, el ELN y el EPL llevaron a cabo a lo largo de los noventa. Estos grupos se expandieron desde el interior del país en dos frentes que confluyeron en el Pacífico y específicamente en el 
departamento del Chocó: "En el norte corresponde al desplazamiento de frentes guerrilleros desde el Urabá antioqueño y en el sur y centro a grupos provenientes de la cordillera occidental y el interior de los departamentos del Valle, Cauca, Nariño y Putumayo" (Agudelo, 2005, p. 214). Allí, el aumento en el accionar de estos grupos hizo que cambiara la estrategia militar y el interés geoestratégico, de manera tal que se produjeron por un lado acciones armadas como "retenes", "tomas" de caseríos, asaltos a puestos de policía y bases militares; y de otro, presiones políticas sobre candidatos a elecciones municipales, acompañadas por el incremento de los cultivos de coca y el control punitivo sobre la población (Agudelo, 2005). Acciones que dejaron en evidencia el interés de las FARC por ejercer un control territorial en la zona, claramente en oposición al derecho adquirido por las comunidades negras en la ley 70 de 1993; sin embargo, guerrillas como las FARC, más allá de ir en contra de la titulación colectiva lo que buscaban era "extenderse y consolidarse hacia su núcleo de influencia o periférico y progresivamente llegar incluso hasta las zonas de frontera (como el Pacífico), donde su presencia era más débil o nula" (Almario, 2003, p. 228), razón por la cual las circunstancias y el contexto hicieron que el conflicto se extendiera hasta esta zona, obstaculizando el proceso de titulación y propiciando el fenómeno masivo del desplazamiento ${ }^{5}$.

En cuanto al fenómeno paramilitar, Agudelo (2005) señala que, aun cuando en el año de 1996 las acciones de los paramilitares y de la fuerza pública logran un repliegue de la guerrilla en el Urabá antioqueño, será hasta el año de 1997 (luego de la toma de las poblaciones de Vigía del Fuerte y Bellavista) que el fenómeno paramilitar se intensifique en el Medio Atrato (pp. 216-217). Es así como un trabajo colectivo de las comunidades afrocolombianas e indígenas, apoyado por MISEREOR, establece cuatro momentos en la implantación del paramilitarismo en la región del Pacífico:

\footnotetext{
Para Arturo Escobar (2005a) los factores principales que las organizaciones negras asocian al desplazamiento de su comunidad son: "la realización de grandes proyectos de desarrollo en detrimento de los bosques y las explotaciones agrarias locales (por ejemplo, el proyecto del canal interoceánico y la espectacular ampliación de los límites de las plantaciones de palma aceitera africana en la zona de Tumaco), el conflicto armado propiamente dicho, la existencia de ricos recursos naturales (oro, madera y sitios ideales para el turismo), y la propagación de cultivos ilícitos en determinadas áreas ( p. 53). Factores que de diferente manera se refieren a la presencia de grupos al margen de la ley en la región.
} 
el terror, la consolidación militar, el trabajo comunitario y el dominio real de un territorio.

Con la llegada de las autodefensas a la región, se marca el primer momento de la implantación del fenómeno paramilitar. Este momento se caracterizó por el "terror" que este grupo armado produjo dentro de la población civil a través de la quema de poblados, masacres, torturas y descuartizamientos con motosierras. Entre el año 1996 y el año 2001, fue persistente la escalada de la violencia en el Medio Atrato, en el Carmen de Atrato, en Quibdó, en Bojayá, en Vigía del Fuerte, en Murindó, en Carmen del Darién y en las cuencas de los ríos Jiguamiandó y Curvaradó; sin contar otras regiones del Cauca y Nariño (Flórez \& Millán, 2007). Es de anotar que la consecuencia evidente del terror fue el desplazamiento masivo que en muchos casos se concentró en las cabeceras municipales, y en otros ocasionó actos de resistencia civil como la que se produjo en el año 1997, cuando 106 familias de Santafé de Churima, Remacho, Cuatro Tapas y Camelia y el río Jiguamiandó decidieron internarse en el monte y autodenominarse "Los sin nombre y olvidados de la patria” (Flórez \& Millán, 2007, p. 133).

En un segundo momento, luego del "terror" vivido por los habitantes del Pacífico se produce la "consolidación militar" del proyecto paramilitar. Consolidación que se produce como consecuencia de la penetración de las estructuras sociales, políticas y económicas. No se debe olvidar que las autodefensas empiezan a cobrar tributos a los comerciantes, a ejercer presión sobre los candidatos y políticos de turno y a comprar tierras baratas, producto del abandono de campesinos y moradores (Flórez \& Millán, 2007, p. 136). Es importante agregar que para la época, diferentes organizaciones sociales y eclesiásticas ya denunciaban la estrategia paramilitar y la imposición del terror para la implantación de proyectos económicos en la región.

En este orden de ideas, el tercer momento de la implantación del proyecto paramilitar se refiere al "trabajo comunitario" que las autodefensas en orden a legitimar su control territorial en la zona empiezan a llevar a cabo con los pobladores de la región. Este trabajo comunitario se da sobre todo en el Chocó, específicamente en el río Atrato y consiste en que:

Los paramilitares están entregando motosierras, impulsando la creación de grupos asociativos de aserradores, ofreciendo el pago de puestos de promotores de salud en las comunidades y dando facilidad a la organización de tiendas 
locales a fin de hacer contrapeso a la red de tiendas comunitarias creada por las organizaciones sociales (Flórez \& Millán, 2007, p. 136).

Pero lo más grave y quizás más relevante en el caso de los consejos comunitarios tiene que ver con el Plan de Alternatividad Social -PASO, propuesto por el bloque Elmer Cárdenas de las autodefensas, pues con este plan "los paramilitares intentan destruir el actual proceso de organización comunitaria de los pueblos indígena y afrocolombiano al crear nuevas organizaciones con reconocimiento legal para amparar desde allí la puesta en marcha de las actividades económicas" (Flórez \& Millán, 2007, p. 137). En este sentido, lo que sostiene el trabajo colectivo apoyado por MISEREOR es que el PASO lo que buscaba era consolidar el proyecto paramilitar en la región, a través de la disputa frontal con las organizaciones étnico-territoriales de los indígenas y los afrocolombianos. Disputa que se dio a través de dos vías: una de carácter coercitivo, y que buscó a través de presiones vincular a los campesinos en los proyectos productivos; y otra, de carácter positivo, que buscó a través de dadivas venderles el proyecto a los pobladores y a todos aquellos que antes habían sido desplazados por la violencia.

Así es como se llega, finalmente, al cuarto momento de la implantación del proyecto paramilitar que, en palabras de Flórez y Millán (2007), hace referencia al "dominio real del territorio". Dominio que se produce como resultado de la asimilación de este fenómeno dentro de los pobladores de la región, de forma tal que al no ser necesaria la violencia sistemática, comienzan a bajar los índices de criminalidad, la oposición empieza a desaparecer y el proyecto político se consolida. Pero, a pesar de que es coherente el proceso que plantean los autores mencionados, es importante anotar que el trabajo fue publicado en el año 2007 y por ende muestra la realidad social y política del primer periodo de Álvaro Uribe. En consecuencia, siguiendo a los autores se puede afirmar que en el Pacífico no se pudo consolidar esta fase, como por ejemplo sí se logró en Cesar, Magdalena y Córdoba (Flórez \& Millán, 2007). Quizás la razón por la que no se pudo consolidar este proyecto tenga que ver con la organización comunitaria de las comunidades indígenas y afrocolombianas, que a través de las figuras del resguardo y el consejo comunitario pudieron hacerle frente a la violencia sistemática del paramilitarismo.

Sin embargo, aunque se afirma que las organizaciones comunitarias le hicieron frente al fenómeno paramilitar, no se debe dejar de lado los impactos 
de la violencia sobre el proceso, pues no hay que olvidar que el conflicto se agudizó en simultaneidad con el reconocimiento étnico-territorial de las comunidades negras. En este sentido, William Villa (2004) afirma que la guerra en el Pacífico tuvo consecuencias en dos niveles: "el primero se relaciona con lo local, al impedir el real fortalecimiento de los consejos comunitarios; el segundo, al contribuir a la fragmentación del movimiento social de comunidades negras” (p. 336). Dicho esto, es posible agregar que aún cuando el proyecto paramilitar no se consolidó en el Pacífico, sí provocó enormes tropiezos en el proceso organizativo y ocasionó cicatrices difíciles de borrar en los pobladores de la región.

Para Ulrich Oslender este proceso simultáneo de violencia y organización comunitaria en el marco del territorio-región ${ }^{6}$ de las comunidades negras puede ser dilucidado a través del concepto de "geografías de terror". A juicio del autor, este concepto asocia fenómenos geográficos con el terror y el terrorismo a través de seis variables: en primer lugar, "la transformación de ciertos espacios en paisajes de miedo" en relación con las huellas dejadas por los agentes del terror, tales como la destrucción de casas y las paredes marcadas con grafitis; segundo, "los cambios abruptos en las prácticas espaciales rutinarias", manifiestas en las restricciones explícitas o implícitas que los actores armados imponen a la población; tercero, "los cambios radicales en el sentido de lugar" que hacen que el hombre del Pacífico perciba y sienta de manera diferente su territorio, como resultado de la violencia; cuarto, "los procesos de des-territorialización" producto de la apropiación del territorio a través de amenazas y masacres; quinto, "los movimientos físicos en el espacio causados por el contexto de terror", en relación con el desplazamiento masivo; y finalmente, "las estrategias espaciales de resistencia", que hacen referencia a las formas concretas de movilización social en defensa del territorio (Oslender, 2004, pp. 40-44).

Para las Comunidades Negras de la Cuenca del Pacífico el territorio tiene una relación inherente con la cultura y la tradición de su pueblo, pues como lo sostiene el Proceso de Comunidades Negras -PCN (2008) "El desarrollo y la re-creación de nuestra visión cultural requieren como espacio vital el territorio. No podremos SER, si no tenemos el espacio para vivir de acuerdo a lo que pensamos y queremos como forma de vida. De ahí que nuestra visión de territorio sea la visión de hábitat, es decir, el espacio donde el hombre negro y la mujer negra desarrollan colectivamente su SER, en armonía con la naturaleza (p. 4). 
En el planteamiento de Oslender no se hace referencia explícita a los consejos comunitarios como mecanismos de resistencia civil en orden a defender el territorio, sino que más bien se habla de la posibilidad de organizar redes de colaboración entre los distintos poblados que permitan reaccionar colectivamente frente al accionar bélico de los grupos armados. A juicio del autor estas redes se deben articular a las lógicas de los ríos, pues no se debe olvidar que su trabajo se concentra en "espacializar la resistencia", demostrando que los procesos organizativos de las comunidades negras obedecen a la geografía del lugar.

Por tanto, en orden a concluir este apartado es preciso afirmar que aun cuando se han producido diferentes conflictos producto de la aprobación de la ley 70 de 1993 y la titulación colectiva de tierras, quizás el conflicto armado ha sido el que ha producido más consecuencias sobre el proceso organizativo, pues ha contribuido a fortalecer internamente los consejos de cara a responder a la acción bélica de los actores armados, pero también ha truncado los procesos, obligando a los moradores y legítimos habitantes del Pacífico a desplazarse hacia otras regiones.

\section{Los proyectos de desarrollo rural y los intereses corporativos}

Hablar de desarrollo en una región como el Pacífico reclama por necesidad una referencia al texto clásico de Arturo Escobar La invención del Tercer Mundo, Construcción y deconstrucción del desarrollo (1996). En este documento el académico colombiano se propone demostrar que el desarrollo debe ser visto como un régimen de representación, inventado en la segunda posguerra como una estrategia para resolver los problemas de las áreas subdesarrolladas del globo, en conformidad con los dictados del llamado primer mundo, sin embargo, como él mismo agrega "el discurso y la estrategia del desarrollo produjeron lo contrario: miseria y subdesarrollo masivos, explotación y opresión sin nombre" (Escobar, 1996, p. 21). En consecuencia, este apartado buscará atender a los trabajos que se han ocupado de los proyectos de desarrollo formal e informal en la región.

En este sentido, de acuerdo con lo anterior, Carlos Agudelo (2005) sostiene que se han dado dos vías para la institucionalización del desarrollo en el Pacífico: por un lado, aquellas que han estado adscritas a entes del gobierno, como por ejemplo las Corporaciones Autónomas Regionales -CAR o el De- 
partamento Nacional de Planeación -DNP, que a su vez han contado con el apoyo de instituciones internacionales como el Banco Mundial -BM y el Programa de Naciones Unidas para el Desarrollo -PNUD; y por otro, aquellas que han sido promovidas de manera independiente por organismos no gubernamentales -ONG. De esta manera, buscando atender a un concepto crítico de desarrollo, será preciso centrar la atención en la primera vía, sin dejar de lado por supuesto aquellas iniciativas adelantadas por las ONG.

Dicho lo anterior, es importante mencionar siguiendo a Agudelo, que todas estas iniciativas de desarrollo son producto de las influencias del discurso global sobre la modernización; el reclamo recurrente de sectores de la élite política y de la Iglesia, y las catástrofes naturales. Todos factores que llevaron a despertar las alarmas del desarrollo en el litoral Pacífico, donde se evidenciaban grandes rezagos con respecto a las demás regiones del país (Agudelo, 2005). Es así como se presentan a partir de los años setenta diferentes proyectos entre los que vale la pena mencionar: el Plan Integral de Desarrollo para la Costa Pacífica -Plaidecop ${ }^{7}$; el Plan Pacífico; el Proyecto Biopacífico; y la Agenda Pacífico XXI.

El Plaidecop buscaba articular todos los proyectos sectoriales que se desarrollaban en la región con el fin de encontrar formas más eficaces de explotar los recursos forestales, pesqueros y flúvio-mineros. Igualmente, contemplaba dentro de sus propósitos mejorar el nivel de vida y proporcionar bienestar a las poblaciones de la costa Pacífica (Agudelo, 2005). Los componentes básicos del plan eran:

1) Elaborar estudios y diagnósticos previos a la implementación de los proyectos del plan. 2) Desarrollar proyectos de infraestructura tales como construcción de nuevas vías de comunicación interna y con el exterior de la región, muelles, ampliación de cobertura eléctrica y de comunicaciones. 3) estimular la producción minera, pesquera y forestal tanto industrial como artesanal. 4) Atender el área social con proyectos de salud, saneamiento ambiental, educación y vivienda (p. 77).

No obstante, aún cuando lo anterior reclama una enorme voluntad política por los recursos humanos y económicos necesarios para llevar a cabo el plan, el problema no es de voluntad, pues el mismo Belisario Betancur

Flórez y Millán utilizan siglas diferentes para hacer referencia al mismo plan, mientras que Agudelo se refiere al Plaidecop, los primeros hablan del Pladeicop. 
manifiesta su interés de sentar las bases para llevar a cabo una política en el Pacífico y elaborar un plan de desarrollo. El problema real tiene que ver con el hecho de que convertir a éste en una entidad desarrollable, implica intervenciones sobre la población en las que los expertos y técnicos sobreponen su conocimiento a las experiencias cotidianas, la cultura y las tradiciones de la población afrodescendiente e indígena. Modelo desarrollista que ha alterado las condiciones de vida de estas poblaciones, a través de la reconfiguración del territorio: pasando de un modelo de autosubsistencia, a un modelo que somete a las comunidades a servir a procesos de acumulación económica (Flórez \& Millán, 2007).

Ahora bien, en el año de 1992 culmina la primera fase del Plaidecop y a pesar de que se propone una segunda fase, el gobierno nacional decide desmontarlo y sustituirlo por el Plan Pacífico. Un plan que a juicio de Agudelo, le da continuidad a algunos de los proyectos del Plaidecop, pero que centra su atención en el desarrollo institucional a través de actividades productivas sostenibles, de saneamiento básico, salud y educación. Igualmente, cabe anotar que las políticas del Plan Pacífico se ajustan a las orientaciones de los organismos internacionales de desarrollo; sobre todo en materia de protección del medio ambiente y racionalización de los recursos naturales. En este sentido, los objetivos estratégicos del plan eran:

1) Incrementar la capacidad de gestión de los actores del programa (administradores municipales; gobernación del Chocó; organizaciones de base, de Comunidades Negras, comunidades indígenas; líderes políticos y comunitarios). 2) Mejorar la calidad de cobertura de servicios básicos: salud, educación y saneamiento básico y desarrollar alternativas productivas sustentables que mejoren los ingresos de la población (Agudelo, 2005, p. 78).

El plan financiado con créditos del Banco Interamericano de Desarrollo se aprueba el 27 de julio de 1994 y empieza a ejecutarse en junio de 1995 después del primer desembolso ${ }^{8}$. Es importante agregar, que dado el carácter excluyente del Plaidecop, este plan se propone respetar la biodiversidad social, étnica, cultural y de género; promoviendo el buen entendimiento entre

De acuerdo con Flórez y Millán (2007) el 8 de septiembre de 1993 se autoriza al gobierno nacional para "contraer créditos externos con el BID por US\$650 millones. Otros recursos del plan provienen del Banco Interamericano de Reconstrucción y Fomento (BIRD) por US \$22 millones y US \$260 millones de contrapartida nacional y de cooperación internacional" ( p. 104). 
los gobiernos locales, la comunidad y las instituciones públicas y privadas (Flórez \& Millán, 2007). Pero a pesar de los avances en materia de participación ciudadana, Agudelo sostiene que la experiencia en el plano local específicamente en Guapi, muestra las limitaciones de estos mecanismos de consulta (Agudelo, 2005). Sin embargo, teniendo en cuenta que el plan se propone estrategias de conservación del medio ambiente y protección de los recursos naturales desde la perspectiva del desarrollo sostenible, se podría pensar que muestra cambios significativos con respecto al Plaidecop, pero como lo anota Escobar (2010) "el Plan Pacífico continuó teniendo una orientación predominantemente economicista, incluso si antes de finales de los noventa ya era expresada en términos de "capital social", en el que los planificadores incluían capitales institucionales, infraestructurales y ambientales" ( p. 183).

En este contexto, surge el proyecto Biopacífico con el propósito explícito de conservar la biodiversidad de la región. Vale la pena anotar, siguiendo a Escobar (2010), que este proyecto es mucho menos ambicioso que el Plan Pacífico pues solamente en términos presupuestales le destinan 6 millones de dólares en contraste con los 250 millones del pacífico. Para Agudelo (2005) es importante enfatizar que aunque en un comienzo la participación de las organizaciones se limitó a consultas sobre estrategias y contenidos del proyecto, "con la presión de las organizaciones étnicas y la aprobación de la cooperación suiza se crea un mecanismo de participación llamado 'el comité ampliado' en el que la participación comunitaria [cobra] real importancia" (p. 81). Es así como, las organizaciones comunitarias comienzan a hacerse partícipes del desarrollo, pasando de un período de total exclusión (Plaidecop) en el que eran consideradas como bárbaras o atrasadas, a un período en el que van ser consideradas como partes en la negociación y en el diálogo.

Pero solo será hasta la Agenda Pacífico XXI que se concretará la coordinación efectiva de actores oficiales y organizaciones sociales, pues allí participarán activamente en el diseño de la agenda cuatro actores principales: los grupos étnicos negros e indígenas; los agentes del Estado representados en las gobernaciones departamentales, las alcaldías y los ministerios; la academia a través de las universidades públicas y privadas; y los gremios productivos e industriales interesados en la zona. Esta identificación de los actores deja entrever el interés por construir políticas de desarrollo en las que la comunidad 
participe de manera activa sin ser únicamente el objeto de las mismas. Es así como la Agenda XXI se propone como objetivo fundamental:

La formulación de planes, políticas y programas a largo plazo mediante un amplio proceso de participación local, que permita el reconocimiento de la realidad étnica, cultural, social, económica y ambiental del Pacífico colombiano, y que orienten su desarrollo y su articulación al progreso de la nación, ello en un plazo de 20 años. A este aspecto se une la formulación y la implementación de una política ambiental y un plan de desarrollo para la acción regional hacia el próximo milenio, con un proceso de reflexión y de acción política, motivando esfuerzos institucionales que potencien proyectos de vida autónomos en las comunidades (Flórez \& Millán, 2007, p. 106).

En este sentido, siguiendo a Escobar (2010), son dos las explicaciones que se pueden dar para entender el cambio en la orientación de la política. De un lado, se puede argüir en favor de la cooptación que el Estado hizo de los movimientos sociales en un contexto pluriétnico y multicultural, posterior a la Constitución de 1991; de otro lado, se puede hablar más bien de las presiones que sobre el Estado ejercieron los movimientos sociales, de cara a participar activamente de los asuntos que les competen. Sea cual fuere la explicación, lo cierto es que la agenda reconoció las organizaciones étnico-territoriales como un potencial de la región, que desde el punto de vista de los consejos comunitarios es visto como un avance significativo en el camino hacia un modelo de posdesarrollo en el que se dejen de lado esquemas de desarrollo modernizantes y excluyentes.

Siguiendo entonces con las vías para la institucionalización del desarrollo de las que habla Carlos Agudelo, es preciso hacer referencia a las iniciativas que en la región han venido adelantando diferentes ONG. Al respecto el autor colombiano presenta tres ejemplos de instituciones, que de forma diferente, han implementado políticas de desarrollo y han contribuido al trabajo comunitario en la región. En primer lugar está el Plan Padrinos que consiste esencialmente en crear vínculos entre un niño de un hogar beneficiario y un donante residente de un país desarrollado, con el propósito de que este último haga una donación periódica mínima anual de US $\$ 200$. Estas a su vez son destinadas a la salud, la educación, el hábitat y la organización comunitaria. El plan se desarrolló en Colombia, sobre todo en Buenaventura, permitiendo proveer a las comunidades de ciertos servicios que el Estado hasta ese momento no había garantizado. En segundo lugar, 
está la ONG Habla Scribe, conformada por profesionales y estudiantes de la Universidad del Valle con el propósito de capacitar a las comunidades en comunicación y desarrollar actividades de educación popular. En tercer lugar está la Fundación para la Educación Superior (FES) que a través de los excedentes de sus actividades comerciales apoyó proyectos de salud, medio ambiente y desarrollo económico y social (Agudelo, 2005).

En este orden de ideas, luego de atender a las vías institucionales del desarrollo de las que habla Agudelo, es preciso hacer referencia al trabajo que Eduardo Restrepo adelantó en torno al Proyecto de Desarrollo Integral Agrícola Rural -DIAR. Un proyecto que se remonta al año de 1975 con la firma de un acuerdo entre los gobiernos de Colombia y Holanda y en el que se buscaba cooperar en los sectores de infraestructura y salud. Quizás uno de los aspectos más destacados de este proyecto tiene que ver con la noción de desarrollo, pues siguiendo a Restrepo, este concepto no se circunscribe a lo productivo, sino que hace referencia a una perspectiva más holística en la que se incluye también lo institucional y lo educativo. A pesar de que esta visión del desarrollo parece innovadora es la misma que en el nivel nacional se presenta a través del Programa de Desarrollo Rural Integrado -DRI y en nivel regional se presenta a través del Plaidecop -anteriormente expuesto(Restrepo, 2010).

El proyecto DIAR resulta importante por dos razones, la primera porque se desarrolla en el Medio Atrato y la segunda porque se constituye en el antecedente inmediato de los consejos comunitarios. En cuanto a lo primero, vale la pena señalar que el proyecto polariza a la población y muestra posiciones encontradas entre quienes lo defienden y quienes lo rechazan; hecho que para Restrepo expresa una ambigüedad, pues mientras se plantean fuertes críticas debido al despilfarro de recursos en proyectos inconclusos, los relatos que en su mayoría recopila el antropólogo colombiano en su trabajo de campo dejan ver una defensa a ultranza de la iniciativa, arguyendo que éste "había sido el único proyecto que había traído beneficios a las poblaciones locales" (Restrepo, 2010, p. 10).

Pues bien, las razones probables para que el proyecto hubiera despertado tan asiduas críticas quizás tienen que ver con el hecho de que el proyecto en términos generales fue un fracaso; debido a que el propósito de impulsar el desarrollo no se logró. Antes bien, lo que quedan son ruinas de una infraes- 
tructura que en su momento fue señal de progreso. Lo más contundente del fracaso del DIAR tiene que ver con el desconocimiento de la cultura y las tradiciones de las comunidades, pues el proyecto en su intento de cambiar las prácticas de autoabastecimiento por prácticas de acumulación, sembró en los campesinos una dependencia en el mercado que a la postre terminó por dejarlos sin el propio sustento.

Por el contrario, quienes arguyen que el proyecto trajo cosas buenas pueden fundar sus razones bien sea en el hecho de que el DIAR permitió el flujo de recursos financieros directos e indirectos para la financiación del proceso organizativo de las comunidades negras ${ }^{9}$, o en razón a que contribuyó de manera significativa a gestar las condiciones de posibilidad de la representación de las comunidades negras como un grupo étnico. Lo cierto es que siguiendo a Restrepo, los grandes logros del proyecto fueron resultado de los efectos no intencionados, a saber:

(1) Su contribución fundamental a generar las condiciones de posibilidad para el movimiento social de mayor importancia y con mayor trascendencia para las poblaciones afrodescendientes no solo en la región del Medio Atrato y del Pacífico en general, sino en Colombia y otros países como Ecuador. (2) Su significado en la formación de profesionales y líderes chocoanos que han estado participando en instituciones y programas gubernamentales, en organizaciones de base y en organizaciones no gubernamentales, algunos de ellos queriendo replicar la metodología aprendida en el DIAR. (3) Su contribución a la creación de un imaginario y una práctica entre las poblaciones locales y de la región de que la gestión de lo social se realiza desde la lógica de la formulación y ejecución de proyectos (Restrepo, 2010, pp. 112-113).

Dicho esto, solo resta agregar que el proyecto DIAR configuró en el imaginario colectivo de las comunidades negras la idea de los derechos territoriales y de la etnicidad. Un constructo colectivo que, a partir del acuerdo de Buchadó animó las banderas del movimiento afrocolombiano que en vista del reconocimiento local hizo perentoria la movilización en defensa de sus derechos étnico-territoriales en el nivel nacional. En otras palabras, el DIAR no solo creó la conciencia de los derechos de las comunidades, sino que permitió la legitimación local de los mismos y la movilización nacional

$\mathrm{Al}$ respecto se puede agregar que el DIAR trajo, como beneficios concretos, el incremento de dinero circulante en la región y el empleo remunerado (Restrepo, 2010). 
en procura de su legalización, todos procesos que concluyeron en la presión sobre la Asamblea Nacional Constituyente y la consecuente aprobación del artículo 55 -del que se hablará más adelante-.

Luego de contemplar las políticas de desarrollo adelantadas en la región resulta pertinente atender al problema que enfrentan los consejos comunitarios en relación con los intereses privados de las empresas en la región (Rúa, 2004). Intereses que a juicio de Agier y Hoffmann (1999), pueden ser comprendidos si se tiene en cuenta que:

Desde hace más de un siglo diversos agentes privados han invertido en el Pacífico para obtener beneficios a partir de la extracción de los recursos naturales (caucho, tagua, madera de mangle, maderas preciosas, oro y, desde hace unos veinte años, madera para la construcción y palmito) y de la instalación de plantaciones agro-industriales (palma africana). En general, los empresarios tratan con intermediarios locales que imponen precios y condiciones a los habitantes agricultores, quienes están siempre en situación de desventaja si se tiene en cuenta la falta crónica de dinero en efectivo en estas regiones alejadas de los centros comerciales (p. 53).

Pero lo más grave de esta situación tiene que ver con el contexto posterior a la instauración de la ley 70 de 1993. De manera que si se tiene en cuenta que a partir de este momento las comunidades afrodescendientes pasaron a tener derechos étnico-territoriales, y por ende pasaron a ser reconocidas como las legítimas propietarias de las tierras de la cuenca del Pacífico, además de que las empresas privadas interesadas en explotar los recursos de la región, debían obtener un acuerdo previo con los consejos comunitarios. Resulta inverosímil pensar que estas empresas se adecuan al nuevo marco normativo y en orden a conseguir sus propósitos de explotación y acumulación, se dan a la tarea de constituir consejos y preparar la vía para la negociación. Algo que en palabras de Oslender (2008), conduce a fenómenos como el de UNICOSTA

UNICOSTA fue el primer consejo comunitario al que se le otorgaron tierras colectivas en el departamento de Nariño. Ello se debió principalmente a que había sido activamente promovido por una compañía -Alimentos Enlatados del Pacífico (ALENPAG)- que durante más de diecisiete años había explotado la palma de Naidí en la zona [...] antes de la Ley 70, ALENPAC necesitaba un permiso para la explotación de los palmitos, que era expedido por la Corporación Autónoma Regional de Desarrollo (CORPONARIÑO). Sin embargo, con la nueva legislación, estos procedimientos han cambiado. Ahora 
CORPONARIÑO otorga un permiso de explotación al consejo comunitario y éste contrata luego con la compañía (p. 224).

En este sentido, el problema planteado por Agier y Hoffman (1999) y ejemplificado por Oslender (2008), pone de presente el hecho de que la ley 70 de 1993 no solo puede ser interpretada como un instrumento legal en defensa de los derechos étnico-territoriales de las comunidades negras, sino también como un recurso idóneo de corporaciones y empresas, que en aras de aprovechar la vulnerabilidad económica de los campesinos pueden llevar a cabo inversiones productivas en espacios rentables a través de la financiación y cooptación de los respectivos consejos comunitarios. En otras palabras, la ley 70 habilita a los grandes capitales a explotar el territorio sin necesidad de solicitar permisos ni comprar tierras.

Centrando la atención ahora en los documentos CONPES y en las políticas públicas destinadas a la población afrodescendiente durante el período del presidente Álvaro Uribe, es posible afirmar que a partir de la Constitución de 1991 se ha dado una mayor visibilización de la región Pacífica y por ende una importante proliferación de políticas destinadas a reducir la brecha en las condiciones de vida de la comunidad negra. Es así que, entre el año 1992 y el año 2010 el Consejo Nacional de Política Económica y Social -CONPES ha aprobado los siguientes documentos:

Tabla 1. Documentos CONPES para población afrocolombiana del Pacífico (1992-2010)

\begin{tabular}{cl}
\multicolumn{1}{c}{$\begin{array}{c}\text { Documento } \\
\text { CONPES }\end{array}$} & \multicolumn{1}{c}{ Descripción } \\
Conpes 2589 de 1992 & $\begin{array}{l}\text { Programa BID - Plan Pacífico: una Nueva Estrategia de } \\
\text { Desarrollo Sostenible para la Costa Pacífica Colombiana. } \\
\text { PND: La Revolución Pacífica. }\end{array}$ \\
\hline Conpes 2892 de 1996 & $\begin{array}{l}\text { Plan de Desarrollo Integral del Alto Patía. PND: el Salto } \\
\text { Social. }\end{array}$ \\
Conpes 2909 de 1997 & $\begin{array}{l}\text { Programa de Apoyo para el Desarrollo y Reconocimiento } \\
\text { Étnico de las Comunidades Negras. PND: el Salto Social. }\end{array}$ \\
Conpes 3169 de 2002 & $\begin{array}{l}\text { Política para la Población Afrocolombiana. PND: cambio } \\
\text { para Construir la Paz. }\end{array}$ \\
\hline Conpes3180 de 2002 & $\begin{array}{l}\text { Programa para la Reconstrucción y Desarrollo Sostenible } \\
\text { del Urabá Antioqueño y Chocoano y Bajo y Medio Atrato. } \\
\text { PND: cambio para construir la paz. }\end{array}$ \\
\hline
\end{tabular}


Documento GONPES

Conpes 3310 de 2004

Conpes 3410 de 2006

Conpes 3491 de 2007

Conpes 3553 de 2008

Conpes 3660 de 2010

\section{Descripción}

Política de Acción Afirmativa para la población negra o Afrocolombiana.

Política de Estado para mejorar las condiciones de vida de la población de Buenaventura.

Política de Estado para el Pacífico Colombiano.

Política de Promoción Social y Económica para el departamento de Chocó.

Política para promover la igualdad de oportunidades para la población negra, afrocolombiana, palenquera y raizal.

Fuente: Autor con base en información extraída del documento Conpes 3660 de 2010.

Teniendo en cuenta la Tabla 1, no solo se puede afirmar que la población negra en general y los habitantes del Pacifico en particular, han cobrado relevancia para el Gobierno Nacional desde el reconocimiento de los derechos étnicos en la Constitución de 1991 y en la ley 70 de 1993; sino que además es posible sostener que en los últimos años se han producido un gran número de políticas, específicamente en el período comprendido entre el año 2002 y el año 2010. Resulta paradójico pensar que en simultaneidad con la agudización del conflicto y las presiones corporativas sobre las comunidades negras se da precisamente el reconocimiento de los derechos étnicos, y además la mayor concentración de políticas públicas destinadas a esta población vulnerable. Quizás puede quedar para un trabajo posterior el examen minucioso de estos documentos CONPES de cara a analizar sí en algún sentido cooptan los intereses empresariales. Por ahora, más allá que emprender esta búsqueda, lo que interesa es mostrar que existe un reconocimiento étnico de las comunidades que bien puede ser demostrado en el CONPES 3660 de 2010, que en conformidad con la ley 70 define el consejo comunitario como una "entidad étnica con personería jurídica conformada por una comunidad negra para administrar el territorio que el Estado les ha reconocido como propiedad colectiva por medio de un título" (CONPES, 2010, p. 11).

En estos términos se puede cerrar este apartado sosteniendo que se han producido varios trabajos en torno al desarrollo del Pacífico y la injerencia del capital; pero hace falta examinar con más detalle las políticas públicas adelantadas por el gobierno -sobre todo en el periodo de Uribe-; pues resulta 
paradójico que por un lado se promueve el desarrollo y se reconocen los derechos étnicos, y por otro los intereses empresariales y los actores armados presionan a la población para usufructuar su tierra. Lo cierto es que este asunto será dejado de lado en lo que sigue no sin antes alertar sobre este campo de estudio agregando además que los trabajos aquí examinados dejan de manifiesto que el rol de los consejos comunitarios ha venido siendo esencial en la transformación de la idea del desarrollo en la región, pero al mismo tiempo ha suscitado incógnitas en torno al uso instrumental que empresas como ALENPAC han llevado a cabo en el Pacífico Nariñense.

\section{La etnización de las comunidades negras}

Son múltiples los trabajos que se han desarrollado en torno a las comunidades negras desde la perspectiva de la etnicidad. Con gran seguridad esta numeraria producción académica tiene que ver con el hecho de que a partir de la Constitución de 1991 con el reconocimiento de la nación pluriétnica y multicultural se da un vuelco radical en la forma de entender a los afrodescendientes. En este sentido, es preciso afirmar que Eduardo Restrepo (2005) ha sido uno de los autores que ha trabajado con más ahínco el tema, el antropólogo colombiano se propone demostrar que el reconocimiento como grupo étnico de la comunidad negra en nuestro país no fue algo gratuito, sino que respondió más bien a un complejo e intrincado proceso desarrollado a lo largo del último cuarto del siglo XX.

La primera fase del proceso de etnización se produjo a mediados de la década de los ochenta, en donde confluyeron dos factores que motivaron la creación de la Asociación Campesina Integral del Atrato. De un lado, la creciente amenaza de despojo de las tierras de la cuenca del Pacífico, a manos de compañías extranjeras con interés por explotar los recursos forestales y mineros de la región ${ }^{10}$; y de otro , la presencia de misiones religiosas con interés en ayudar a las comunidades a crear organizaciones de base, con sensibilidad etnicista y orientadas a defender el territorio ancestralmente habitado (Restrepo, 2005).

10 No se debe olvidar, como ya se mencionó anteriormente, que los territorios de la cuenca del Pacífico eran considerados, de acuerdo con la ley 2 de 1959, "zonas baldías". 
La segunda fase del proceso en cuestión se instaura con la Constitución de 1991, en donde la lucha por el reconocimiento étnico y la defensa del territorio se lleva del escenario local del Acuerdo de Buchadó ${ }^{11}$, a la Asamblea Nacional Constituyente -ANC y la correspondiente aprobación del artículo 55. Es importante enfatizar que en ese momento, como en ningún otro de la historia reciente la comunidad afrocolombiana se unió con un único propósito común: el reconocimiento de sus derechos étnico-territoriales. Muestra de la presión constante que se ejerció sobre la ANG fue la campaña del "telegrama negro" y la toma pacífica de entidades públicas en diferentes ciudades del país (Restrepo, 2005).

En cuanto a la tercera y cuarta fase, de las que habla Restrepo es factible pensar en la paradoja de la que ya antes se había hablado, pues por una parte se hace referencia al período que inaugura la ley 70 de 1993 y que culmina con el decreto 1745 de 1995 -del que se hablará más adelante-; y por otra se habla del período marcado por la agudización de las dinámicas de la guerra, el avance de los cultivos ilícitos y las presiones de la empresa privada. Dos procesos que definitivamente chocan y confrontan la realidad del hombre del Pacífico, pero que al final de cuentas hacen que a pesar del desplazamiento y las "geografías del terror" de las que habla Oslender, sea posible pensar en una "contra-revolución étnica” (Restrepo, 2005).

Ciertamente, el proceso de etnización que plantea Restrepo parece plausible, pero como él mismo inquiere en otro de sus trabajos es preciso preguntarse por los actores que hicieron posible este proceso; en sus palabras, el propósito de este artículo publicado en el año 2002 es "describir el contexto, las mediaciones y los actores que hicieron posible la reciente emergencia de la 'comunidad negra' como grupo étnico para dicha región”' (Restrepo, 2002, p. 32). En este sentido, se afirma que las misiones religiosas y el proyecto DIAR se constituyen en los principales actores en la movilización de las poblaciones de la cuenca del Pacífico. En cuanto a la iglesia, se anota que ésta fue central

El acuerdo de Buchadó (1987) representa uno de los mayores avances en el proceso de la etnizacion de las comunidades negras en Colombia, en la medida que fue el primer documento con participación oficial en el que se reconoció "el derecho que asiste a las comunidades campesinas del Medio Atrato sobre los territorios comunitarios que ancestralmente han ocupado" (numeral 1). No obstante, el gran rezago de este acuerdo era el carácter local, por un lado, y por otro, la insuficiente validez jurídica en relación con el reconocimiento de la propiedad. 
en la emergencia de las primeras experiencias organizativas del Chocó; mientras que el Proyecto DIAR desde las investigaciones que lleva a cabo sienta las bases del proceso organizativo en la medida que reivindica las prácticas agrícolas de las comunidades, arguyendo que "los campesinos negros del Atrato aparecen como los artífices de un sistema productivo altamente adaptado para explotar de manera diferencial y multiopcional diversos recursos según los disímiles ecosistemas y la cambiante oferta ambiental" (Restrepo, 2002, p. 40).

Así las cosas, el artículo 55 puede ser considerado como el catalizador de la etnización del pueblo negro en Colombia. Si se tiene en cuenta que la ANC crea las condiciones para la negociación de una ley en la que se avale la posesión no titulada de la tierra, es razonable pensar que a partir de estas circunstancias es que se logra coordinar a la disgregada población negra. No es para menos, teniendo en cuenta que por un lado se sentían las presiones del capital foráneo y el narcotráfico; y por otro, se asistía a un momento histórico, en la medida que estaba en manos de la comunidad hacerse partícipe de la formulación de esta ley. Además, no está de menos agregar que mientras las comunidades indígenas "fueron objeto explícito de disposiciones territoriales, económicas, educativas y político-administrativas, las poblaciones negras solo encuentran en un artículo transitorio las posibilidades de materializar sus derechos específicos" (Restrepo, 2002, p. 38).

En este contexto, cobra relevancia el trabajo de Odile Hoffmann en el que muestra desde otra perspectiva la movilización negra. La autora contextualiza el proceso organizativo en el marco de las reformas llevadas a cabo en los años ochenta, a saber: la apertura económica, la descentralización y la democratización. A su juicio:

La movilización popular suscita, a la vez que se fortalece con ella, la emergencia de actores locales apoyados por las ONG (Plan Padrino), los programas de desarrollo que por estos años se implementan en el Pacífico -en Tumaco es sobre todo la CVC- y la Iglesia Católica que inicia una línea de pastoral negra en los años 1980. Sean masivas o puntuales, a veces violentas, estas expresiones populares participan de una misma reivindicación de protagonismo frente a un Estado ausente y un capital cuyas lógicas y exigencias invaden todas las esferas de la vida regional (Hoffmann, 2003, p. 13)

Quizás, el mayor vacío de este trabajo tiene que ver con la conceptualización, pues el desarrollo que se hace del concepto de etnicidad es pobre, por no decir nulo, sin embargo, a pesar de este vacío se puede hallar un actor 
no trabajado suficientemente por Restrepo (2002) y que también cumple un papel indispensable en el proceso de etnización. Se hace referencia al Proceso de Comunidades Negras -PNC; que como Hoffmann (2003) lo anota, acompañará a las organizaciones de base a constituir Consejos Comunitarios y promover la titulación de territorios colectivos.

Ahora bien, teniendo en cuenta el vacío conceptual de Hoffmann y volviendo sobre el problema de los conflictos intraétnicos es preciso establecer una distinción entre el concepto de raza y el concepto de etnia. No hay que olvidar que la titulación colectiva trae consigo un problema inmenso en términos de la inclusión y la exclusión de ciertos actores. Específicamente se habla del paisa y del chilapo que a pesar de pertenecer a la comunidad y de tener sus tierras en la zona, en muchos casos es separado del proceso organizativo que adelantan las comunidades negras en razón de su color. Pues bien, para Peter Wade (2000) a pesar de que raza y etnicidad son términos que no tienen referentes fijos, y por ende están circunscritos a un contexto y una historia de las ideas se puede argüir que:

Las identificaciones raciales utilizan aspectos fenotípicos como una clave para la categorización, pero se cree que se transmiten dentro de las generaciones (a través de la sangre); de ahí que sea importante el origen ancestral; de igual manera la etnicidad trata del origen en una geografía cultural en la cual una persona absorbe la cultura de un lugar (casi en la sangre) de las generaciones anteriores (pp. 29-30).

De este modo, el argumento de exclusión a partir de rasgos fenotípicos termina siendo racista antes que étnico, pues busca excluir a un miembro del grupo por sus características físicas, y no por el hecho de que comparta, o no, ciertas prácticas culturales y tradiciones. No en vano afirma Restrepo (2009) en alusión a Stuart Hall que la etnicidad es un concepto asociado a la locación social, que se articula a través de rasgos culturales y que se opone a la raza, en la medida que ésta se asocia sobre todo a prácticas de discriminación por características somáticas.

En este orden de ideas, retomando un trabajo de Odile Hoffmann, luego de precisar la distinción entre raza y etnicidad cobra relevancia el tema del lugar, pues de acuerdo con la ley 70 de 1993 el reconocimiento de la etnicidad está asociado al territorio. En estos términos, para la autora hablar de "territorios étnicos" resulta paradójico en la medida que se asocian desde 
una visión moderna la legitimidad del poder y determinadas porciones de espacio. Es así que, Gupta y Ferguson, citados por ella misma, aducen que se deben atacar dos naturalismos: el primero es la asociación de un grupo culturalmente unitario (tribu o pueblo) a su territorio; y el segundo es la asociación natural de los ciudadanos con los territorios de sus Estados (Hoffmann, 2007, p. 440).

Bajo estas circunstancias, sostiene la autora, que el territorio en la perspectiva posmoderna termina siendo visto como una herramienta al servicio del Estado, que en orden a cumplir con su tarea de ejercer la dominación sobre ciertos colectivos, les asigna un lugar específico y les restringe su libertad. En consecuencia, mientras que esta perspectiva encuentra una clara oposición entre la emancipación y el territorio; las luchas de la población afrodescendiente en Colombia durante la década del noventa sientan las bases de un modelo moderno de emancipación, en el que el territorio étnico es esencial para hacer frente a las décadas de exclusión y marginalización. En este sentido no es que Hoffmann asuma el punto de vista moderno, sino que deja entrever la aparente contradicción que se da en el movimiento negro al asimilar la etnicidad con el territorio.

Empero, este argumento posmoderno deja de lado el reconocimiento étnico que el pueblo negro le da al territorio, pues para los habitantes del Pacífico el espacio es un componente inextricable de su cultura. Para Sergio Mosquera (2009), una prueba de ello es la práctica de la ombligada, según la cual la partera o comadrona introduce en el ombligo del neonato una esencia a través de la cual se le transfieren al recién nacido las energías de otros seres de la naturaleza. Pero la práctica en sí misma no evidencia la importancia del territorio, sino se tiene en cuenta que:

Primero, aquel pedacito de ombligo, que cae o se desprende, es utilizado para sembrar al hijo. Este se entierra en el fogón o en un guayacán de la vivienda para que la persona nunca se ausente por largo tiempo de la casa [...] Segundo, se considera que al séptimo día del nacimiento al infante debe haberle caído o desprendido, el ombligo; de lo contrario es atacado por un mal que le da ese día, denominado mal de los siete días, el cual le puede causar la muerte. Ese mal se repite en los múltiplos de siete hasta llegar a veintiuno, sus manifestaciones son convulsiones, labios morados y continúas segregaciones de baba. Pasada esa prueba se considera que el niño sale del peligro y se considera que vivirá (pp. 46-47). 
Los consejos comunitarios del medio Atrato en la vía del posdesarrollo Hacia un modelo deliberatorio de organización de las comunidades negras

Realmente lo que interesa acá es la primera acepción que presenta Mosquera, pues se cree que al enterrar el ombligo en un "guayacán de la vivienda", o bien, en cualquier tipo de árbol, se creará un vínculo entre el recién nacido y el lugar donde habita, de manera tal que siempre sabrá y se le recordará que allí está enterrado su ombligo. Como lo menciona Carlos Andrés Meza (2010) en referencia a una entrevista hecha a Hipólito Palacios:

[...] cuando los niños nacen, la mayoría acostumbrados a secar el ombligo, y le sembramos una palma de coco o de chontaduro al niño a nombre de él. Ese frutal crece ahí a nombre de ese niño. Cuando él va creciendo, uno le dice: "ve, esta palma de coco es tuya, que te la sembré yo ahí, y ahí está tu ombligo" (p. 231).

Ciertamente este tipo de referencias crean en el hombre del Pacífico una relación inconmensurable con su espacio, pues no se trata de un lugar sin más, sino de un lugar irremplazable, sin par: un lugar en el que se tiene enterrado su ombligo, en el que reposa su centro de gravedad. En consecuencia, se puede afirmar que el territorio sí es constitutivo de la etnicidad de las comunidades negras, sobre todo teniendo en cuenta que es constitutivo de su cultura.

Estas y otras prácticas llevadas a cabo por los sobanderos, los pegahuesos, los veedores de orines y los curanderos -por contar solo algunos ${ }^{12}$ hacen pensar en los consejos comunitarios como una fase en el proceso de etnización de las comunidades negras, pues no se trata de titular territorios como un logro en términos de acumulación y ganancia, sino de titular y organizarse para garantizar el desarrollo de principios culturales, que sin espacio y sin organización seguramente hubieran fenecido frente a los intereses del capital y las presiones del conflicto. Principios que a juicio del PGN se pueden concretar en: la afirmación y reafirmación de ser negros; el derecho a un espacio para ser en términos del territorio; el derecho al ejercicio del ser

12 Carlos Andrés Meza (2010) describe los roles de estos practicantes así: "la partera, o comadrona, se encarga de atender los partos, de curar enfermedades como el pasmo y el mal de nación, o de nacimiento; el pegahuesos tiene como labor curar las fracturas; el veedor de orines conoce las enfermedades y sus orígenes, a través de leer o interpretar la orina del paciente, de acuerdo al color y la densidad; el sobandero, con sus sobijos, rezos y emplastos, devuelve a su lugar las venas torcidas, los huesos luxados y otras descomposturas; el rezandero ayuda con sus rezos a las almas a abandonar el cuerpo cuando están penando, pero también puede influenciar sobre el espíritu de los vivos para tramarlos” (p. 222). 
en términos de la autonomía, la organización y la participación; el derecho a una visión propia del futuro; y la identidad con la lucha del pueblo negro en el mundo (PGN, 2008).

\section{La política de titulación colectiva y la formación de los Consejos Comunitarios}

En orden a comprender el proceso que llevó a la formación de los Consejos Comunitarios será preciso ahora centrar la atención en el marco normativo, pues los diferentes acercamientos que se han presentado hasta ahora carecen de un referente jurídico claro que permita dilucidar los avances y retrocesos del proceso. Así las cosas, el siguiente apartado tendrá en cuenta dos aspectos: la legislación que soporta la conformación de los consejos y las publicaciones que han discurrido sobre el tema de la titulación colectiva y la formación de estos. No obstante, es importante aclarar que estos dos aspectos no serán presentados de manera separada sino que se trabajarán de manera conjunta.

Dicho esto, se debe comenzar por hacer referencia al artículo transitorio 55, que en palabras de Carlos Agudelo (2005) representa "una conquista parcial; que si bien es cierto favorecía a las poblaciones del Pacífico rural, también excluía a las mayorías negras ubicadas en los espacios urbanos y sometidas mayoritariamente a situaciones de segregación y exclusión social" (p. 188). Sin embargo, esta "exclusión positiva" del artículo 55 no es producto del interés hegemónico de las organizaciones del Pacífico, sino mas bien, el resultado y la decantación de la ANC, pues "una primera versión de este artículo que planteaba el derecho a "territorios tradicionalmente ocupados por 'comunidades negras' pero sin hacer alusión específica al Pacífico, fue rechazado" (p. 187), y no es para menos pues una ley que le otorgara derechos territoriales a las comunidades negras en las tierras ancestralmente ocupadas hubiera representado un desbordamiento de reivindicaciones. Es así como se produce entonces la referencia explícita a la cuenca del Pacífico, que además de delimitar el espacio permite otorgarles a las comunidades de la región un carácter étnico similar al de los pueblos indígenas:

Dentro de los dos años siguientes a la entrada en vigencia de la presente Constitución, el Congreso expedirá, previo estudio por parte de una comisión especial que el Gobierno creará para tal efecto, una ley que les reconozca 
a las comunidades negras que han venido ocupando tierras baldías en las zonas rurales ribereñas de los ríos de la Cuenca del Pacífico, de acuerdo con sus prácticas tradicionales de producción, el derecho a la propiedad colectiva sobre las áreas que habrá de demarcar la misma ley (Constitución Política de Colombia de 1991, art. 55).

En este sentido, el Art. 55 no otorga derechos étnicos y territoriales a las comunidades negras, sino que abre el camino para que en los siguientes dos años se legisle al respecto. Pero a pesar de que no hay un reconocimiento legal, como el de los indígenas, si hay un notable avance en materia de inclusión y de reconocimiento de las prácticas tradicionales y de la posesión ancestral de la tierra. Quizás en razón al salto que se da de una nación homogénea a una nación pluriétnica y multicultural. A pesar de que el artículo es claro, queda por preguntarse lo que hubiera sucedido en caso de que la comisión delegada para formular la ley no hubiera logrado un acuerdo. Pues bien, como lo agrega el parágrafo 2 del mismo artículo "si al vencimiento del término señalado en este artículo el Congreso no hubiere expedido la ley a la que él se refiere, el Gobierno procederá a hacerlo dentro de los seis meses siguientes, mediante norma con fuerza de ley" (Constitución Política de Colombia, art. 55).

Con este escenario por delante la comunidad negra se moviliza como nunca antes, logrando al cabo de dos años la sanción de la Ley 70 de 1993, que siguiendo el trabajo de Carlos Agudelo (2005), transita entre logros y ambigüedades debido a que además de reconocer los derechos étnicos y territoriales de los pueblos del Pacífico introduce un concepto de comunidad negra que acaba por incluir a las poblaciones afrocolombianas de todo el territorio nacional. Pero aunque se introducen conceptos como "comunidad negra", "ocupación colectiva" y "prácticas tradicionales de producción”, la ley no reglamenta el tipo de relación que los consejos comunitarios deben asumir respecto a los poderes municipales, como las alcaldías o los consejos, llevando así a que la autoridad de estos choque con las autoridades municipales.

En el mismo horizonte se ubican las prácticas tradicionales de producción y las titulaciones colectivas de las tierras. En cuanto a lo primero se afirma que aún cuando hay comunidades que desarrollan prácticas productivas sostenibles, en su gran mayoría los pueblos del Pacífico viven una crisis 
ambiental, producto de la explotación y extracción de los recursos a manos de los agentes del capital. En cuanto a lo segundo, se muestra cómo la ley desconoce, o al menos no le otorga la debida importancia a la propiedad privada de la región, lo cual deja en evidencia una generalización respecto a las formas de acceso a la tierra que a la postre provocará conflictos intraétnicos (Agudelo, 2005).

Sin embargo, a pesar de las ambigüedades y vacíos que tiene la ley, Agudelo (2005) afirma que es un referente inequívoco de las reivindicaciones futuras del pueblo negro en Colombia. Pero al decir esto no se puede desconocer que la titulación colectiva por sí misma es un logro sin precedentes. No se debe olvidar que en el contexto de los años noventa y en las circunstancias de presión y arrinconamiento en la que se encontraban las comunidades respecto al capital y el narcotráfico era perentorio garantizar el reconocimiento de la propiedad. En estos términos, la Ley idea como estrategia administrativa la organización de las comunidades en consejos comunitarios

Son funciones de los Consejos Comunitarios: delimitar y asignar áreas al interior de las tierras adjudicadas; velar por la conservación y protección de los derechos de la propiedad colectiva, la preservación de la identidad cultural, el aprovechamiento y la conservación de los recursos naturales; escoger al representante legal de la respectiva comunidad en cuanto persona jurídica, y hacer de amigables componedores en los conflictos internos factibles de conciliación (Ley 70 de 1993, Art. 5).

Con base en esta figura aparecerán entonces trabajos como el de Ulrich Oslender (2008) o el de Odile Hoffmann (2002), en los que se habla de las diferentes vías para la conformación de los consejos comunitarios. Dejando en evidencia que más allá de la movilización del movimiento negro, producto del artículo 55, la conformación de los consejos ha sido resultato de la cooptación de diferentes actores, que para el primero se reducen al capital y a las instituciones gubernamentales; mientras que la segunda agrega también la vía de los campesinos ${ }^{13}$.

13 Según Hoffmann (2002) en Nariño hay una tercera vía para la creación de los Consejos Comunitarios que consiste en la cooptación de las comunidades de base a través del Palenque. Aunque es una forma reconocida en la conformación de estas organizaciones, se centrará la atención en las otras dos vías, debido a que ésta parece estar más en conformidad con la letra de la ley al ser promovida y organizada por las mismas comunidades. Mientras que las otras dos dejan en evidencia un problema de 
Los consejos comunitarios del medio Atrato en la vía del posdesarrollo Hacia un modelo deliberatorio de organización de las comunidades negras

Oslender (2008) sostiene que en el departamento de Nariño los procesos de representación comunitaria han sido mediados por los intereses del capital, en la medida que consejos como UNICOSTA - del que ya se habló antes- dejan ver que el proceso para constituir este tipo de organizaciones no siempre debe responder a las lógicas culturales y étnicas inherentes a la cuenca, sino que pueden translucirse en maniobras disfrazadas de empresas, que como ALENPAC manifiestan la aparente sostenibilidad de la explotación de palmitos. En esta medida, aún cuando es en sí problemático el hecho de que no sean las comunidades mismas las que se organicen, lo más complicado de este tipo de consejos es su sostenibilidad en el tiempo

Si se forma un consejo comunitario alrededor de la lógica extractiva de la explotación del Naidí y esta industria fracasa (como en el caso de ALENPAG), toda la lógica espacial configurada en las tierras donde crece la palma se desbarata. Se podría inclusive decir que el consejo comunitario UNICOSTA pierde su razón de ser, pues la ruptura con la lógica del río, para favorecer demandas del capital externo, ha iniciado una segregación espacial de la cuenca del río. Bien es posible que con la caída de la economía extractiva del Naidí también se debiliten las estructuras organizativas locales, pues se le ha quitado su base y su lógica de funcionamiento (Oslender, 2008, p. 228).

En cuanto a la mediación de la representación gubernamental se hace referencia al Instituto Colombiano de la Reforma Agraria-INCORA-, que en su función de titulación de las tierras de las comunidades negras termina extralimitándose y vanagloriando procesos como el de UNICOSTA o asumiendo una actitud condescendiente hacia los procesos locales de organización. Ciertamente la cooptación en esta vía no se produce por un interés extractivo como en el caso del capital, sino como resultado del cumplimiento de los requerimientos legales. En estas condiciones el agente gubernamental en orden a cumplir su función busca propiciar espacios de organización ajenos a la lógica de los ríos que de manera trágica llevan a pensar que "hay un peligro real de que se conviertan en espacios burocratizados, más obligados con los requerimientos legales de mantener elecciones regulares que con los esfuerzos reales por generar conciencia entre los pobladores locales sobre sus derechos" (Oslender, 2008, p. 23)14.

organización y cooperativismo que no debería existir en el marco de una "titulación colectiva" y un reconocimiento de derechos étnicos.

14 En el capítulo tercero de esta investigación se retomará este planteamiento de Oslender, según el cual, la lógica de los Consejos es extraña a la lógica de los ríos en 
Así las cosas, el asunto de los consejos comunitarios se vuelca sobre las comunidades de base, pues contrario al espíritu de la ley 70 de 1993 y la movilización del artículo 55 da la impresión de que este tipo de organizaciones están en función del poder y el capital. Es en este contexto que se desarrolla el trabajo de Sandra Patricia Martínez (2010), que más allá del fundamento legal de la política de titulación colectiva o de los resultados cuantitativos de su ejecución, le interesa atender a las interpretaciones locales de la ley. En su documento expone diferentes situaciones de conflicto que van desde los títulos colectivos y los títulos privados hasta los contratos de arrendamiento y de venta en la región. Veamos un caso para entender en profundidad lo que quiere mostrar la autora

[...] los propietarios de las retroexcavadoras, o retreros, como son denominados localmente, bajo el argumento de que estos territorios aún no han sido titulados, se han instalado en la región estableciendo contratos leoninos con los propietarios de los terrenos de mina (frentes mineros o de cateo). Ignorantes del carácter inalienable, inembargable e imprescriptible que ostentan estas tierras, muchas de las familias dueñas de los frentes mineros "venden" estos terrenos a los retreros, quienes respaldan su ingreso a la zona con documentos de compra-venta apócrifos (p. 30).

Esta situación deja en evidencia un problema enorme en términos de la interpretación de la ley y la pedagogía de la alteridad de la que habla Restrepo (2002), pues se pone en evidencia la dificultad de transmitir los contenidos de la legislación a las comunidades. Más aún, resulta problemático el hecho de que los consejos pierdan la facultad de defender el territorio, sobre todo en razón a que los habitantes del lugar legitiman la explotación a través de contratos subrepticios. Pero en el fondo lo que explica esta situación es que los pobladores locales al sembrar sus expectativas de una mejor calidad de vida en la Ley 70 de 1993 y ver que los consejos no han resuelto sus problemas, se ven avocados a resolver su situación económica de manera individual, ocasionando perjuicios al territorio y al proceso organizativo. Lo más grave del asunto es que las responsabilidades que el Estado debería asumir y que en últimas no son garantizadas se le atribuyen a los consejos,

la que han vivido los habitantes de la Cuenca del Pacífico. Vale la pena agregar que el interés en este planteamiento tiene que ver con el hecho de que la organización de los Consejos refiere a la lógica occidental de la democracia liberal, que en todo sentido resulta extraña a las lógicas no representativas de estas comunidades. 
llevando a que los pobladores se desmotiven y dejen de participar en el proceso (Martínez, 2010).

Éste no es el único problema como lo anota la autora, la férrea oposición de los partidos oficiales y de los dirigentes políticos así como la carencia de recursos de los dignatarios para el ejercicio de sus funciones son también barreras que se le presentan al proceso organizativo. Sin embargo, aún cuando parece difícil solventar todas estas adversidades vale la pena hacer dos salvedades; primero que los trabajos que se han presentado hasta ahora centran su atención en el alto o en el bajo Atrato y no en el medio Atrato, donde se concentra el proceso sino más exitoso, al menos más duradero y estable -se hace referencia a la ACIA-. Segundo, aunque este trabajo centra su atención en el medio Atrato resulta importante tener en cuenta los problemas que se han presentado en otros lugares del Pacífico, pues, tal vez allí aunque no se ha documentado el tema también hay casos similares.

Finalmente, para cerrar este apartado se puede anotar que el problema de la Ley 70 de 1993, más allá de sus vacíos y ambigüedades consiste en que el gobierno no la reglamentó en su totalidad. Eso quiere decir que solo reglamentó el capítulo tercero, sobre la titulación colectiva-Decreto 1745 de $1995^{15}$ - dejando de lado otros capítulos, igual o más importantes, como por ejemplo el séptimo sobre la "planeación y fomento del desarrollo económico y social". Quizás si se hubiera legislado en torno a este capítulo y se hubiera resuelto el problema socioeconómico de las comunidades sería más fácil para éstas organizarse en los consejos. No se debe olvidar que la organización de los consejos aunque otorga personería jurídica tiene un vacío con respecto a los recursos, pues las comunidades no reciben presupuesto al no ser entes territoriales, ni tampoco tienen la facultad de hipotecar sus tierras con el fin de solicitar préstamos. En suma, la literatura que discurre sobre la formación de los consejos comunitarios y la titulación colectiva en su mayoría atiende al problema de su creación, conformación y sostenibilidad, así como a la cooptación del capital y el Estado.

15 El Decreto 1745 de 1995, reglamenta el capítulo III de la Ley 70 de 1993, adoptando el procedimiento para el reconocimiento de la propiedad colectiva de las tierras de las Comunidades Negras. Estableciendo, entre otras cosas, las funciones de los órganos rectores más importantes: la asamblea, la junta y el representante legal. 


\section{Los movimientos sociales y los estudios de género}

Aun cuando los consejos comunitarios representan una organización colectiva, producto de la movilización social de las comunidades negras en los años ochenta y noventa, no es muy abundante la literatura que habla de este tipo de organizaciones a partir de la perspectiva de los movimientos sociales desde el punto de vista de los estudios de género. Pero decir esto podría llevar a malos entendidos, pues el trabajo de Arturo Escobar, Libia Grueso y Carlos Rosero entre otros académicos y activistas, se concentra precisamente en reconocer la comunidad negra del Pacífico como un movimiento social con pretensiones reivindicativas. El mismo Escobar ahondará en corrientes como la subalternidad y planteará "estrategias subalternas de localización", o incluso "políticas de lugar" (Escobar, 2005a). No obstante, lo que sí es difícil de rebatir, es que no hay muchos trabajos en los que se examine el papel de la mujer dentro del proceso organizativo de las comunidades negras que se gesta a partir de la Ley 70 de 1993.

Entre los trabajos que se pueden encontrar está un artículo de Leonardo Montenegro (2002) en el que el autor busca "implementar estudios sobre cómo las relaciones de género y las actividades que comportan constituyen y modifican el entorno" (p. 90). A su juicio, uno de los elementos más relevantes en términos de la justificación del enfoque para acercarse a los consejos comunitarios tiene que ver con el hecho de que los procesos de titulación colectiva están enmarcados en una participación ficticia, en donde la mujer está afuera de la toma de decisiones. En estos términos, el autor define el género como:

[...] una referencia analítica a un proceso de construcción social de lo que compromete ser un hombre o una mujer. Es importante resaltar que es un proceso social y no un producto biológico; hace referencia a todas las diferencias entre hombres y mujeres que han sido construidas socialmente. Por ello, la diferencia con respecto al sexo es muy clara, en cuanto que éste es biológico (Montenegro, 2002, p. 89).

Además del género el autor toma en cuenta los conceptos de relaciones de género y roles de género, con los que busca aludir a los patrones específicos que tiene la mujer respecto a su entorno; es decir, el tipo de roles y de relaciones que se instituyen a partir de su condicionamiento. Así es que, siguiendo la argumentación que presenta, se afirma que el enfoque de los roles lleva 
a distinguir una división sexual del trabajo entre hombres y mujeres, según la cual la predisposición biológica conduce a la primera a desempeñar las tareas reproductivas, quedándole poco tiempo para participar de los asuntos públicos.

Así las cosas, Montenegro (2002) infiere que la mujer ha sido invisibilizada en el Pacífico como interlocutora válida frente al Estado, al no ser incluida en actividades de importancia dentro del proceso organizativo. Hecho que para él representa una negación del trabajo de la mujer y una violación de sus derechos civiles. Es de anotar que sus conclusiones son producto de charlas con hombres y mujeres de la región y con investigadores del tema. A pesar de que el trabajo que presenta es del año 2002, es importante señalar que la inclusión de la mujer dentro del proceso organizativo cada vez ha sido más significativa, hasta el punto que en la actualidad las dos "altas consultivas de las comunidades negras" para el departamento del Chocó, son mujeres.

Otro trabajo relevante es un artículo de Libia Grueso y Leyla Arroyo (2007), en el que se plantea una tesis controversial respecto al trabajo de Montenegro. Para las autoras, en el marco de la movilización y reivindicación que el PGN ha venido adelantando, las mujeres "han creado un espacio de organización como mujeres y lo han logrado al hacer cada vez más visible su papel en la defensa del territorio, el lugar y la identidad" (p. 114). Pero lo más controversial del asunto no es esto, sino que lo hacen a través de prácticas cotidianas que van desde el cultivo de alimentos hasta la organización. Algo que para Montenegro denota más bien una división sexual del trabajo en tanto que delega a las mujeres labores domésticas en razón de su género.

Sin embargo, es preciso reconocer que las diferencias entre los autores no tienen que ver con una lectura errada de parte de alguno, sino que se refieren a interpretaciones divergentes sobre el mismo fenómeno. Esto se demuestra cuando Grueso y Arroyo (2007) sin notarlo aluden a la división sexual del trabajo señalando la natural diferencia entre las actividades que desempeñan los hombres y las actividades que desarrollan las mujeres

Por lo general, las mujeres están a cargo de los aspectos productivos que permiten un regreso permanente al espacio doméstico, con lo que se asegura la socialización y la integración de la familia, incluido el cuidado de niñas, 
niños y personas ancianas, mientras que los hombres asumen las tareas que requieren mayor fuerza física y tiempo lejos del entorno familiar (p. 115).

Quizás la diferencia entre los autores radica en que Montenegro desde una perspectiva feminista, intenta acercarse al rol de la mujer dentro del movimiento negro del Pacífico; mientras que Grueso y Arroyo se acercan al papel de la mujer en el proceso organizativo desde un punto de vista vivencial y reivindicativo. No hay que dejar de lado el rol participativo que ellas mismas desempeñan como activistas dentro del PGN.

En este orden de ideas, Arturo Escobar (2010) consciente de la invisibilización de la que habla Montenegro y reconociendo la segregación de la mujer a labores secundarias dentro del movimiento negro, se pregunta la razón por la cual, a pesar de que las mujeres se encuentran dentro de los más prominentes líderes del PGN -por ejemplo--, hasta ahora este movimiento no ha llevado una articulación explícita entre la lucha étnica que lo moviliza y la perspectiva de género. Una pregunta que sin lugar a dudas espera resolver la incógnita ya planteada en los textos anteriores, pues no es clara la razón por la cual Grueso y Arroyo reivindican el papel de la mujer dentro del movimiento sobre la base de prácticas en las que claramente se deja en evidencia la división sexual del trabajo.

En estos términos, Escobar (2010) señala que las razones por las que la dimensión de género no se ha articulado a la lucha dentro del movimiento a pesar de que son complejas se pueden evidenciar en tres niveles. Al respecto el autor colombiano sigue de cerca el planteamiento de Juliana Flórez, quien afirma que en primer lugar se debe hacer claridad sobre el tipo de lucha que emprenden los afrocolombianos y su correspondencia con las reivindicaciones de género; en segundo lugar, los posicionamientos y estrategias de las activistas mujeres que en sí mismas constituyen desafíos a las relaciones de género existentes; y en tercer lugar, las prácticas diarias que perturban los patrones culturales de género.

$\mathrm{Al}$ respecto arguye Escobar, siguiendo el punto de vista de activistas del movimiento, que las discusiones sobre las relaciones de género deben partir del reconocimiento de las múltiples formas de subordinación de las personas negras. De manera que las razones por las que tal vez no hubo una discusión profunda sobre el rol de la mujer en los años noventa tienen que ver con una cuestión de prioridades, pues en su momento lo más relevante era el tema 
étnico y territorial. En cuanto al rol desempeñado por las mujeres activistas, basta con hacer referencia al discurso de autoras como Grueso y Arroyo, que sin dar tregua a sus reivindicaciones étnicas legitiman la distribución del trabajo. Es así como se afirma en alusión a las prácticas diarias de las mujeres, que son ellas mismas las que las aceptan y defienden. Por tanto, como se deduce de un proyecto político citado por Escobar, si las prácticas machistas son acolitadas por las mujeres, la transformación de estas prácticas debe comenzar por ellas mismas (Escobar, 2010).

En conclusión, para cerrar este apartado basta con agregar que los trabajos sobre el papel de la mujer, desde los estudios de género, dentro del movimiento negro y específicamente en los consejos comunitarios es aún pobre. Esto quiere decir que es un campo que bien podría ser explotado por las feministas, pero al mismo tiempo es un reto para activistas y académicos, pues lo difícil de la reivindicación de los derechos de las mujeres dentro de estas comunidades es que las mujeres no son conscientes de su dominación y de su papel diferencial dentro de la organización social. En estos términos, de cara a la investigación que aquí se adelanta, es preciso afirmar que la mujer debe ser reconocida como "otro" y en consecuencia se le debe otorgar un papel preponderante dentro de los consejos. Papel que, sin lugar a dudas, debe darle una mayor participación en la toma de decisiones públicas. Algo que contrasta de facto con la distribución sexual del trabajo presente en los pueblos del Pacífico. 

Gapítulo 2.

\section{EL POSDESARROLLO Y LA DEMOGRAGIA DELIBERATIVA: MARGOS EXPLICATIVOS PARA EL ANÁLISIS DE LOS GONSEJOS GOMUNITARIOS}

$\mathrm{E}$ $n$ un intento por construir un puente de comunicación con las comunidades afrocolombianas del Pacífico y específicamente con las comunidades del medio Atrato, el siguiente capítulo planteará en primer momento una conceptualización del posdesarrollo; para luego en un segundo momento atender a la concepción deliberativa de la democracia. El móvil que se persigue tiene que ver con el propósito de establecer marcos normativos desde los que sea posible llevar a interpretaciones plausibles sobre el fenómeno de los consejos comunitarios. Es decir, que por un lado se establecerán las bases para pensar si estos consejos y las comunidades que les subyacen pueden ser entendidas en una lógica no occidental desde el punto de vista de sus prácticas culturales y su organización; y por otro lado se afianzarán los criterios para pensar en una articulación entre la democracia deliberativa y el posdesarrollo. Es de anotar que este capítulo prescindirá de cualquier referencia empírica en tanto que su cometido es meramente teórico y parte de la necesidad de una fundamentación conceptual antes de emprender un análisis en el que se comprometan interpretaciones sobre los hechos. 


\section{E1 posdesarrollo}

El primer marco teórico de esta investigación toma como punto de partida la preocupación por entender las lógicas locales desde una perspectiva no occidental. Es preciso reconocer inicialmente que el modo como se conoce, se piensa y se enjuicia la realidad toma como fundamento los prejuicios socioculturales. De manera que atender a una realidad como la que viven las comunidades del Pacifico desde una visión occidental, capitalista, desarrollista y moderna, en última instancia presupone imponer lógicas ajenas a la realidad de estos pueblos. En esta medida reconociendo la problemática construcción discursiva de la realidad en términos de vocablos como "subdesarrollo" o "bárbaro", y teniendo presente que esta construcción transforma las prácticas y las dinámicas sociales, se puede afirmar que el posdesarrollo emergió como un insumo teórico de destacada trascendencia, en orden a deconstruir los prejuicios occidentales de la visión moderna, permitiendo además dilucidar propuestas alternativas.

En este sentido, reconociendo la importancia de este marco conceptual en el camino a comprender las lógicas no occidentales de los pueblos del Pacífico y específicamente del Medio Atrato, será preciso plantear en primer lugar las críticas que se le plantean a las teorías del desarrollo clásicas, para luego en un segundo momento atender a los insumos teóricos del posdesarrollo. No sobra agregar que la conceptualización de este apartado llevará a pensar si es posible comprender con lógicas no occidentales prácticas organizativas como las que se vienen gestando a través de los consejos comunitarios.

\section{Gríticas al desarrollo.}

Orlando Fals Borda citado por Escobar (1996), plantea la necesidad de confrontar el desarrollo arguyendo que el mundo dependiente no puede aceptar como la panacea el punto IV de Harry Truman ${ }^{1}$. A su juicio, es

Escobar (1996), más adelante, en el mismo texto cita el discurso de Truman: "Mas de la mitad de la población del mundo en condiciones cercanas a la miseria. Su alimentación es inadecuada, es víctima de la enfermedad. Su vida económica es primitiva y está estancada. Su pobreza constituye un obstáculo y una amenaza tanto para ellos como para las áreas más prosperas [...] creo que deberíamos poner a disposición de los amantes de la paz los beneficios de nuestro acervo de conocimiento técnico para ayudarlos a lograr sus aspiraciones de una vida mejor [...] lo que tenemos en mente es un programa de desarrollo basado en los conceptos de trato justo y democrático (p. 19). 
urgente este rechazo en la medida que allí se está jugando "la autonomía, la personalidad y la cultura" de nuestros pueblos. Igualmente, resulta elocuente e inspiradora la presentación que se hace de la empresa emprendida por Escobar, pues según Borda en el libro se busca "trascender las diferencias con el Primer Mundo a través de la posibilidad de defender nuestro humanismo dentro del horizonte posmoderno" (p. 11).

El mismo Escobar presenta su texto diciendo que en él se narra la forma como el sueño de la transformación total de las culturas y formaciones sociales de tres continentes; de acuerdo con los dictados del Primer Mundo se convirtió en una pesadilla, porque "en vez de la tan anhelada transformación parece que el desarrollo solo hubiera logrado multiplicar al infinito los problemas socioeconómicos de Asia, África y América Latina” (Escobar, 1996, p. 13), agregando, en relación con el enfoque posestructuralista que asumía el libro, que éste "parte del reconocimiento de la importancia de las dinámicas de discurso y poder en la creación de la realidad social y en todo estudio de la cultura" (p. 14). En otras palabras, se buscaba examinar el régimen de representación del desarrollo como moldeador de la realidad y la acción social de los países que desde este discurso se concebían como "subdesarrollados".

Dicho esto, el libro comienza atendiendo a la génesis del discurso desarrollista que como habíamos notado antes era posible rastrear en la Doctrina Truman. Doctrina que a juicio del autor:

[...] inicio una nueva era en la comprensión y el manejo de los asuntos mundiales, en particular de aquellos que se referían a los países económicamente menos avanzados. El propósito era bastante ambicioso: crear las condiciones necesarias para reproducir en todo el mundo los rasgos característicos de las sociedades avanzadas de la época: altos niveles de industrialización y urbanización, tecnificación de la agricultura, rápido crecimiento de la producción material y los niveles de vida, y adopción generalizada de la educación y los valores culturales modernos. En concepto de Truman, el capital, la ciencia y la tecnología eran los principales componentes que harían posible tal revolución masiva. Solo así el sueño americano de paz y abundancia podría extenderse a todos los pueblos del planeta" (Escobar, 1996, p. 14)

El desarrollo del que hablaba Truman es presentado por un documento de Naciones Unidas, citado por Escobar (1996), como una vía a través de la cual "las filosofías ancestrales deben ser erradicadas; las viejas instituciones 
sociales tienen que desintegrarse; los lazos de casta, credo y raza deben romperse" (p. 20). En otras palabras se busca imponer un modelo de sociedad, un modelo de desarrollo y un modelo de vida, sobre la base de los constructos y parámetros de las sociedades avanzadas. Lo trágico es que el medio para hacerlo es erradicando las culturas locales, bajo el presupuesto de la deslegitimación de lo propio y la exaltación de lo foráneo.

Pero contrario a lo que pensaban los técnicos y los expertos del desarrollo, Escobar (1996) demuestra que el sueño de Truman terminó por convertirse en una pesadilla. "En vez del reino de abundancia prometido por teóricos y políticos de los años cincuenta, el discurso y la estrategia del desarrollo produjeron lo contrario: miseria y subdesarrollo masivos, explotación y opresión sin nombre" (p. 21). La panacea de un mundo mejor bajo los dictados de la razón terminó siendo un fiasco. El intento por emular las condiciones de los países avanzados acabó por agravar las condiciones socioeconómicas de los países más pobres. Lo más grave de todo fue la crisis cultural que provocaron estos modelos al imponer lógicas foráneas, en desmedro de las prácticas vernáculas y las tradiciones ancestrales.

Todo esto fue producto de las certezas que se incubaron en los años setenta, trayendo como resultado una deconstrucción del imaginario colectivo, según el cual, la realidad

[...] había sido colonizada por el discurso del desarrollo, y quienes estaban insatisfechos con este estado de cosas tenían que luchar dentro del mismo espacio discursivo por porciones de libertad, con la esperanza de que en el camino pudiera construirse una realidad diferente (Escobar, 1996, p. 22).

Es así que en conformidad con la concepción posestructuralista que asume Escobar, las dinámicas del discurso y el poder producen unos modos permisibles de ser y de pensar mientras que descalifican e imposibilitan otros.

Ver el desarrollo como un discurso implica entender las razones que llevaron a los países pobres a entenderse como subdesarrollados, y en sintonía asumir la tarea de "des-subdesarrollarse". Pero este discurso no es nuevo y la negación de la alteridad ha tenido varios momentos. Escobar (1996) muestra como para Iván Illich "la percepción del extranjero como alguien que necesita ayuda ha tomado sucesivamente las formas del bárbaro, el pagano, el infiel, el salvador, el nativo y el subdesarrollado" (p 26). Esto 
implica que el discurso sobre el desarrollo no es más que una de las formas de dominación que ha asumido el mundo occidental.

Ahora bien, sin entrar a examinar las diferentes estrategias del desarrollo -los campesinos, las mujeres y el ambiente- es preciso entender el modo cómo un discurso terminó por convertirse en un componente integral del ejercicio del poder. Al respecto, Escobar (1988) comenta que se llevaron a cabo dos mecanismos:

1) La profesionalización del desarrollo. El concepto de profesionalización se refiere a un conjunto de técnicas y prácticas disciplinares a través de las cuales la generación, difusión y validación del conocimiento es organizada, manejada y controlada; en otras palabras, es el proceso por el cual la verdad conveniente es creada y mantenida. En el curso del desarrollo, éste fue alcanzado por la aplicación de las disciplinas existentes a los problemas del tercer mundo, o por la creación de nuevas subdisciplinas [...] 2) La institucionalización del desarrollo. Este mecanismo se refiere al establecimiento de un campo institucional en el cual, y desde el cual, los discursos y las técnicas son producidas, registrados, estabilizados, modificados y puestos en operación. El trabajo en red de desarrollo en las instituciones responsables de este efecto, se extiende desde las organizaciones institucionales (como las Naciones Unidas y sus agencias "técnicas", instituciones bilaterales: ejemplo Estados Unidos: agencia para el Desarrollo Internacional") y agencias voluntarias (por ejemplo: CARE), agencias nacionales, regionales y locales en el tercer mundo (pp. 430-431).

Estos dos mecanismos trasformaron profusamente la realidad latinoamericana, pues de un lado con el viro epistemológico de las universidades norteamericanas y con la emergencia de "estudios sobre el desarrollo", se impuso una verdad universal sobre el camino que debían seguir los países del tercer mundo. Una verdad que acabaría por convertirse en receta, teniendo en cuenta que las elites latinoamericanas eran educadas en los Estados Unidos; y de otro lado, con la operacionalización del desarrollo a través de la implementación de programas por parte de organismos multilaterales, estatales y voluntarios.

Dicho esto se puede concluir diciendo que la profesionalización e institucionalización del desarrollo no logró los cometidos que se proponía, pues las diferencias entre los "países desarrollados" y los llamados "países en desarrollo" crecieron aún más. Escobar no es el único que plantea críticas al desarrollo como lo sostiene Margaret Everett; también autores como Geoff 
Wood o Leigh Pigg han cuestionado la imposición de modelos foráneos. Esta última por ejemplo siguiendo a Everett (1997), cuestiona el modo como la modernización termina implantándose en las culturas locales.

\section{Los postulados del posdesarrollo.}

Quizás uno de los aspectos más cuestionables de las teorías del desarrollo es que intentan imponer lógicas occidentales a fenómenos no occidentales. De forma tal que se promueven políticas sobre la base de necesidades construidas foráneamente, transformando la cultura y despreciando los conocimientos y las culturas vernáculas. En este sentido, el siguiente apartado se propone establecer los insumos teóricos del posdesarrollo, buscando con ello establecer los parámetros normativos desde los que se espera acercarse a organizaciones sociales como los consejos comunitarios del medio Atrato. De este modo, a continuación se presentará en primer lugar una génesis del concepto de posdesarrollo; en segundo lugar, una descripción de los diferentes acercamientos teóricos que se han hecho al posdesarrollo; y finalmente, en tercer lugar se plantearán las respuestas a críticas que desde diferentes vertientes se le han hecho a este marco conceptual.

\section{La génesis del concepto.}

Wolfgang Sachs en la introducción al volumen colectivo del Development Dictionary, establece a manera de sentencia que: "Los últimos cuarenta años pueden ser denominados la era del desarrollo. Esta época está llegando a su fin. Ha llegado el momento de escribir su obituario" (Sachs, 1992, p. 1). A juicio del autor la idea del desarrollo orientó el camino de las naciones emergentes después del fin de la Segunda Guerra Mundial, sirviendo de faro a las acciones emprendidas para paliar la pobreza y, en general, todos los problemas que aquejaban a las naciones de América Latina, Asia y África. Es así que desde entonces, las relaciones entre el norte y el sur han estado moldeadas por el desarrollo de tal manera que la generosidad, el soborno y la opresión que han caracterizado las políticas hacia el sur, siempre se han amparado en esta idea con halos de altruismo (Sachs, 1992).

Sin embargo, como lo muestra Sachs (1992):

Hoy el faro muestra grietas y ha comenzado a desmoronarse. La idea de desarrollo se levanta como una ruina en el paisaje intelectual. El engaño y la 
Los consejos comunitarios del medio Atrato en la vía del posdesarrollo Hacia un modelo deliberatorio de organización de las comunidades negras

desilusión, los fracasos y los crímenes han sido compañeros permanentes del desarrollo y cuentan una misma historia: no funcionó (p. 1).

En otras palabras, el discurso del desarrollo resultó inútil en su propósito de resolver los problemas de los países del sur. Pero, a pesar de que éste discurso resultó caduco, sigue dominando la escena como un hito que moldea la realidad y que llega hasta el punto de transformar las mismas necesidades, valores y lenguajes de los movimientos de base (Sachs, 1992).

No obstante, con el tiempo las dudas han ido creciendo y cada vez son más los que se sienten incómodos con el discurso del desarrollo. Más aún si se tiene en cuenta que la era del desarrollo está llegando a su fin; debido a que sus cuatro premisas fundamentales se han hechos obsoletas por la historia (Sachs, 1992). La primera de estas premisas se refiere a la industrialización, dado que sí todos los países hubieran seguido el modelo de consumo del primer mundo "se habrían necesitado como cinco o seis planetas para servir como minas y muladares"; la segunda hace referencia al hecho de que el desarrollo se erigió como un arma de competencia de los Estados Unidos para confrontar el comunismo en los países que salían de la colonización, así que con el fin de la guerra fría el discurso desarrollista se halla condenado a "perder vapor ideológico y a quedarse sin combustible político"; la tercera deja en evidencia que el desarrollo cambió la imagen del mundo pero de forma paradójica, pues mientras que "en 1960 los países del norte eran veinte veces más ricos que los del sur; en 1980 lo eran cuarenta y seis veces"; y la cuarta de estas premisas, no hace más que ratificar que el proyecto del desarrollo no era otro que el de la "Occidentalización del mundo"; la perdida de la diversidad y la homogenización de los deseos y sueños². En estos términos como lo sentencia Sachs, lo que se debe temer no es el fracaso del desarrollo; sino su cuestionable éxito de manera que cualquier esfuerzo

\footnotetext{
Para Sachs (1992) el resultado del desarrollo ha sido la pérdida de la diversidad, en sus palabras, "La simplificación planetaria de la arquitectura, del vestido y de los objetos de la vida diaria saltan a la vista; el eclipsamiento paralelo de lenguajes, costumbres y gestos diversificados es ya menos visible; y la homogeneización de deseos y sueños ocurre profundamente en el subconsciente de las sociedades. El mercado, el Estado y la ciencia han sido las grandes potencias universalizantes; publicistas, expertos y educadores han expandido su reino implacablemente. Naturalmente, como en los tiempos de Moctezuma, los conquistadores frecuentemente han sido cálidamente recibidos, solo para luego hacer sentir su dominación. El espacio mental en que la gente suena y actúa está ocupado hoy en gran medida por la imaginería occidental” (p. 4).
} 
imaginativo por concebir una era de posdesarrollo tendrá que superar las limitaciones del desarrollo (Sachs, 1992) ${ }^{3}$.

De este modo teniendo en cuenta lo anterior, Arturo Escobar (2006) muestra como el Diccionario del Desarrollo editado por Wolfgang Sachs (1992) deja sentenciado el fin de la era del desarrollo. Esta sentencia deja abierta la posibilidad de hablar de una "era del posdesarrollo" (Escobar, 1995; Rahnema, 1997). Lo que deja en evidencia que el texto de Sachs marca el fin y el comienzo de una nueva era; el fin del desarrollo y el comienzo del posdesarrollo.

\section{Acercamientos teóricos al posdesarrollo.}

Arturo Escobar (2005b) muestra que la noción de posdesarrollo proviene de la crítica postestructuralista y por ende su interés no radica en proponer otra versión del desarrollo sino en cuestionar los modos en que Asia, África y América Latina llegaron a ser considerados como "subdesarrollados". En este sentido:

La pregunta que se hicieron los postestructuralistas no fue ¿cómo podemos mejorar el proceso de desarrollo?, sino ¿por qué, por medio de qué procesos históricos y con qué consecuencias Asia, África y Latinoamérica fueron 'ideadas' como el 'Tercer Mundo' a través de los discursos y las prácticas del desarrollo? (p. 18)

Escobar (2005b) plantea cuatro elementos que han contribuido a responder a la pregunta: primero el discurso histórico, a través del cual se ha mostrado que el desarrollo surgió durante el periodo posterior a la segunda guerra mundial construyendo así la idea del "subdesarrollo" y del "tercer mundo"; segundo, las fuerzas reales y efectivas a través de las cuales se ha mostrado que el discurso del desarrollo hizo posible la creación de un aparato institucional capaz de transformar la realidad social, económica, cultural y política de las sociedades del tercer mundo; tercero, la profesionalización de los problemas del desarrollo, a partir de lo cual se institucionalizó el conocimiento de los expertos como una vía idónea para resolver los problemas

Es importante tener en cuenta que el mismo Wolfgang Sachs anuncia una era del posdesarrollo, solo que desde su punto de vista no atenderá a una comprensión postestructuralista, en el sentido de Arturo Escobar, sino a un momento ulterior del desarrollo que resuelva las limitaciones de este discurso. 
del subdesarrollo; y cuarto, la paradójica exclusión de los conocimientos, las voces y las preocupaciones de aquellos que debían beneficiarse del desarrollo (p. 19).

En estos términos se puede decir que el posdesarrollo no es un período histórico al que sus proponentes piensan que hemos llegado y menos aún puede ser considerado como un estadio ulterior al desarrollo, como si éste hubiera alcanzado los objetivos que se había trazado. Antes bien, la idea del posdesarrollo como anota Escobar (2005b) se refiere a:

(a) la posibilidad de crear diferentes discursos y representaciones que no se encuentren tan mediados por la construcción del desarrollo (ideologías, metáforas, lenguaje, premisas, etc.); b) por lo tanto, la necesidad de cambiar las prácticas de saber y hacer y la "economía política de la verdad" que define al régimen del desarrollo; c) por consiguiente, la necesidad de multiplicar centros y agentes de producción de conocimientos - particularmente, hacer visibles las formas de conocimiento producidas por aquéllos quienes supuestamente son los "objetos" del desarrollo para que puedan transformarse en sujetos y agentes; d) dos maneras especialmente útiles de lograrlo son: primero, enfocarse en las adaptaciones, subversiones y resistencias que localmente la gente efectúa en relación con las intervenciones del desarrollo (como con la noción de "contra-labor" que se explica más abajo); y, segundo, destacar las estrategias alternas producidas por movimientos sociales al encontrarse con proyectos de desarrollo(p. 20).

De este modo no se trata de un momento ulterior al desarrollo, sino más bien de una desconstrucción del desarrollo, pues lo que se busca es revaluar la idoneidad del conocimiento de los expertos y abrir espacio para que las comunidades y los movimientos sociales se pronuncien sobre el camino que desean seguir. Se busca acabar con la idea de que las instituciones y los profesionales ajenos a las realidades culturales de las comunidades impongan un modelo de desarrollo como si se tratara de una receta, para así abrir espacio al diálogo entre los expertos y los grupos antes marginados.

La revaloración de las culturas vernáculas debe venir acompañada de una estrategia de posicionamiento de los discursos y prácticas locales, de tal forma que las comunidades de base puedan confrontar el capital. Es así como Escobar (1996) plantea que las estrategias de organización de los movimientos sociales han comenzando a girar en torno a dos principios: 
(1) La defensa de la diferencia cultural, como fuerza transformadora y transformada, no estática, y (2) la valoración de necesidades y oportunidades económicas en términos que no sean solamente los de la ganancia y el mercado. La defensa de lo local como prerrequisito para articularse con lo global, la crítica de la propia situación, valores y prácticas de grupo como manera de clarificar y fortalecer la identidad, la oposición de desarrollo modernizante, y la formulación de visiones y propuestas concretas en el contexto de las restricciones (p. 423).

De manera que las comunidades de base que han entrado en este proceso de movilización en orden a acceder al posdesarrollo deben experimentar estrategias productivas alternativas y simultáneamente deben llevar a cabo una "resistencia semiótica" a la restructuración del capital y la visión moderna del desarrollo, lo cual implica que "la descentralización económica, la desburocratizacion del manejo ambiental, el pluralismo político, la autonomía cultural y la productividad ecológica pueden servir como criterios globales para emprender la estrategia" (Escobar, 1996, pp. 386-387). Una estrategia que a juicio de Escobar ha sido cada vez más frecuente en grupos populares de muchas partes del mundo, que desde discursos sobre el pluralismo cultural, la biodiversidad y la etnicidad le han hecho frente a los mecanismos convencionales del desarrollo, creando visiones novedosas de sí mismos y de su mundo circundante.

Para Gustavo Esteva (2009) la vía del posdesarrollo no significa otra cosa que ponerse a construir un mundo en el que quepan muchos mundos:

En vez del viejo sueño perverso de un mundo unificado e integrado bajo la dominación occidental, que Estados Unidos tomó en sus manos al final de la Segunda Guerra Mundial, se trata de abrirse hospitalariamente a un pluriverso, en que las diferencias culturales no solo sean reconocidas y aceptadas sino celebradas. Posdesarrollo, en ese contexto, significa también celebrar las innumerables definiciones del buen vivir de quienes han logrado resistir (p. 4)

Se debe pensar en un escenario en el que no primen los puntos de vista de los expertos y los técnicos del desarrollo; sino donde el discurso de los que hasta ahora han estado excluidos - por considerarse "barbaros", "atrasados", o subdesarrollados"- también sea tenido en cuenta. En esta medida, se deben incluir las diferentes concepciones sobre la vida buena, sin que el experto superponga sus necesidades sobre los deseos y requerimientos de la 
comunidad; en otras palabras, se debe escuchar al otro y atender a lo que quiere sin presuponer qué es lo que desea.

Con base en lo anterior, buscando concretar los parámetros normativos desde los que se puede entender el marco teórico trabajado en este apartado se retoma a Escobar (2008) que puntualiza los siguientes criterios:

A nivel de los imaginarios, el posdesarrollo apunta a la creación de un espacio/tiempo colectivo donde el 'desarrollo' cese de ser el principio central que organiza la vida económica y social. Esto implica los siguientes elementos: cuestionar la preeminencia del concepto de crecimiento económico y éste como meta; hacer visible la matriz cultural de donde proviene el desarrollo y su historicidad (visión dominante de la modernidad); desarticular paulatinamente en la práctica el modelo de desarrollo basado en la premisa de la modernización, la explotación de la naturaleza como ser no vivo, la exportación, y la acción individual. Por el lado afirmativo, implica a) reconocer la multiplicidad de definiciones e intereses alrededor de las formas de sustento, las relaciones sociales, y las prácticas económicas y ecológicas; b) el diseño de políticas desde cosmovisiones relacionales, en vez de la cosmovisión dualista dominante; c) establecer diálogos interculturales alrededor de las condiciones que podrían devenir en un pluriverso de configuraciones socio-naturales (multiplicidad de visiones, tales como liberales y comunales, capitalistas y no capitalistas, etc.); d) propender por formas de integración regional autónomas en base a criterios ecológicos y de desarrollo autocentrado (no dictado por los requerimientos de la acumulación mundial de capital), a niveles subnacionales, nacionales, regionales, y globales (p. 30).

\section{Respuesta a las críticas del posdesarrollo.}

Teniendo en cuenta que el posdesarrollo es anunciado por autores postestructuralistas como el mismo Escobar, es preciso atender a la historia del desarrollo con el fin de ver cuáles han sido sus avatares. Así es como se anota que:

Durante los últimos 50 años, la conceptualización del desarrollo en ciencias sociales ha visto tres momentos importantes, correspondientes a tres orientaciones teóricas opuestas: teoría de la modernización entre los 50 s y 60 s, con sus teorías aliadas de crecimiento y desarrollo; teoría de la dependencia y perspectivas relacionadas entre los 60s y 70s; y aproximación crítica al desarrollo como un discurso cultural en la segunda mitad de los 80 s y en los 90 s (Escobar, 2006, p. 447). 
Estos tres momentos claramente diferenciados corresponden a los puntos de vista acotados por los diferentes paradigmas a saber, el liberalismo desde su propuesta de la modernización; el marxismo a través de la teoría de la dependencia; y el postestructuralismo a través de la crítica cultural. En este sentido, la era de posdesarrollo plantea desde el postestructuralismo luego de su período de crítica en los ochenta y principios de los noventa, en donde había centrado sus esfuerzos en mostrar que "el desarrollo era un discurso de origen occidental que operaba como un mecanismo poderoso para la producción social, cultural y económica del tercer mundo" (Escobar, 2006, p. 447), pasará a defender las banderas del posdesarrollo y por ende se verá sometido a diferentes críticas.

En este orden de ideas, el posdesarrollo, partiendo del supuesto de que el desarrollo no puede ser el principio de la organización social de la vida, y menos aún debe continuar viéndose exclusivamente bajo los ojos occidentales, pasa a ser entendido por la corriente postestructuralista como una revalorización de las culturas vernáculas que da valor a los movimientos sociales y a las movilizaciones (Escobar, 2006). Como lo nota Escobar, se pueden destacar tres críticas al posdesarrollo:

(1) con su concentración en el discurso, los defensores del post-desarrollo pasaron por alto la pobreza y el capitalismo, los cuales son los problemas reales del desarrollo; (2) ellos presentaron un punto de vista muy generalizado y esencialista del desarrollo, mientras en realidad hay bastas diferencias entre estrategias de desarrollo e instituciones; y (3) ellos romantizaron las tradiciones locales y los movimientos sociales, ignorando que lo local está también incrustado en las relaciones de poder.

Sin embargo, a pesar de que estas críticas parecen devastadoras, Escobar valiéndose de la corriente postestructuralista responde diciendo que: en primer lugar no pasa por alto la pobreza y el capitalismo, pues es falso el supuesto de que el discurso no es material, ya que el mismo capitalismo es simultáneamente un sistema de discurso y de práctica; en segundo lugar se admite la importancia de esta crítica y se aduce que el proyecto postestructuralista al resaltar la naturaleza y los efectos del discurso del desarrollo en general no busca proveer una representación más precisa de lo real, sino mas bien cuestionar el modo como el discurso ha generado consecuencias sobre el mundo real; y en tercer lugar, se muestra que la última crítica parte de un realismo crónico de académicos que etiquetan invariablemente como 
romántica cualquier crítica radical de occidente o cualquier defensa de "lo local" (Escobar, 2006).

Igualmente, Escobar (2005b) agrega que la noción "realista" de los paradigmas liberales y marxistas no logra desprender la visión de cambio social de las comunidades, llevando a suponer que los expertos del desarrollo conocen $a$ priori lo que la gente necesita y desea. De manera que el postestructuralismo no es que busque romantizar las tradiciones locales, sino que parte del supuesto de que "el otro" es diferente; que "el otro" tiene una concepción diferente de sus necesidades y deseos; y por ende que es importante darle espacio a las comunidades para que éstas se expresen y manifiesten cuáles son sus deseos antes de imponerles algo ajeno a su cultura y sus tradiciones (p. 24).

Sin embargo aún cuando el debate durante los años noventa como lo nota Escobar no se zanjó en favor del postestructuralismo, al menos se abrió espacio a un diálogo inter-paradigmático desde el que diferentes autores han adoptado constructivamente elementos de diferentes tendencias:

Este es el caso particularmente en torno a una serie de cuestionamientos que incluyen los siguientes aspectos: la impugnación del desarrollo en espacios locales (nuevamente, como lo ilustra el caso de PGN); la reconceptualización de movimientos sociales desde la perspectiva de redes y articulaciones locales/ globales; un nuevo acercamiento entre economía política y análisis cultural en lo que concierne a asuntos de desarrollo (es decir, el hecho que algunos economistas políticos de orientación marxista también han comenzado a pensar la cultura como variable importante en sus análisis); y, el análisis de la relación entre desarrollo y modernidad como un modo de profundizar y llevar a cabo en mayor detalle las críticas culturales de los postestructuralistas sin pasar por alto las contribuciones de las críticas liberales y marxistas (Escobar, 2005b, p. 25).

En consecuencia, siguiendo el lema del Foro Social Mundial se puede decir que los debates de los años noventa han contribuido a pensar que "otro desarrollo es posible"; un desarrollo en el que sea cuestionado el dominio del conocimiento de los expertos sobre el conocimiento de las comunidades y los movimientos sociales (Escobar, 2006).

\section{La política deliberativa}

El segundo marco teórico de esta investigación se configura en el marco de la siguiente pregunta: ¿Cómo es posible organizar la comunidad negra en el marco de una lógica liberal? o como lo sugiere Oslender (2008) “CCómo 
sensibilizar a la gente hacia una figura política como el consejo comunitario, cuya lógica occidental es básicamente ajena al entendimiento tradicional de hacer política en los ríos del Pacífico?" (p. 229). Sin lugar a dudas, hay un problema en la manera como la ley establece que los pueblos del Pacífico deben organizarse para proteger los territorios ancestralmente habitados, pues se intenta implantar un modelo liberal en un sistema no liberal.

Bajo estas circunstancias y conociendo las motivaciones que llevaron a elegir este segundo marco teórico, el primer apartado de lo que sigue centrará su atención en las críticas que se le pueden hacer a la democracia liberal; para luego en un segundo apartado establecer los constructos sobre los que se cimenta la concepción deliberativa de la democracia. Vale aclarar que esta conceptualización servirá - en el tercer capítulo- para mostrar los problemas de la organización liberal de los consejos comunitarios y pensar en un modelo alternativo que sirva de base para estructurar la organización de las comunidades negras en el Pacífico.

\section{Gríticas a la democracia liberal.}

En orden a establecer los vacíos y problemas de la democracia liberal será preciso indagar por las críticas que desde diferentes vertientes se han planteado. De manera que, aun cuando en el horizonte se buscará asimilar un modelo deliberativo, no sobra decir que la superación del modelo liberal acepta cuestionamientos desde otras orillas. Es el caso justamente de la vindicación que Andrés Hernández (2002) plantea en su texto; allí el autor desde una perspectiva republicana adoptó una postura distante de la tradición liberal identificando sus limitaciones y restricciones.

Se podrá recusar la referencia a este trabajo arguyendo que no puede ser legítima la defensa de un modelo deliberativo, sobre la base de una crítica republicana. Sin embargo, basta afirmar que muchos de los sesgos que encuentra Hernández (2002) son compartidos también por la mirada posliberal. Sin ser suficiente con esta salvedad, este apartado continuará luego con la lectura que sobre el tema presenta Habermas (1999) en el capítulo "Tres modelos normativos de democracia" de su libro La inclusión del otro.

Creyendo así zanjar las dudas sobre la licencia en la crítica que se plantea, será prudente atender luego a la diferenciación que José Rubio Carracedo (2007) presenta entre la concepción de la ciudadanía desde el 
liberalismo negativo y la concepción de la ciudadanía desde el liberalismo positivo. Ciertamente aquí no se atenderá puntualmente a una crítica por parte del autor, sino más bien a una diferenciación, que luego iluminará los vacíos y problemas de la ciudadanía dentro de la democracia liberal. Un tema de suma importancia en el marco de una investigación sobre los consejos comunitarios, pues una cosa es el prejuicio liberal de la ley, y otra muy diferente las dinámicas organizativas étnicas; una puja que quizás pueda ser comprendida desde la dicotomía entre estas dos concepciones de la ciudadanía.

Así las cosas se espera cerrar este apartado con un texto clásico de Philippe Schmitter (2005) en el que el autor convencido de que el "el fantasma de la democracia posliberal recorre Europa" se dispone a presentar cinco corazonadas de lo que él piensa que va a suceder con la democracia liberal. El trabajo de este autor norteamericano nos dejará en el terreno de un nuevo modelo de democracia; un modelo que supere los rezagos del liberalismo un modelo de la democracia deliberativa que precisamente será el que se presentará en el siguiente apartado.

Retomando el trabajo de Andrés Hernández (2005) se pueden identificar dos problemas básicos en el liberalismo: la representación imperfecta y los problemas de agencia, favoritismo y corrupción. Así que siguiendo la argumentación del autor se busca desentrañar estas dificultades sin caer en una propuesta republicanista.

\section{El problema de la representación.}

La representación en sí misma genera dificultades debido a que no presupone un trato igual hacia todos los individuos, sino que más bien establece una diferenciación entre quienes gobiernan y quienes son gobernados. Tan es así que se podría pensar que el Gobierno representativo se estableció como una forma de Gobierno diferente a la democracia, pues ciertamente connota un carácter elitista y aristocrático en la medida que las elecciones habilitan a unos para ostentar el poder sobre otros. Pero se podría reponer que son precisamente las elecciones las que legitiman el poder al otorgarles el derecho de mandar a los gobernantes lo cual es completamente cierto; solo que los comicios por su naturaleza no logran eliminar las diferencias entre gobernantes y gobernados. Incluso como lo anota Hernández (2002). 
[...] uno de los móviles que guiaron la creación de los gobiernos representativos fue la de establecer un sistema político que mantuviese alejados a los ciudadanos de la política, y que impidiera convertir a los representantes en mandatarios de la voluntad popular (p. 534).

Arguye Hernández que los padres fundadores de la democracia no solo eran consientes de la separación que se daba entre representantes y representados, sino que además defendían el Gobierno representativo en rechazo de una dictadura de las mayorías ${ }^{4}$. En otras palabras, el sistema representativo se ideó deliberadamente como una estrategia para separar a los gobernados de los gobernantes y así evitar los excesos de un Gobierno directo en el que una gran mayoría de ciudadanos cooptaría a otros a seguir su voluntad. Esto queda más claro si se tiene en cuenta que uno de los argumentos en favor de la democracia representativa es que ésta logra incluir a más ciudadanos electos y una mayor porción del territorio. Pero al respecto conviene aducir que de momento no interesará profundizar en la eficacia de este modelo de Gobierno - esto se hará en el tercer capítulo donde se revisará en relación con los Consejos Comunitarios--, en tanto que lo que interesa es demostrar que la democracia representativa si justifica la separación entre gobernantes gobernados y lo hace sobre la base de dos argumentos: la extensión del territorio -y la consecuente cantidad de individuos- y la dictadura de las mayorías.

El único problema de la democracia representativa no es la separación entre gobernantes y gobernados, también se puede decir que esta forma de Gobierno no logra incluir todas las voces e intereses y contrario a las motivaciones de los padres fundadores de la democracia - entre ellos Madison-, no se producen decisiones imparciales. Antes bien, se da como resultado una imposición de la voluntad de las mayorías sobre los intereses de las minorías, que con una pobre o nula representación se ven sujetas a las decisiones del mayor número. En palabras de Hernández (2002) "esta incapacidad estructural de las democracias liberales para asegurar una representación plena de todos los sectores y voces de la sociedad, afecta principalmente a los grupos más débiles y a las minorías étnicas, religiosas, sexuales, raciales" (2002, pp. 543).

Hernández (2002), siguiendo a Madison, sostiene que la "tiranía de las mayorías", o tiranía legislativa, no es menos grave que la tiranía de la minoría, o tiranía del ejecutivo. Según él las dos son producto de la falta de controles externos y por ende son igualmente indeseables. Una argumentación muy cercana a la de John Stuart Mill (1998) hablará de la "dictadura de las mayorías". 
Otro más de los problemas de la representación es la tendencia a la burocratización, que sin lugar a dudas conduce a la oligarquización de los partidos políticos de la que habla Robert Michels y que según Hernández (2002) puede ser explicado por dos factores:

Los primeros, las razones motivacionales de los líderes y de las masas. Los factores psicológicos, como el egoísmo desmedido, la consciencia entre líderes de su propia valía, el deseo de poder y ambición, la apatía de las masas y su posible sumisión [...] Los segundos son los factores derivados de la evolución y las necesidades de la organización: el crecimiento y complejidad de las tareas, la división del trabajo, el crecimiento de la organización, la necesidad de decisiones rápidas, las exigencias de una actividad de tiempo completo y el desarrollo de conocimientos especializados que conduce a la necesidad de un liderazgo estable, a su profesionalización, a la superioridad; la tendencia a escoger soluciones de rutina (p. 547).

De este modo, la burocratización de la democracia liberal lleva a fenómenos como la estandarización de cargos con profesionales, tareas específicas y remuneración fija; así como también conduce a la centralización de la autoridad y el consecuente sacrificio de la voluntad de los miembros de la base que pierden vocería en los procesos de toma de decisión. En estos términos, sobra agregar que el problema de la representación en la democracia liberal es quizás de los aspectos más relevantes a tener en cuenta en el examen de los consejos comunitarios.

\section{Los problemas de agencia, favoritismo y corrupción.}

El trabajo de Hernández (2002) resulta prolífico en la tipificación de los problemas de la democracia liberal, pues no solo se queda en la representación sino que prosigue con otras dificultades más. Es el caso entonces de la agencia que en palabras del mismo autor se refiere al hecho de que los gobernantes no cumplen con las propuestas que hacen, y en lugar de buscar los intereses públicos persiguen intereses propios. En estos términos, se plantea que la razón de que esto suceda se halla en que no existen contratos entre electores y representantes que obliguen a estos últimos a cumplir con la agenda programática. Lo cual quiere decir que las comunidades de base tienen pocos medios para obligar a sus representantes a cumplir con lo que prometen. Pero lo más grave de este incumplimiento es que en muchas ocasiones no depende de la voluntad del representante sino del funcionamiento 
mismo de las instituciones liberales, pues "los políticos se mueven en un mercado político guiado por intereses y presiones privadas, y no solo por objetivos públicos” (Hernández, 2002, p. 549).

Bajo estas circunstancias, si el ciudadano no tiene forma de evaluar la gestión de los gobernantes ni tampoco tiene herramientas para distinguir la calidad y el cumplimiento efectivo de sus propuestas; ciertamente como lo aduce Hernández (2002) se producen incentivos para que los representantes defrauden al elector y persigan sus intereses personales. Pero lo más complejo de la situación tiene que ver con el fenómeno del favoritismo que en el marco de la democracia liberal se manifiesta a través del clientelismo y amiguismo: "en los dos casos, los políticos y los tecnócratas tienen incentivos para responder a los grupos de presión más importantes y organizados, o a aquellos que fueron leales electoralmente o programáticamente" (p. 550). Esto quiere decir, que la falta de un control a la gestión produce incentivos para el amiguismo que a su vez tiene como consecuencia la corrupción. En otras palabras, si no hay un control a la gestión el representante puede promover ventajas ilícitas entre quienes lo eligieron o entre los grupos de presión.

Luego de hacer referencia a la lectura crítica que sobre la democracia liberal plantea Andrés Hernández, es preciso exponer el punto de vista de Jürguen Habermas. No se debe dejar de lado el hecho que la primera crítica se hace desde la orilla del republicanismo. No obstante, sobra agregar -como ya se planteó antes- que la democracia deliberativa no conflictúa con las críticas republicanas, pues de lo que se aleja más bien es de la sobrecarga ética del modelo que expone. En estos términos se aludirá a la crítica que Habermas (1999) aborda a la democracia liberal y las razones por las cuales se rechaza esta sobrecarga ética.

Para Habermas (1999) son tres los diferendos que se dan entre el liberalismo y el republicanismo. El primero se refiere al concepto de ciudadano, el segundo al concepto de derecho y el tercero al proceso de formación de la voluntad política. Mientas que el liberalismo entiende la ciudadanía desde el punto de vista de los derechos subjetivos negativos -libertad como no coacción- que garantizan un ámbito de elección dentro de un espacio en el que las personas jurídicas están libres de una coacción externa; el republicanismo aduce que la ciudadanía se determina en los derechos de participación y co- 
municación, en tanto son derechos positivos -Libertad como autonomía- ${ }^{5}$. En cuanto al concepto de derecho:

Mientras que para la concepción liberal el sentido de un ordenamiento jurídico consiste en que permita determinar en cada caso qué derechos les corresponden a qué individuos, de acuerdo con la concepción republicana, estos derechos subjetivos se deben a un ordenamiento jurídico objetivo que hace posible, a la vez que garantiza, la integridad de una vida en común, autónoma en igualdad de derechos y basada en el respeto recíproco (pp. 234-235).

El proceso de formación de la voluntad política separa los dos modelos de democracia al suponer para el liberalismo una competencia entre actores colectivos en orden a adquirir posiciones de poder y representar para el republicanismo una posición en favor del diálogo y en rechazo del mercado político. Es así, como este segundo modelo se acerca a la democracia deliberativa al suponer que los partidos que luchan por posiciones de poder dentro del Estado deben aceptar el estilo conclusivo de los discursos políticos; es decir una actitud propicia al diálogo en la que se esté dispuesto a ser persuadido por las razones del otro (Habermas, 1999).

Aún cuando el republicanismo logra concretar sus ideas en la deliberación es preciso distanciar su propuesta del modelo de democracia deliberativa en el sentido habermasiano. Para este autor alemán el problema del republicanismo es que "resulta ser un modelo demasiado idealista y hace depender el proceso democrático de las virtudes de los ciudadanos orientados hacia el bien común" (Habermas, 1999, p. 238). En relación con la reflexión se puede afirmar que la carga ética de este modelo suspende las condiciones reales de la política de manera idealista cuando más bien "sí están suficientemente institucionalizadas las correspondientes condiciones de comunicación, la política dialógica y la política instrumental pueden entrelazarse en el medio que representan las deliberaciones" ( p. 239).

Luego de presentar las críticas de la democracia liberal desde la perspectiva del republicanismo y la consecuente separación de este modelo planteado por Habermas, conviene aludir a la lectura que Rubio Carracedo (2007) presenta

\footnotetext{
Ernst Tugendhat (1998) en uno de los trabajos más claros sobre el tema, afirma que hablar de derechos negativos implica hablar de derechos civiles y políticos, que simplemente prohíben la interferencia del gobierno, mientas que hablar de derechos positivos refiere a los derechos sociales y económicos, que, a diferencia de los anteriores, obligan al gobierno a intervenir en la provisión de bienes y servicios a la ciudadanía.
} 
sobre la ciudadanía desde la perspectiva del liberalismo positivo y negativo. A su juicio, la diferencia entre estos dos modelos radica en que el primero se orienta hacia el desarrollo en el sentido progresista de la libertad positiva; y el segundo se orienta a los derechos subjetivos y el individualismo desde el punto de vista de la libertad negativa. El autor presenta cinco variables de comparación, pero teniendo en cuenta el horizonte de nuestra indagación -los consejos comunitarios del medio Atrato- sólo se tendrán en cuenta tres: el individualismo, la participación política y el Estado.

Uno de los rasgos más distintivos del pensamiento liberal es el individualismo producto del discurso contractualista de la modernidad. Desde el punto de vista del liberalismo negativo la sociedad se comprende como la agregación de preferencias individuales y el Estado se limita a cumplir una función instrumental garantizando los derechos individuales y castigando las interferencias. El liberalismo positivo; por su parte niega que la autonomía individual sea un obstáculo para la cooperación social, pues como lo sostiene Rubio Carracedo (2007) en alusión a la distinción que Rawls hace entre lo racional y lo razonable: "no hay contrato sin 'racionalidad', esto es, sin ventaja individual; pero tampoco lo hay sin 'razonabilidad'; esto es, sin imparcialidad, sin lealtad a unas normas comunes vinculantes para todos" (p. 71).

En cuanto a la participación política, el punto de separación entre las dos vertientes del liberalismo radica en la posición activa y pasiva del ciudadano. La vertiente negativa promueve una visión instrumental de los derechos políticos, a través de una ciudadanía ignorante y apática; en tanto la positiva aboga por una ciudadanía consciente, autónoma y vigilante. No hay duda de que la representación es el problema que se cierne entre las dos concepciones de la ciudadanía; pues como ya lo había mostrado Hernández y como lo enfatiza Rubio Carracedo el modelo representacional conduce a un escenario clientelar en el que los agentes negocian siguiendo la lógica del beneficio particular. El problema es que:

El mercado político no puede inhibirse de la realidad de las comunidades políticas, en las que el estado ha de conjugar no solo preferencias individuales sino compatibilidades entre los intereses e incluso la consecución de un bien común para todos (Rubio, 2007, p. 74).

Sobre el Estado se dice que el liberalismo negativo sostiene una neutralidad frente a cualquier concepción particular de bien y frente a cualquier 
moral omnicomprensiva; lo cual significa una primacía de lo justo sobre lo bueno. Por su parte el liberalismo positivo hace que prevalezca la dimensión cívica en dos versiones diferentes: por un lado desde la concepción rawlsiana de los "principios de justicia", y por otro lado desde la concepción habermasiana de la "deliberación pública en condiciones normativas". De manera que se contrapone la prevalencia de la esfera privada en términos del bien individual, con la prevalencia de la comunidad política en función del bien público (Rubio, 2007).

Dicho lo anterior quedan por señalar las corazonadas que Phillippe Scmitter (2005) presenta respecto al futuro de la democracia liberal. Estas corazonadas son producto de una inferencia perspicaz: "un [nuevo] espectro recorre Europa -el espectro de la democracia post-liberal" (p. 249). Esto quiere decir que el autor norteamericano cree que la democracia liberal está sustentada sobre la base de unos dilemas que le son intrínsecos y que hacen pensar que en un momento histórico como el nuestro - caracterizado entre otras cosas por la globalización- su implementación resulta impracticable y hasta anacrónica. El punto de vista de este autor es distante en ciertos aspectos de la propuesta deliberativa de democracia; sin embargo se cree pertinente atender a las razones que hacen ver la caducidad del sistema liberal, pues aunque ya se han visto los problemas no se han definido las razones por las que se podría pensar en un futuro en el que esta forma de gobierno ya no rigiera hegemónicamente las democracias del mundo.

La primera corazonada tiene que ver con el hecho de que las democracias liberales establecidas serán juzgadas severamente por sus ciudadanos ocasionando problemas de legitimidad; la segunda corazonada es que al ser juzgadas, lo que se pondrá en cuestión será el carácter liberal y no el democrático; la tercera corazonada postula que dado el carácter incierto y tumultuoso de la democracia liberal, el fin de esta forma de gobierno no provendrá de alternativas autocráticas sino de la reafirmación de los fundamentos de la teoría democrática; la cuarta corazonada es que la alternativa más atractiva es la de la democracia post-liberal, aún a pesar del afianzamiento del liberalismo visto a través de la privatización de empresas y la eliminación de regulaciones estatales; y finalmente la quinta corazonada es que el régimen liberal no puede transformarse hasta que aparezca una alternativa y esta sea conocida por un número importante de actores. Así que el reto de la demo- 
cracia posliberal es trasformar el "espectro" en modelo, haciéndolo plausible para los actores políticos (Schmitter, 2005).

En conclusión, se puede afirmar que el modelo de democracia liberal es perecedero frente a la realidad política contemporánea y por ende los modelos de democracia posliberal se instituyen en la vía de la renovación de las formas de gobierno. Está condenado a extinguirse, no solo por el hecho que se plantean nuevas alternativas, sino también por que principios como la representación, la agencia o la ciudadanía dejan en evidencia un modelo elitista que choca con una realidad en la que el actor político se quiere hacer partícipe de las decisiones,sobre todo si se tiene en cuenta un actor reivindicativo como por ejemplo el consejo comunitario.

\section{Los postulados de la democracia deliberativa}

Más que reconstruir el planteamiento teórico de autores como Rawls o Habermas lo que se pretende hacer en este apartado es dar a conocer una visión amplia de lo que se ha llamado democracia deliberativa. Esto quiere decir que aun cuando sus planteamientos serán retomados, no serán los únicos a tener en cuenta dentro de la conceptualización por el contrario, se espera incluir visiones poco convencionales que den luz a nuevas miradas sobre esta concepción posliberal. En este sentido se tendrán en cuenta aspectos que puedan ser relevantes al momento de proponer un modelo alternativo de organización para las Comunidades Negras en el Pacífico.

Para comenzar resulta conveniente atender a una justificación del tránsito de un modelo liberal de democracia a un modelo deliberativo. Para Roberto Gargarella (2001) la necesidad de repensar el modelo de Gobierno radica en la misma pregunta que se plantearon los "padres de la democracia" “Címo deberíamos organizar los sistemas políticos a fin de lograr decisiones imparciales?" (p. 323). No hay duda que en la actualidad el sistema político tiene problemas para garantizar decisiones imparciales, pues no son tenidos en cuenta los puntos de vista de todos los actores políticos. Ciertamente el problema radica en las dimensiones de la democracia contemporánea; teniendo en cuenta que los argumentos liberales precisamente aducían la necesidad de la representación con el fin de evitar la cooptación de la voluntad de las minorías, es preciso afirmar siguiendo a Gargarella (2001) que el problema 
Los consejos comunitarios del medio Atrato en la vía del posdesarrollo Hacia un modelo deliberatorio de organización de las comunidades negras

ahora radica en que el sistema político no logra asegurar la plena representación de la sociedad.

Bajo estas circunstancias siguiendo al filósofo argentino es posible afirmar que la deliberación ayuda a resolver el problema de la imparcialidad. Primero porque se promueve el conocimiento de las preferencias y los intereses del otro de cara a evitar decisiones parciales por causa de la ignorancia; segundo porque el individuo debe estar en la obligación de modificar su argumento a fin de volverlo aceptable para otros ${ }^{6}$; tercero porque al promoverla en la educación se adecúan los comportamientos de la gente con el fin de escuchar los argumentos ajenos; y cuarto porque permite a cada participante aclarar y purificar su propia posición (Gargarella, 2001).

Ahora bien, si se tiene en cuenta que la democracia deliberativa presupone una superación del liberalismo es preciso afirmar siguiendo a Amartya Sen (2009) que la idea de democracia ha vivido un gran desplazamiento a partir de las obras de Rawls y Habermas. De manera que es cada vez más común encontrar en la teoría política contemporánea una ampliación del concepto formal de democracia, entendido a partir de elecciones y votos, por una concepción en la que prima de manera acuciosa la discusión. Es así como empieza a hablarse del "gobierno de la discusión", que en Rawls - desde el punto de vista de Sen- se manifiesta a través de la democracia deliberativa y en Habermas a través del razonamiento público. El primero supone que "la idea definitiva de la democracia deliberativa es la idea misma de deliberación. Cuando los ciudadanos deliberan, intercambian opiniones y debaten sus razones en favor de cuestiones políticas públicas" (Sen, 2009, p. 355); y el segundo sostiene que el "razonamiento público" supone una presencia dual en el discurso político de las cuestiones morales de la justicia y las cuestiones instrumentales de poder y coerción. En términos del mismo Habermas (1999) la política dialógica y la política instrumental pueden en-

\footnotetext{
Según Gargarella (2001) una de las virtudes de la deliberación tiene que ver con que permite reconocer los argumentos interesados, es decir, aquellos argumentos que tienen por objeto un interés personal escindido de la "razonabilidad" de la que hablará Rawls. En palabras de Gargarella "no es probable que las propuestas que tengan su fundamento en los nombres propios (hay que hacer esto porque beneficia a María) o que hacen referencia a intereses particulares (hay que hacer esto porque beneficia a los propietarios de esta casa) o a razones no universales (hay que hacer esto porque me gusta) prosperen en ninguna asamblea genuinamente deliberativa" ( p. 324).
} 
trelazarse y no mantenerse escindidas, pues de hacerlo se partiría de unas condiciones inexistentes de la democracia que harían irrealizable el modelo.

A Sen (2009) no le interesa acentuar la dicotomía entre estos dos autores, más bien lo que le interesa es dejar de presente que existen muchas formas de entender el razonamiento público en la política y en la ética discursiva. En sus palabras "lo más importante es señalar que todas estas nuevas contribuciones han ayudado a promover el reconocimiento general de que las cuestiones centrales en una comprensión amplia de la democracia, son la participación política, el diálogo y la interacción pública” (p. 356). Lo cual quiere decir que aunque los votos y las elecciones tienen una función muy importante en la expresión del proceso de razonamiento público, "votar a secas puede ser en sí mismo completamente inadecuado, como lo muestran con elocuencia las insólitas victorias electorales de tiranías en ejercicio o regímenes autoritarios del pasado y del presente" (Sen, 2009, p. 357). Votar no debe significar únicamente sufragar, pues el juego en las urnas representa también libertad de expresión, acceso a la información y derecho a disentir.

En estos términos, Oscar Mejía (2010) sostiene que la Teoría de la fusticia de John Rawls puede ser entendida como una crítica a la democracia liberal decimonónica; en tanto que opone un modelo de mayorías a un modelo consensual, según el cual parte de una posición original y de allí "se derivan, en condiciones simétricas de libertad e igualdad argumentativas, unos principios de justicia que orientan la construcción institucional de la estructura básica de la sociedad, a nivel político, económico y social” (p. 46).

Rawls (1996) sostiene una concepción de la justicia como imparcialidad en relación con los principios de justicia y la posición original. De manera que buscando aludir al modelo consensual del que habla Mejía se retomarán de la Teoría de la justicia $(1971)^{7}$ tres aspectos que se cree pueden iluminar la posterior concepción de la democracia deliberativa. El primero es la posición original; el segundo, la elección de los dos principios de justicia dentro de una situación de incertidumbre -en la posición original-; y por último la aplicación práctica de los dos principios de justicia (teniendo en cuenta que se aclara más el primero) dentro de una sociedad. Estos tres ejes temáticos se articulan dentro de un único horizonte de sentido que se refiere por un lado

Es importante aclarar que la edición del libro de la Teoría de la Justicia que será citado no es del año 1971, sino del año 1996. 
al establecimiento legítimo de los principios de justicia, como mejor forma de alcanzar el objetivo de la justicia social; y por otro lado a su implementación dentro de una sociedad concreta.

La descripción de la posición original se presenta en relación con el velo de ignorancia y la racionalidad de las partes en la elección de los principios de justicia. En cuanto al primero se puede decir que cada una de las partes no conoce su lugar en la sociedad, ni su suerte en la distribución de talentos, ni su concepción del bien, ni las condiciones particulares de su propia sociedad, ni tampoco las contingencias que llevan a los hombres a oponerse entre sí, aunque sí conoce los hechos generales de la sociedad humana, las cuestiones políticas y los principios de la teoría económica y las bases de la organización social y las leyes de la psicología humana. En cuanto a la segunda, se puede anotar simplemente que en la posición original los hombres son racionales y buscan tener más bienes sociales primarios, sin importarles lo que tengan los demás (Rawls, 1996).

La elección de los principios de justicia se puede aclarar en relación con la solución maximin al problema de la justicia social en situaciones de incertidumbre. Según ésta "habremos de adoptar la alternativa cuyo peor resultado sea superior al peor de los resultados de las otras alternativas" (Rawls, 1996, p. 150). De este modo, las partes escogen los principios de justicia sobre los puntos de vista tradicionales; en tanto que éstos cubren los rasgos característicos de la regla maximin, es decir, no se tiene conocimiento de las alternativas posibles (velo de ignorancia). La concepción del bien que tienen las partes hace que les importe muy poco lo que se pueda ganar por encima del mínimo de la regla (Mínimum satisfactorio de libertad frente a ventajas económicas) y las alternativas rechazadas sustentan resultados inaceptables (otras concepciones de justicia llevan a instituciones intolerables). Estos principios de justicia elegidos sustentan entonces dos tipos de ventajas; una en relación con el rigor del compromiso con el que se garantiza la protección de las libertades básicas; y dos, el carácter público que favorece una concepción de justicia estable que apoya el respeto a sí mismo.

La aplicación práctica de los principios de justicia a su vez se establece en dos momentos:

Momento 1. Principios de fusticia: se presenta una secuencia de cuatro etapas en las que la primera es la posición original, en donde se adoptan los princi- 
pios; la segunda es un congreso constituyente donde se elige la justicia de las formas políticas y la constitución; la tercera es una etapa legislativa donde se formulan las leyes en relación con la política económica y social; y la cuarta, una etapa en la que se aplican las reglas a casos particulares y los ciudadanos obedecen las reglas (Rawls, 1996).

Momento 2. Principio de igual libertad: se define primero la estructura básica bipartita, en relación con una libertad equitativa para todos (igualdad cívica), y un valor de la libertad desigual (permitido por el principio de la diferencia) en relación con quienes tienen más capacidad para promover sus fines. Continuando luego, con la argumentación en torno a la instauración de la libertad de conciencia, y cerrando finalmente con el interés común como único limitante de la libertad, la protección de la constitución y las instituciones como mecanismo para garantizar la igualdad de la libertad en casos de extrema peligrosidad (Rawls, 1996).

Ahora bien, con base en los presupuestos de la Teoría de la fusticia, es preciso dar paso al texto clásico de Rawls (2004) sobre el asunto de la deliberación pública: El liberalismo político (1993)8. Mejía (1994) establece que el móvil que persigue el filósofo norteamericano en este texto tiene que ver con la búsqueda de la concepción más apropiada para especificar los términos de la cooperación social entre ciudadanos libres e iguales en el marco de una cultura democrática marcada por una diversidad de doctrinas. Móvil que el autor logra concretar en la idea de un consenso entrecruzado

Como parece claro, el consenso entrecruzado que plantea Rawls, es el amplio consenso que puede establecerse en torno a los principios de la justicia definidos por su concepción de Fustice as fairness. Estos nos permiten, por la trasparencia procedimental y la legitimidad moral que la sostiene, convocar el respaldo de todos los grupos sociales con concepciones omnicomprensivas, los cuales ven en ellos macrovalores políticos suficientemente amplios como para apoyarlos en tanto garantizan, para todos y cada uno, una estructura básica justa e imparcial que permite la estabilidad del sistema democrático y la pluralidad de posiciones a su interior (Mejía, 1994, p. 80)

Es así que el mismo Rawls (2004) aduce que "en una sociedad política con un consenso de esta clase, varias concepciones de la justicia serán rivales políticas, y sin duda las favorecerán diversos intereses y estratos políticos" (pp. 163-164). De manera que no hay la menor duda de que una sociedad en

Es importante aclarar que la edición del libro del Liberalismo Político que será citado no es del año 1993, sino del año 2004. 
la que se garantiza un consenso entrecruzado, es una sociedad en la que la "justicia como imparcialidad" tiene un lugar privilegiado.

Dicho esto, cobra relevancia el planteamiento de Cohen (2001), según el cual la autorización para ejercer el poder estatal debe surgir de las decisiones colectivas de miembros iguales de una sociedad. Algo similar a lo planteado por Sen (2009) en relación con el "gobierno de la discusión". Pero en términos de Cohen se diferencia en la medida que para lograr estas decisiones colectivas pueden establecerse dos vías: una agregativa y otra deliberativa:

De acuerdo con la concepción agregativa de la democracia, entonces, las decisiones son colectivas siempre que surjan de disposiciones de elección colectiva vinculante que otorguen igual consideración (mas genéricamente, que sean positivamente sensibles) a los intereses de cada persona vinculada por las decisiones. De acuerdo con la concepción deliberativa, una decisión es colectiva siempre que surja de disposiciones de elección colectiva vinculante que establezcan condiciones de razonamiento libre y público entre iguales que son gobernados por las decisiones (Cohen, 2001, p. 236).

Según Cohen (2001) en el marco de la democracia deliberativa los individuos se tratan como iguales en la medida que ofrecen mutuamente justificaciones para el ejercicio del poder. Lo que quiere decir que no se trata solamente de propiciar una cultura pública de "discusión razonada", sino de "vincular de modo manifiesto el ejercicio del poder a condiciones de razonamiento público", es decir, la generación de un "poder comunicativo" a partir de la formación discursiva de la voluntad y la opinión pública. Este razonamiento público no se da exclusivamente en lo político, también se da en el marco de disposiciones sociales e institucionales.

Sin embargo, aun cuando resulta plausible el modelo que plantea Cohen, Habermas afirma que esta imagen de política deliberativa deja un vacío en la relación que se da entre el aspecto formal y el aspecto informal de la opinión y la voluntad; es decir, entre las deliberaciones orientadas por procedimientos democráticos y los procesos de formación de opinión en el espacio público. Al respecto el filósofo alemán arguye que "la política deliberativa se nutre pues, de una interacción entre la formación de la voluntad formalmente articulada en términos democráticos y la formación informal de la opinión" (Habermas, 1998, p. 386). Una articulación que desemboca en la suposición de que la opinión informal conduce a decisiones electorales ins- 
titucionalizadas y a resoluciones legislativas por las que el poder producido comunicativamente se convierte en poder utilizable administrativamente.

De esta forma se llega al eje neurálgico de la propuesta de Habermas y al punto central de la concepción deliberativa de la democracia. Según el filósofo alemán los sujetos solo pueden lograr la autonomía si participan de los procesos de conformación de las leyes y principios del orden determinado. Es decir que los espacios de participación no pueden estar al margen de la toma de decisiones y la formulación de las leyes. En consecuencia; se busca desde esta perspectiva articular la teoría discursiva y la forma del derecho, de manera tal que se logre la mediación entre la moral y la política.

Esto conduce, necesariamente, a una idea distinta de deliberación, según la cual:

[...] los procedimientos y presupuestos comunicativos de la formación democrática de la opinión y de la voluntad funcionan como las esclusas para la racionalización discursiva de las decisiones de un gobierno y de una administración sujetas al derecho y a la ley (Habermas, 1999, p. 244).

Es así como el punto de partida del "proceso legislativo autónomo" termina concentrado en el principio discursivo, que en términos de Francisco Cortes Rodas (1996) considera el medio para establecer un criterio neutral de autonomía y un procedimiento que garantice las condiciones de imparcialidad.

Este principio discursivo supone que "solo son válidas aquellas normas de acción con las que pudieran estar de acuerdo como participantes de un proceso legislativo discursivamente concebido, todos aquellos sujetos de derecho que de alguna forma pudieran ser afectados por dichas normas" (Cortés, 1996, p. 14). Así mismo presupone una separación funcional de las esferas del derecho y la política frente al ámbito de la moral, solo que esta separación no puede producir contradicciones entre los dos sistemas, pues deben estar sujetos a una complementación funcional que debe ser producto de la participación del sujeto en diferentes procesos de conformación de reglas y normas en el mundo práctico.

En este sentido, siguiendo a Cortes (1996) es posible inferir que el principio discursivo es el resultado del entrelazamiento de la teoría discursiva y la forma del derecho. De manera tal que debe servir para fundamentar: 
Los consejos comunitarios del medio Atrato en la vía del posdesarrollo Hacia un modelo deliberatorio de organización de las comunidades negras

1) Que toda persona tiene igual derecho a un régimen suficiente de libertades subjetivas de acción, 2) que cada uno esté protegido para que sus derechos políticos de pertenencia a una comunidad no le sean negados unilateralmente, 3) que a toda persona se le aseguren la igualdad de tratamiento frente a la ley mediante establecimiento de principios básicos de justicia, 4) que los derechos políticos deben garantizar la participación de los ciudadanos en todos los procesos políticos de decisión y consulta para que la libertad comunicativa de cada uno adquiera realidad, y 5) que se debe dar la garantía de unas condiciones de vida técnicas, sociales y ecológicas (p. 15).

De este modo, la concepción deliberativa de la democracia de Habermas (1998) supone, a diferencia de Rawls, que los derechos subjetivos de acción son condición necesaria para el ejercicio de la autonomía política. En otras palabras, sin el principio discursivo como, presupuesto y condición de un proceso deliberativo, no puede haber una verdadera democracia.

Por tanto, para concluir este apartado, basta con anotar que la democracia deliberativa presupone una superación del liberalismo en la medida que responde al problema de la imparcialidad y logra anteponerse a las dificultades de la participación. Lo dicho hasta acá permitirá trazar una hoja de ruta en la transformación de las organizaciones y los movimientos sociales, de tal forma que visiones alternativas, como la de Rawls, Habermas o Cohen - planteadas aquí-, permitan llevar a una comprensión diferente de la participación y por ende de la misma democracia. Es preciso pensar que las comunidades de base deben tomar partido en las decisiones que les competen, pero deben hacerlo de tal manera que el acceso a la esfera pública les sea garantizado9.

\section{Puntos de encuentro: Democracia deliberativa y posdesarrollo}

Teniendo en cuenta que uno de los propósitos de esta investigación es encontrar lógicas explicativas que permitan dilucidar fenómenos sociales como los consejos comunitarios del medio Atrato. Es importante aclarar que este interés explicativo parte de la premisa de entender los pueblos, pero sin

La esfera pública según Nancy Fraser (1997) “designa el foro de las sociedades modernas donde se lleva a cabo la participación política a través del habla. Es el espacio en el que los ciudadanos deliberan sobre sus problemas comunes, por lo tanto, un espacio institucionalizado de interacción discursiva. Este espacio es conceptualmente distinto del Estado; es un lugar para la producción y circulación de discursos que, en principio, pueden ser críticos frente al estado" (p. 97). 
imponer visiones foráneas o perspectivas ajenas a las realidades locales. En otras palabras, imponer visiones occidentales sobre procesos sociales no occidentales. En estos términos, como se mostró previamente, el posdesarrollo se propone, entre otras cosas, rechazar el imaginario del desarrollo y promover lógicas alternativas de producción e inclusión social, pero teniendo en cuenta, que los consejos comunitarios son formas de organización social en las que interceden procesos de elección y decisión.

Se observa que aunque el posdesarrollo es un marco teórico plausible en favor de la autodeterminación de los pueblos, no es claro lo que puede plantear este marco teórico en relación con las formas de organización. Lo que se quiere decir es que los consejos comunitarios, ideados en la Ley 70 de 1993, presentan una lógica liberal de organización que controvierte la dinámica de reivindicación de los derechos étnicos de las Comunidades Negras. Esto se debe a que, por un lado, se reconoce que estos pueblos tienen una tradición, unos valores y unas culturas que los identifican $-\mathrm{y}$ que por ende se respetan- y por otro se dice -implícitamente- que los pueblos no tienen autonomía para organizarse y que por ende deben asumir las lógicas propias del modelo estatal. En consecuencia aun cuando se reconoce la importancia del posdesarrollo en las dinámicas de concertación de los consejos y en la exaltación de las culturas locales, se nota el vacío conceptual al momento de confrontar este tipo de dinámicas organizativas; se ve que son inconvenientes y que deberían fundarse en un modelo que le otorgara autonomía a los pueblos, pero no se ve cómo podría materializarse esta autonomía.

En esta medida, se hace necesario pensar en un modelo de organización alternativo en el que las comunidades sean participes y en el que no se transmitan los vicios del modelo liberal. Es así como se piensa en la democracia deliberativa que, sobre la base de discusión, debe sentar las bases para una auténtica participación. No es que se esté afirmando que en el modelo actual de los consejos comunitarios las organizaciones de base no participen, solo que esta participación se da en condiciones de desigualdad. Normalmente el representante legal o el líder campesino es el más educado o el más conocedor sobre el tema, y por ende, su status de saber le otorga ciertas ventajas en la toma de decisiones de la comunidad; esto sobre la base de un presupuesto de discusión, pues en muchas ocasiones la lógica de la representación termina otorgándole el poder de decisión al representante o a la junta. 
En estos términos, reconociendo que "el actual sistema institucional es estructuralmente incapaz de reconocer y atender los diversos puntos de vista que caracterizan a las sociedades multiculturales modernas" (Gargarella, 2001, p. 399), es preciso pensar en un modelo que suponga que la autonomía individual no es un obstáculo para la cooperación social. En otras palabras, el hecho de que cada uno de los individuos de un colectivo busque sus intereses particulares, no quiere decir que sea imposible llegar a acuerdos como lo sostiene Rubio Carracedo (2007)

Es lo que Rawls presento en su complementariedad entre rational y reasonable: no hay contrato sin racionalidad, esto es, sin ventaja individual; pero tampoco lo hay sin razonabilidad, esto es, sin imparcialidad, sin lealtad a unas normas comunes vinculantes para todos. La sola consideración racional individualista conduce a la desintegración social, ya que solo quedan vínculos legales y coercitivos (p. 71).

Dicho lo anterior, es preciso reconocer que aun cuando el posdesarrollo representa un cambio abrupto en el reconocimiento de otros discursos y otros saberes, no es claro el modo como esta inclusión se puede dar, pues, se quiera o no, las comunidades no sustentan concepciones homogéneas sobre lo bueno aún cuando estén afianzadas sobre discursos étnicos -entre otros-. Es así como la democracia deliberativa se concibe como un modelo ideal en el camino a incluir estos discursos excluidos por el desarrollo y no incluidos, de forma clara, por el posdesarrollo. Por tanto, viendo la necesidad de hallar puentes de comunicación entre estos dos marcos teóricos, a continuación se atenderá, primero, al tipo de relación que hay entre la crítica al liberalismo y la crítica al desarrollo; y segundo, la confluencia entre los postulados del posdesarrollo y los postulados de la democracia deliberativa.

\section{Críticas a la democracia liberal y al desarrollo.}

Las críticas que Arturo Escobar (1996) le lanza al desarrollo desde la perspectiva posestructuralista hacen hincapié en los paradójicos resultados del proyecto trumaniano de llevar los modelos hegemónicos en los países avanzados a los países más pobres. En otras palabras, lo que intenta mostrar el antropólogo colombiano es que las promesas de un mundo más igualitario y más próspero se fueron por la borda de una homogenización cultural, de forma tal que el desarrollo recrudeció los problemas socioeconómicos y transformó profundamente las prácticas culturales objeto de sus políticas. 
De otro lado, las críticas que se le lanzan a la democracia liberal, desde concepciones posliberales y republicanas dejan en evidencia que hay un problema de fondo: no se logra la imparcialidad en la toma de decisiones y la representación no logra abarcar todos los puntos de vista. Pero lo más dramático de la democracia liberal es que los padres fundadores instituyeron la representación como el medio idóneo para resolver el problema de la "tiranía de las mayorías" y contrario a sus cábalas, se acrecentó este fenómeno con el agravante de que la separación entre gobernantes y gobernados acabo por establecer un modelo de burocratización en el que los últimos no se sienten representados por los primeros.

En estos términos el aparato del desarrollo establece una separación entre comunidades y expertos en la que estos últimos, a través de su status de saber, buscan implantar las lógicas occidentales que han funcionado en los países del capitalismo avanzado. Mientras que el modelo liberal de democracia, sobre la base de la representación, presenta una separación entre gobernantes y gobernados, en la que los primeros toman las decisiones sobre la base de la elección de los segundos. Por tanto, se puede inferir que tanto en el desarrollo como en la democracia liberal, esta separación se da en detrimento de las comunidades de base. Ciertamente, el discurso impulsa a pensar en un favorecimiento de las comunidades, por la vía de mejores condiciones de vida y de la inclusión del mayor número de puntos de vista. Pero el resultado es trágico, se imponen las élites y se multiplica la pobreza.

Esto lleva a pensar en los problemas intrínsecos que sustenta la representación en la democracia y que, como se dijo antes, conducen al favoritismo y la corrupción. Ciertamente, la falta de un control político de los gobernados hacia los gobernantes hace que se promuevan favorecimientos de los políticos hacia los electores o hacia gremios económicos. Aunque, en el desarrollo, no se pueden evidenciar los mismos esquemas del liberalismo, si se puede hallar con cierta sorpresa que la pobreza ha aumentado y las condiciones de vida han desmejorado. Hechos que llevan a pensar en esquemas de corrupción dentro del modelo, pues resulta incomprensible que los esfuerzos del desarrollo multipliquen los problemas que se buscan resolver. Quizás la corrupción no es del mismo talante que en el marco político y alude más bien al aparato administrativo, pues es factible que gran parte del presupuesto no llegue directamente a las comunidades sino que sea destinada a los profesionales y técnicos del desarrollo. 
Así las cosas, es presumible pensar que así como en la democracia liberal no se incluyen todos los puntos de vista, de igual manera, en el desarrollo no se tienen en cuenta las visiones de las comunidades al momento de implementar cambios abruptos en sus prácticas vernáculas. Por tanto, teniendo en cuenta que los dos modelos sustentan un grave problema en relación con la inclusión y la imparcialidad, es preciso atender a modelos alternativos en los que se tengan en cuenta las necesidades de los pueblos y las comunidades puedan participar en condiciones de igualdad; estos modelos son el posdesarrollo y la democracia deliberativa.

\section{Postulados deliberativos del posdesarrollo.}

De acuerdo con lo planteado por Arturo Escobar (2008), el posdesarrollo se sustenta en dos dimensiones: una relacionada con los imaginarios y otra relacionada con las propuestas reivindicativas. En lo primero se hace referencia al cuestionamiento del crecimiento económico como meta del desarrollo económico y social al reconocimiento del desarrollo como un discurso moderno y la desarticulación, paulatina, del desarrollo como discurso moderno. Esto implica, en suma, un rechazo a la visión moderna del mundo, según la cual, se impone el individualismo, la acumulación, la ciencia, la técnica y la explotación. Pero el posdesarrollo no se afinca únicamente sobre la negación del desarrollo, también se refiere a una reivindicación de valores, tradiciones y prácticas vernáculas. De manera que, la segunda dimensión sobre la que se funda este marco conceptual alude, afirmativamente, a los siguientes aspectos:

a) reconocer la multiplicidad de definiciones e intereses alrededor de las formas de sustento, las relaciones sociales, y las prácticas económicas y ecológicas; b) el diseño de políticas desde cosmovisiones relacionales, en vez de la cosmovisión dualista dominante; c) establecer diálogos interculturales alrededor de las condiciones que podrían devenir en un pluriverso de configuraciones socio-naturales (multiplicidad de visiones, tales como liberales y comunales, capitalistas y no capitalistas, etc.); d) propender por formas de integración regional autónomas en base a criterios ecológicos y de desarrollo autocentrado (no dictado por los requerimientos de la acumulación mundial de capital), a niveles subnacionales, nacionales, regionales, y globales (Escobar, 2008, p. 30).

Ahora bien, teniendo en cuenta estas características, será preciso atender ahora a la concepción deliberativa de la democracia. Al parecer, es pobre la 
referencia que se puede hacer desde el posdesarrollo, sin embargo, como se mostró antes, hay vacíos que es preciso llenar dado que este último marco conceptual no supone un modelo de organización. En consecuencia, teniendo en cuenta que el primer aspecto señalado alude al reconocimiento de la multiplicidad de definiciones e intereses, es preciso apuntalar el interés organizativo hacia un modelo que reconozca la diversidad. Pues bien, la democracia deliberativa, desde la perspectiva rawlsiana, establece que debe darse un "pluralismo razonable" en la medida que se deben reconocer los discursos de la diferencia sobre la base de una razón práctica. En palabras de Cohen (2001) "estas diferencias plantean una tarea genérica para una descripción de la democracia: explicar cómo las personas, diferentes en tantos aspectos, han de ser reconocidas y tratadas como miembros libres e iguales de una sociedad política" (p. 238).

En cuanto al rechazo de la cosmovisión dualista - dominante/dominado-se puede decir que el diseño de políticas desde concepciones relacionales, presupone un reconocimiento del otro como otro, y por ende, establece un modelo participativo en contraposición a un modelo representativo. En estos términos, es preciso partir de unas condiciones iníciales de igualdad, o al menos debe haber un reconocimiento del discurso del otro. De manera que se debe hacer referencia, o bien, al velo de ignorancia de Rawls, o al principio discursivo de Habermas. Desde el punto de vista del primero, los hombres ponen entre paréntesis sus condiciones particulares y por tanto no buscan acuerdos que los beneficien como sujetos privados; desde el punto de vista del segundo se parte del reconocimiento de que "solo son válidas aquellas normas de acción con las que pudieran estar de acuerdo como participantes en discursos racionales todos aquellos que de alguna forma pudieran ser afectados por dichas normas" (Cortés, 1996, p. 14).

$\mathrm{Al}$ hacer referencia al tercero no está de más agregar que para lograr diálogos interculturales efectivos en los que se reconozcan una multiplicidad de concepciones sobre lo bueno, se debe partir de un escenario en el que se garantice la imparcialidad. Así que teniendo en cuenta que la democracia deliberativa, desde el punto de vista de Gargarella (2001) logra resolver el problema de la imparcialidad, se puede anotar que en la discusión se debe garantizar que las partes aclaren su propia postura y modifiquen su argumento a fin de que los otros lo consideren aceptable. Bajo este presupuesto, se 
presenta un problema en términos del diálogo intercultural, pues si la discusión se debe dar entre sujetos razonables que planteen posturas claramente argumentadas, queda por pensar las condiciones de igualdad de sujetos que no han tenido una formación académica diferencial. En el caso de los consejos comunitarios este problema es trascendente, dado que no solo está la relación del líder con los campesinos, sino también la relación del líder con los empresarios, los políticos y los agentes del desarrollo -por llamar así a los "oenegeros"-. Pero el problema de la articulación entre posdesarrollo y democracia deliberativa en este aspecto, no tiene que ver con falencias en este segundo marco conceptual, sino antes bien con vacíos en la concepción del posdesarrollo, pues la diferencia cultural muchas veces se afianza sobre competencias diferenciales. No se quiere decir con esto que haya inferioridad cultural de las Comunidades Negras, solo que todos los afrodescendientes no tienen tan claros sus valores, tradiciones y practicas vernáculas para así defenderlas frente a posturas diferenciales, lo que hace que sean vulnerables frente a otros discursos. Eso sin contar que el diálogo no se puede producir en condiciones de desigualdad, bajo presupuestos de hambre y necesidad, pues de esta manera se utilizan instrumentalmente los requerimientos del otro para aprovecharse de la situación. Por esta razón, se debe apelar a una "esfera pública" en la cual los actores negocien en condiciones de igualdad.

Finalmente, en relación con las formas de integración regional, se puede sostener que al igual que en los diálogos interculturales y en las relaciones sociales -al interior del grupo- se debe partir de unas condiciones de igualdad y reconocimiento del otro que permitan conciliar formas capitalistas de acumulación con formas extractivas de sobrevivencia - por poner un caso-. Pero al decir esto, se deben matizar dos aspectos, de un lado, la presuposición rawlsiana de que todo contrato debe darse en condiciones de racionalidad y razonabilidad, lo cual quiere decir que no hay contrato sin ventaja individual, pero tampoco sin imparcialidad, ni lealtad a las normas; y de otro lado, se debe reconocer que al interior de un grupo también hay diferencias, lo cual quiere decir que argumentos como la etnicidad no suponen necesariamente que todos los individuos sean iguales. Esto quedará evidenciado en el siguiente capítulo donde se mostrará los diferentes discursos que al interior de las comunidades se sostienen en orden a la reivindicación de los mismos derechos. 



\section{Capítulo 3.}

\section{LOS GONSEJOS GOMUNITARIOS EN EL MEDIO ATRATO DESDE LA PERSPEGTIVA DEL POSDESARROLLO Y LA DEMOGRAGIA DELIBERATIVA}

Ll presente capítulo tiene por objeto establecer un anáClisis de los consejos comunitarios del medio Atrato (Chocó, Colombia), sobre la base de los marcos teóricos, a saber, expuestos en el capítulo anterior, el posdesarrollo y la democracia deliberativa. Es de anotar que la información sobre la cual se funda el análisis corresponde a un trabajo de campo adelantado durante el mes de julio del año 2010 en el municipio de Quibdó. El orden a seguir atiende en primer lugar a las prácticas vernáculas que sustentan la cultura del pueblo negro; en segundo, toma en consideración las concepciones que se tienen sobre la propiedad en el marco de la titulación colectiva; tercero, alude a las diferentes perspectivas que sobre el desarrollo sostienen los miembros de la comunidad; en cuarto lugar, se alude al problema de la organización liberal de los consejos comunitarios; y finalmente, en quinto lugar, se plantean ciertas líneas de lo que podría ser una trasformación de los consejos de cara a incluir todos los puntos de vista, es decir, los lineamientos de un modelo deliberativo de organización de las comunidades negras.

\section{Revaloración de las culturas vernáculas}

Uno de los aspectos que suscita mayor cantidad de interrogantes dentro del proceso organizativo de las comunidades 
negras es el asunto de los valores, las tradiciones y las prácticas culturales. De acuerdo con Eduardo Restrepo (2002) la etnización de las comunidades negras en Colombia se da como resultado de un proceso de relocalización de lo negro dentro de las estructuras de alteridad. Algo que en términos de Peter Wade (2000) alude al hecho de que los afrodescendientes del Pacífico buscan reivindicar el hecho de ser considerados como "otros", en un sentido cercano al de los indígenas. La reivindicación consiste en que hasta el artículo 55 los negros eran vistos como ciudadanos de segunda aún cuando hacían parte de la población general, de manera que en orden a defender su territorio arguyen rasgos de una cultura propia, que en términos generales, se refieren a lenguaje, religión, costumbre, tradiciones y sentimiento de "lugar" (Restrepo, 2009).

Pero, teniendo en cuenta lo anterior, el problema se centra en pensar si las comunidades de la cuenca del Pacífico tienen tales rasgos culturales o si más bien fue un subterfugio para conseguir el reconocimiento de sus derechos territoriales. Quizás pueda parecer superficial este planteamiento, aunque teniendo en cuenta que para Carlos Agudelo (2005) "la figura de las prácticas tradicionales de producción fue una especie de tipo ideal que elaboraron las organizaciones negras y sus asesores para apuntalar la exigencia de sus derechos territoriales" (p. 190), por lo cual se puede sustentar la plausibilidad del cuestionamiento.

Sin embargo, se puede reponer que Agudelo solo se refiere a las prácticas de sostenibilidad del pueblo negro y no a la cultura en general, pero si se sigue su argumentación, más adelante agrega, en relación con la propiedad comunitaria, que:

[...] en cuanto a las formas de apropiación colectiva si bien es cierto que este concepto se apoya en la realidad de uso del territorio y es una categoría política de aproximación al modelo de resguardo, también representa una generalización. La ley no le da suficiente importancia a las formas de apropiación individual (Agudelo, 2005, p. 190).

En estos términos, se puede afirmar que el cuestionamiento en torno a la cultura propia de las comunidades negras es pensable como un recurso para establecer si el Estado solo debió reconocer un derecho territorial por la posesión de las tierras, o un medio para reconocer también la etnicidad. 
Bajo estas circunstancias, el padre Gonzalo de la Torre (30 de julio de 2010), uno de los precursores de las organizaciones comunitarias en el Medio Atrato, sostiene que:

[...] ellos llevan una vida comunitaria al tener un tipo de economía distinta de la capitalista obvio que es mas comunitaria con una economía del intercambio a veces en una población cuando encontraban plata no hay plata, no hay billete más bien hay un intercambio, yo tengo estas cosas te las cambio por esta, tienen formas ya como económicas de compartir por ejemplo la mano cambiada, la mano cambiada es [...] cuando ellos al no tener plata pero necesitan la ayuda o el trabajo de otros dicen deme usted tantos días de trabajo y yo se los devuelvo en días de trabajo [...] tienen sus leyes, tienen todo, porque lo utilizan muchísimo, porque no tienen capital pero tienen ese sistema comunitario, tienen el sistema comunitario ambientado por lo religioso [...] ellos han aprendido como hacer determinadas fiestas ellos con la que organizan comunitariamente para hacer sus alumbrados, se organizan comunitariamente para hacer sus velorios, sus entierros, sus novenas, para hacer sus fiestas patronales eso funciona mucho como con organizaciones comunitarias [...].

Pero lo anterior indica, en términos del posdesarrollo, que las comunidades negras sostienen prácticas económicas diferentes a las del capitalismo a través del interés individual y el lucro. Para Guillermo Arcila (27 de julio de 2010) conocedor del proceso organizativo de estas comunidades y representante local del consejo comunitario de San José, los pueblos del Pacífico no tienen una cultura de acumulación:

[...] muy pocas veces consigue usted un nativo realizando esas actividades porque nosotros no hemos tenido la cultura de la acumulación eso no lo están metiendo y algunos ya lo han asimilado pero la inmensa mayoría todavía no y aquí la gente vive muy del diario, primero, porque no hay actividades industriales que le permitan a usted obtener un empleo digno y que usted a la quincena tiene hay la plática y hace el mercadito y manda y guarda y todo eso; eso ya no se da aquí pero si se da que usted coge la Barequita y se va hoy a Barequear y de repente se hace uno o dos gramos de oro y va y los vende y se compra la comida de ese día y se mete con el resto unos traguitos y se acabó y mañana va y empieza de nuevo eso es muy cultural nuestro [...].

Esto es visto por Zulia Mena (22 de julio de 2010), una abanderada del proceso organizativo, como muestra de que las comunidades del Pacífico solo toman lo necesario para vivir sin causar daños innecesarios a la naturaleza: 
[...] hoy sencillamente estamos usando las cosas que son prestadas y acá nosotros entendemos la familia así; están unos y mañana están otros y no hay que comerse todo hoy. Por eso nosotros en el territorio decimos solo hay que sacar lo necesario para vivir nuestros mayores van al monte y ellos ven dos racimos de plátano y miran cual está bien para hoy y cual dejan para mañana no llevan los dos a la casa y así es todo y por eso usted consigue hoy que a pesar de que hay tanto empobrecimiento la selva permanece ahí porque van a cortar madera y no tumban todos los arboles van cortando por partes, pero los que ya tiene su idea de la ganancia que lo privado van y arrasan con todo.

Sin embargo, como lo sostiene Agudelo (2005) buena parte de las practicas de producción de las comunidades negras están lejos de ser sostenibles y la idea de que su economía es de subsistencia, termina siendo una generalización acrítica. Al respecto cabe aclarar que las prácticas económicas y de producción, no solamente se asientan sobre dinámicas culturales de facto, sino que además se hallan articuladas a una concepción profunda del territorio

[...] el pueblo negro sin territorio no es nadie [...] la Comunidad Negra tiene dos formas de apropiar su territorio: una forma es el tronco familiar que tiene sus varios lotes en diferentes áreas de donde viven y otro es el bosque, que el bosque es usado por toda la gente que vive en una comunidad, que la gente tiene su lote familiar y cultiva allí pero el $70 \%$ del año no permanece usando el bosque [...] la gente trabaja aquí, descubre aquí y todo lo demás lo deja, no cortan los árboles porque los árboles son una forma de protección para el suelo y para hacer la regeneración del suelo se usa el tumba y pudre, desde las mismas hojas y desde los mismos árboles se alimenta el lote y también la rotación de los cultivos para que no se agote el terreno, un año siembran aquí se deja descansar y se sigue a otro lado y cuando ese descansa va creciendo otra vez la corteza y va pasando a otro lado toda esta parte de atrás es protección para sacar para la casa los árboles de la casa, para la medicina, para ir a cazar, para coger los animales una serie de actividades que son complementarias al lote que usted tiene a la orilla de los ríos o las quebradas (Mena, 27 de julio de 2010).

Así las cosas, se puede sostener que las Comunidades Negras del Medio Atrato sustentan prácticas vernáculas que las identifican étnicamente desde el punto de vista de las estructuras de la alteridad. Su concepción del territorio y las prácticas económicas y de producción permiten establecer que los negros ostentan lógicas propias que se distinguen de los patrones culturales occidentales. No obstante, es de anotar que aún cuando se puede encontrar afinidad en las visiones de Guillermo Arcila, el padre Gonzalo de la Torre 
y Zulia Mena, se debe reconocer que hay una romantización de las prácticas culturales. Pero no es para menos, las comunidades motivadas por la defensa de su territorio tenían que dramatizar sus condiciones de vida para demostrar que en realidad ostentaban una cultura propia. Pero sus prácticas no se reducen al territorio y por ende se puede pensar que no hay un uso instrumental en el discurso de etnización, antes bien, se puede pensar en una cosmovisión, pues a juicio de Sergio Chaparro, un profesor e investigador de la Universidad Pedagógica y Tecnológica del Chocó, se puede hablar de una espiritualidad afro:

[...] al pueblo afro lo une una sola cosa, la espiritualidad, es lo único que lo une, lo coacciona. Esa espiritualidad se manifiesta en varias cosas, por ejemplo, en el rito de la ombligada; el rito de la ombligada lo que presentiza es un mito entonces cada vez que se ombliga a un neonato se está actualizando el rito y el mito entonces lo que es profundo es detrás del rito cual es el mito y ese mito hace parte de una religiosidad de un momento fundacional, de un momento de la creación y lo presentiza a través del rito, entonces ese rito a través de la ombligada es una manifestación de la espiritualidad; de la forma como la gente negra se relaciona con la naturaleza, con sus semejantes y con los espíritus, con el mas allá y con las divinidades. Entonces yo a veces lo que creo que la gente tiene en el disco duro del inconsciente del subconsciente tiene presente toda una metodología africana que la hace vidente a cada rato, la hace presente a cada rato sin reflexionar sobre lo mismo sobre ella. Por eso digo que la intelectualidad afro no ha reflexionado, no ha construido un pensamiento afro justamente de lo que hablamos de la espiritualidad que es lo único que le quedó al afro en América para sobrevivir, en Colombia para sobrevivir; la espiritualidad se manifiesta en dos momentos importantes en las comunidades: la muerte y la fiesta, son dos escenarios espirituales de máxima exposición de las concesiones espirituales arraigadas.

De este modo, las prácticas culturales de las comunidades no se reducen exclusivamente al territorio, en términos de la producción y explotación de recursos, también aluden a una cosmovisión fundada en una profunda espiritualidad. El nacimiento, las fiestas, la muerte, no son más que expresiones de una serie de prácticas que unen al pueblo negro. En palabras de Carlos Andrés Meza (2002), hay ritos para los velorios, entierros, novenarios, pero también para los síndicos, alumbrados y valsadas. En los velorios, por ejemplo

Mientras los carpinteros construyen el cajón, se encarga pan a algunas mujeres horneadoras, comida que se reparte por lo general hacia la media noche 
junto con cigarrillos, licores y confites, que circulan paulatinamente entre los allegados. En la casa del difunto debe adecuarse un volao, o techo, que amplía el espacio de la vivienda, con el fin de que las personas que lleguen a acompañar durante la noche estén protegidas de la lluvia (p. 238).

Estas y otras prácticas dejan ver la naturaleza comunitaria del pueblo negro. De manera que el argumento de la etnicidad es plausible en reivindicación de la propia cultura. Pero, no se puede quedar allí pues el territorio es precisamente el lugar donde se desenvuelve esta cultura, sobre todo, si se tienen en cuenta ritos como la ombligada - de la que se habló en el primer capítulo-. Así es que, siguiendo a Aurelino Quejada (27 de julio de 2010), líder de Consejo comunitario Mayor de la Asociación Campesina Integral del Atrato -COCOMACIA, se puede afirmar que:

[...] lo fundamental es el territorio; nosotros nos organizamos por defender el territorio porque vivíamos en un territorio y el territorio es el entorno que nos une, que nos convoca, donde nosotros podemos desarrollar nuestra cultura. Todas las Comunidades Negras hablan es de cultura, sino tenemos el territorio donde vamos a dejar nuestra cultura, entonces para nosotros del territorio se desprende lo demás porque en el territorio tenemos nosotros la propia autonomía su propio desarrollo donde nosotros podemos trazar los planes de vida, planes de etno-desarrollo, planes de educación bueno lo que queramos pero es todo el territorio.

Es entonces, que surge el problema de la identidad, pues las comunidades se ven socavadas por la cultura occidental que se impone y les imprime lógicas disímiles sobre todo a los miembros más jóvenes. En este sentido para las personas mayores, al tener arraigados los valores, es más difícil perder el entronque con su comunidad y con su territorio; pero aquellos que apenas empiezan a conocer las prácticas al chocarse con otras cosmovisiones, tal vez más atractivas (por su edad), pueden perder el interés por la comunidad. En palabras de Zulia Mena (27 de julio de 2010)

Una debilidad que tiene el pueblo negro hoy es el problema de la identidad porque usted solamente nace con ella porque sea del pueblo sino que usted la va construyendo a medida que va tomando conciencia y se va comprometiendo con esos valores colectivos porque la sociedad occidental son los valores individuales esta cultura afro e indígena es todo los derechos colectivos del pueblo que en la medida que se mantengan esos bienes colectivos usted como individuo va a subsistir usted va a garantizar los derechos de esta generación. 
Bajo estas circunstancias, la etnoeducación se plantea como el medio idóneo para resolver el problema de la transculturación y la pérdida de valores de la comunidad negra;

[...] hay mucha gente que cuando se sale del pueblito ya no retorna y si retorna ya ve raro lo que pasa allá ya no se identifica con lo que se encuentra allá; ahí está el problema pero yo aspiro que cuando se aplique a cabalidad lo de la etnoeducación en donde al niño y al adolecente le hagan entender cuál es la razón de ser de la etnoeducación y de su cultura podemos tener jóvenes comprometidos con el proceso mientras tanto hay es oportunistas que se meten allí es para sacar partido (Arcila, 27 de julio de 2010).

Por tanto, se puede cerrar este apartado afirmando que el pueblo negro del Pacífico y específicamente del Medio Atrato sí tiene una identidad étnico-territorial, en tanto que sus prácticas vernáculas se asientan sobre el territorio y se fundan en ritos como la ombligada. Por ende, es impensable la cultura afrocolombiana del Pacífico escindida de su morada, pues su espiritualidad y su cosmovisión están constituidas allí, sin embargo, aún cuando las comunidades comparten todos estos arraigos y costumbres, es preciso aclarar que la identidad no significa homogeneidad, pues compartir cierta cultura no quiere decir que todos los individuos piensen igual. Esta distinción resulta relevante desde el punto de vista del posdesarrollo debido a que, aún cuando se afirma que las comunidades tienen practicas vernáculas que deben ser respetadas, eso no quiere decir que las concepciones sobre el desarrollo o sobre la propiedad sean iguales para todos. De esta forma, será preciso revisar el marco conceptual del posdesarrollo porque presumiblemente puede aludir a un pluralismo de la homogeneidad, o dicho en otras palabras, a un reconocimiento del otro como entidad unitaria.

\section{Entre la propiedad privada y la titulación colectiva}

Teniendo en cuenta que las comunidades del Medio Atrato sustentan prácticas comunitarias que las identifican étnicamente, el asunto ahora se sitúa específicamente sobre el territorio. Ya se explicó que la lucha por el espacio tiene que ver con las cosmovisiones del pueblo negro y con el arraigo al territorio, pero queda por estudiar ahora si este arraigo se asienta sobre la concepción privada de la propiedad, característica de las sociedades liberales, o se sustenta en la propiedad colectiva propia del instrumento de titulación ideado por la Ley 70 de 1993. 
Con base en este planteamiento, habría que pensar inicialmente si las comunidades negras a pesar de sostener prácticas comunitarias, tenían lógicas individualistas en el acceso a la propiedad. Es de anotar que el hecho de que no existieran títulos -en muchos casos- no quiere decir que no existieran lógicas de apropiación individual. Al respecto, sostiene Guillermo Arcila (27 de julio de 2010) que:

[...] ancestralmente todas las familias tuvieron uno o dos lotes. Le voy a colocar este ejemplo "yo soy Esildo Pacheco Mosquera de mi mamá Mosquera y Pacheco de mi papá en este río este es el principal Baudó, en este río Baudó nació mi mamá Bartola Mosquera, pero en el río Erevere nació mi papá Leovigildo Pacheco y Leovigildo en sus andanzas salió de su cuenca del río Erevere haciendo actividades y vino a dar al Baudó y conoció a Bartola, se enamoró con Bartola, la cogió y la trasladó a Erevere; pero igual pasa, puede ser el hombre que se traslade al área donde vive la mujer no hay diferencia, dependiendo el estado valga la redundancia de estabilidad para la sostenibilidad de los hijos que va teniendo el uno se va al lugar del uno o el otro se va al lugar del otro. Pero como le muestro en el croquis la familia Pacheco Mosquera puede ser dueña de estos cinco lotes que están en cuencas diferentes, pero son ancestralidades y estos cinco lotes que usted allá tiene en cuencas diferentes son propiedad privada ancestral y estas propiedades privadas todo el mundo las respeta y las reconoce como propiedad privada.

Esta afirmación de Guillermo Arcila parece controvertir la cosmovisión de las Comunidades Negras del Medio Atrato, más aún si se tiene en cuenta que estudiosos sobre el tema, como Sandra Patricia Martínez (2010), afirman que estas comunidades tienen preferencia por las prácticas individuales y familiares de apropiación territorial y por la propiedad privada y la "defensa de lo propio". Al respecto, señala la doctoranda en Antropología de la Universidad Iberoamericana de México, que un poblador de la comunidad del Alto Andágueda después de un breve recuento de la gesta librada por las negritudes en busca del reconocimiento de los derechos étnicos preguntó "¿Y por qué si en otras zonas del país la propiedad individual en esta comunidad tiene que ser colectiva?" (p. 28), ciertamente la pregunta deja en evidencia la postura de un campesino que ha estado marginado del proceso de titulación colectiva, pero también deja de manifiesto la ambigüedad que hay en torno a la propiedad. De momento, se puede decir que el título colectivo engloba la propiedad privada

[...] qué hizo la Ley 70 con estas propiedades privadas [...] las englobo a un solo lote general y estos espacios que usted ve todos eran lo que anteriormente 
se llama Baldíos de la nación, eran baldíos en el contexto general los lotes eran propiedad privada por no tener un título el Estado los asimilaba también a baldío nacional pero para la gente que es su propiedad privada de los Pacheco Mosquera porque ese es su lote que les dejó su abuelo, su papá o uno se lo compró a otra familia que también se daba la compra-venta así a través de pólizas, constitución de pólizas y se respetaban. Entonces a la Ley 70 colita un título colectivo todos estos lotes de los Pacheco Mosquera quedan dentro del título colectivo, pero aquí entre el título colectivo la comunidad sigue respetando esto como propiedad privada (Pacheco, 29 de julio de 2010).

Pero sí en el imaginario de las comunidades estaba la defensa de la propiedad privada, habría que preguntarse ¿por qué se decidió titular colectivamente?, al respecto anota Aurelino Quejada (27 de julio de 2010) que:

[...] empezamos a solicitar el titulo, título individual, pero un estudioso a nosotros nos hizo un diagnóstico y dijo - ustedes están tratando de titular ochenta mil hectáreas, ahí hay siete mil quinientas familias individualmente ¿cuántos títulos son? cuándo ustedes titulen si ustedes inician en el 89 se gastan 50 años para el último título individual, o sea el último que espera ese título ya no lo reciben los hijos sino los nietos - eso es muy lento piensen en otra propuesta porque esa no les va a funcionar porque mientras ustedes vivan van a pelear cuando ya estén en cola listos para titular dan una pelea interna por donde iniciar, los de abajo tienen por debajo para arrancar primero y los de arriba por arriba y los del medio que y es una pelea que piensen eso - entonces ya empezamos a iniciar eso no nos sirve así hablemos de título colectivo por eso no funcionaba entonces seguimos nosotros el proceso organizativo.

Bajo estas circunstancias es posible afirmar que en la conciencia del pueblo negro a pesar de las prácticas culturales comunitarias, existía una conciencia individualista de la propiedad. Pero no es una conciencia individualista, en el sentido estrictamente liberal, pues de acuerdo con un trabajo realizado por la ACIA y la Red de Solidaridad Social:

[...] para cada comunidad los bosques, las minas, las ciénagas y el río son de propiedad colectiva, mientras que la casa de habitación, los instrumentos de trabajo y el terreno de cultivo son de propiedad familiar, y las cosas de uso personal, de propiedad individual (COCOMACIA, 2002, p. 63).

Esto quiere decir, entonces, que conviven dos formas de apropiación: una privada y una colectiva. Pero lo más interesante no es la convivencia de estas dos formas en el imaginario del pueblo negro, lo atractivo es el sentido que se le da a la propiedad privada en tanto que para la propiedad ancestral: 
[...] resulta y pasa que las Comunidades Negras ancestrales en este país han poseído el territorio y se han sentido propietarios en el alma, yo soy hija de campesina lo que pasa es que yo llegué antecitos que otros campesinos aquí al poblado pero mi territorio está aquí en el Rio Kiko y nadie me lo quita que es el territorio de mis abuelos de mis bisabuelos, mi territorio está en el Rio Capa porque por derecho propio nadie puede decir que yo no soy heredera digna de mi familia o alguien se puede meter porque yo en 20 o en 50 años no vaya a sembrarlo entonces el tema aquí, la visión no es muy romántica, la visión recoge el concepto de propiedad que tenemos las comunidades negras en la cabeza éramos los dueños y creíamos que éramos los dueños más allá del reconocimiento de la propiedad.

Sin duda la concepción de la propiedad en el Pacífico denota cierta particularidad pues espacios como el bosque son concebidos como comunitarios y otros espacios como la casa son concebidos como privados. Esta última concepción de la propiedad, no es igual a la que se da en las sociedades liberales. Una de las particularidades que se presenta es que por ser de arraigo ancestral, todo lo que posee la familia le pertenece al individuo, independiente de que la use o la habite. Esto connota diferencias marcadas, teniendo en cuenta que las comunidades, hasta la Ley 70 de 1993, no contaban con títulos. En otras palabras, la tradición oral es tan fuerte que sin necesidad de un reconocimiento legal, se respetan los espacios privados. Para Idalmy Minota (28 de julio de 2010) esta forma de pertenencia alude a un estilo de propiedad por troncos familiares y por tradición ancestral. Pero, teniendo en cuenta estas dos formas de apropiación, queda por preguntarse por qué los afrodescendientes no titularon antes de la Ley 70 de 1993, o incluso antes de la Ley 2 de 1959. Al respecto Guillermo Arcila (27 de julio de 2010) sostiene que

[...] nunca nos preocupó titular la tierra porque siempre tuvimos en mente retornar a nuestra África por eso se formaron los palenques, los esclavos que lograban escaparse del esclavista y se alzaban en las grandes montañas y no hacían sino formar un palenque porque a ver que dicen los historiadores la topografía la vegetación nuestra la ideografía nuestra es muy parecida a la de África, los grandes ríos mire usted consigue que el Atrato que es uno de los ríos más caudalosos del mundo, consigue el río San Juan uno de los ríos más caudalosos del mundo son ríos tan pequeñitos por ejemplo el rio San Juan tiene unos trescientos cincuenta kilómetros y suelta millones de litros de agua al mar si el San Juan fuera como el Orinoco la gente se va para otro lado; es que es mucha agua la que le cae el Rio Atrato es una maravilla inmensamente grande, el rio Magdalena; mire todos los negros que están en la zona del Ca- 
ribe cuando se encontraron con el Magdalena se imaginaban que se estaban encontrándose con sus grandes ríos allá en áfrica esa selva, esa vegetación, esa lluviosidad todo eso muy parecido entonces ellos, muchos de ellos creyeron que habían llegado, resulta que ellos venían de lejos, ellos nunca supieron que tan lejos estaban por eso no les interesaba titular la tierra aquí donde estaban pero se quedaron tantos años allí que nosotros sus descendientes lo sentimos como nuestro porque es que ancestralmente hemos estado allí.

De acuerdo con este argumento el pueblo negro de la cuenca del Pacífico no decidió titular porque siempre se sintió desarraigado de su África natal y por ende siempre tuvo en mente regresar. Sin embargo, de lo planteado por Arcila (27 de julio de 2010) queda una ambigüedad; pues no se entiende si no titularon porque se sintieron en "casa" dadas las características geográficas del Pacífico, o debido a que pensaban regresar a su continente. Al respecto se agrega que:

[...] aunque las Comunidades Negras están diseminadas en todo el país es muy importante decir que en el sector de la Costa Pacífica se encuentra la mayor población negra del país y tenía una característica muy especial la mayoría de la tierra no estaba titulada, yo pienso que básicamente porque en el proceso de la llegada de los negros a América y principalmente a Colombia en eso siempre tuvo en mente retornar, retornar a su África y esto se fue quedando tan inmerso en la gente que lo que menos le interesaba era titular la tierra porque para que yo me pongo a titular la tierra si yo tengo como perspectiva irme, irme a donde vine, entonces la tierra siempre se quedó con posesión física pero no legalizada o sea muy poca gente de Comunidades Negras se interesó por tener un título de propiedad de la tierra donde trabajaba o donde ancestralmente estaba asentado.

Este punto de vista es radicalmente cuestionado por Idalmy Minota (28 de julio de 2010) con base en un argumento generacional bastante plausible

[...] no le creó para cual África vamos a regresar [...] digamos que eso es cierto con la primera generación que llegó, pa donde iba la segunda y la tercera y la cuarta y el resto de las generaciones, pa cual África voy yo, a mi me van a decir hoy que yo no quería titular porque quiero regresarme a África.

Esta concepción totalmente en contravía con una idea nostálgica de desarraigo del pueblo negro, asienta el problema en la falta de reconocimiento del Estado y no en la voluntad de los afrodescendientes

[...] como va a ser tan romántico para decir que nosotros fuimos los que no quisimos titular, que nosotros fuimos los que no quisimos cuando ni siquiera 
podíamos ejercer el derecho al voto, cuando no teníamos alma para los españoles, para la iglesia los negros éramos un poco menos que animales, entonces como va a poner en cabeza nuestra la responsabilidad de no haber legalizado nuestra propiedad en qué cabeza cabe que un Cimarrón, porque los que nos apropiamos los ancestros que se apropiaron de estos territorios fueron cimarrones [...] si el Estado Colombiano nunca me reconoció el derecho a ser siquiera persona y el primer derecho en cualquier derecho civil es el derecho a ser persona que me van a reconocer esa propiedad para decir que yo renuncia porque quería regresar a África (Minota, 28 de julio de 2010).

De este modo se pueden indicar dos posiciones con respecto al problema de la titulación de las tierras en la cuenca del pacífico; de un lado la que piensa que fue por voluntad de los negros; y de otro lado la que supone que fue culpa del Estado. Lo cierto es que desde cualquiera de los dos puntos de vista el territorio cumple una función esencial dentro del imaginario de las comunidades negras. Como lo reconoce la misma Idalmi Minota (28 de julio de 2010):

[...] acá el tema es diferente hemos nacido y hemos vivido por siglos en este territorio no es solamente la vivencia mía sino todo ese legado cultural y espiritual del que yo me alimento, yo tengo 46 años yo no tengo hoy solamente mis 46 años en este territorio yo tengo lo que tienen mis abuelos, mis bisabuelos, el primer ancestro que llego entonces, el apego a este territorio se extiende al apego que cualquiera tuviera por un pedazo de tierra que compró, donde vivimos tenemos enterrado el ombligo yo no lo tengo escondido, yo no le soportó que usted haga lo que le dé la gana porque yo allá tengo enterrado el ombligo, yo tengo enterrado el ombligo allá, allá esta mi ombligo y eso significa demasiado [...] son elementos espirituales muy fuertes como para que no se tengan en cuenta frente a qué es lo que las Comunidades Negras queremos aquí; Comunidad Negra sin territorio no existe.

En consecuencia, se debe reconocer en conformidad con las prácticas vernáculas y la cosmovisión del pueblo negro, que el territorio es central en la cultura, independiente de las formas de apropiación. Quiere decir que aún cuando perviven formas de apropiación individual con formas de apropiación colectiva el apego al territorio sigue siendo el mismo, aunque parezcan existir contradicciones entre lógicas liberales y lógicas étnicas. Lo que sí parece confuso es el manejo que se le da a la titulación producto de la Ley 70 de 1993, pues ésta reconoce la propiedad colectiva y desconoce la propiedad privada. Sin embargo, como se planteó antes, el título engloba la propiedad por troncos familiares. 
Un aspecto que resulta de suma importancia es el papel que debe jugar la educación dentro de todo este proceso, pues, como lo señalaba Sandra Patricia Martínez (2010), las comunidades sienten que esta forma de apropiación violenta sus posesiones. Por esta razón, indica Guillermo Arcila (27 de julio de 2010) se le debe explicar a la comunidad las implicaciones de la titulación colectiva:

[...] la Ley 70 a partir del 93 cuando ya la gente se pide la reivindicación de sus tierras entonces se plantean otras cosas y es la tierra como propiedad colectiva no individual y quienes tenían hasta esa fecha títulos particulares siguen hoy teniendo sus títulos particulares pero la ley en cierta medida tuvo muy poca difusión previa y hubo personas que tenían propiedades que no se enteraron del proceso de comunidades y sus tierras quedaron inmersas dentro del título colectivo, ese es un conflicto que cualquier día explota porque hay personas que no admiten que sus tierras se las maneje el colectivo porque ellos argumentan tener unos títulos de propiedad que en la mayoría no son válidos, conozco muchos casos que son declaraciones extra-proceso en donde necesitaban certificar que yo estaba sentado aquí y aquí se hacía eso y yo creía que eso era una escritura que me daba un derecho a título y no es cierto. En muchos casos no es cierto y en otros casos sí; en donde si era cierto tenían sus títulos de verdad pero con la poca difusión la gente no se enteró o no le dio importancia a eso, no manifestó no querer pertenecer al título colectivo y quedaron inmersos y hoy hay ese conflicto entre los procesos organizativos y las personas que individualmente tenían un predio, igualmente se da que la tendencia ancestral hay personas que no admiten que el colectivo se los administre porque la verdad eso le hace falta mucha capacitación, se ha dado bastante capacitación pero hace falta más, hace falta que se le llegue a la gente con propuestas muy coherentes, muy serias y muy ciertas y que la gente entienda el proceso de colectivización.

Esto deja sobre la mesa el conflicto por el territorio del que se habló en el primer capítulo y que para Carlos Agudelo denota el escaso o nulo interés que se le da a las formas de apropiación individual, independiente de que sean negros, chilapos, paisas o indígenas. Por esta razón respecto a las otras etnias es preciso delimitar los territorios y espacios comunes; y referente al pueblo afro es preciso llevar a cabo un proceso de concienciación del proceso de colectivización.

Bajo estas circunstancias es importante anotar que estos procesos de capacitación comunitaria los vienen adelantando en el Medio Atrato consejos 
como COCOMACIA y organizaciones como el Foro Interétnico Solidaridad Chocó. Así que la tarea de llevar la Ley 70 de 1993 a las organizaciones de base y a los campesinos en general ya se está haciendo. Cabe anotar, como se verá en el siguiente apartado que la educación que se imparte no debe apelar a estrategias colonizadoras en el sentido de imponer verdades; por el contrario, debe reconciliar las cosmovisiones con el sentido de la ley. Esto queda claro si se tiene en cuenta que los pueblos negros de la Cuenca del Pacífico, aunque pertenecen al mismo grupo étnico no tienen las mismas concepciones sobre lo bueno.

\section{Visiones encontradas sobre el desarrollo}

Arturo Escobar (2005b) sostiene que una era del posdesarollo debe reconocer la importancia de los movimientos sociales y de las movilizaciones de base, tomando como punto de partida la revaloración de las culturas vernáculas y la necesidad de depender menos de los conocimientos de expertos y más de los intentos de la gente común por construir mundos más humanos (pp. 19-20). En estos términos es posible asumir dos interpretaciones; de un lado que el autor colombiano propende por un reconocimiento de los movimientos desde el punto de vista de las "estructuras de alteridad" con el fin de ser visto como un otro en condiciones de autonomía y con poder de interlocución; por otro lado que aún cuando se le otorga un reconocimiento a los movimientos sociales éstos hacia su interior también sustentan visiones diferenciales respecto a las concepciones sobre lo bueno. En estos términos podemos dilucidar un posdesarrollo reivindicativo y homogéneo en el nivel de los movimientos sociales y un posdesarrollo reivindicativo y pluralista. No se debe olvidar que las comunidades al otorgarles autonomía deben tener la facultad de deliberar hacia su interior; pues de lo contrario se incurriría en los mismos problemas del desarrollo en el sentido de la modernización, solo que el rol desempeñado por los expertos pasa a ser representado por los líderes o representantes.

Lo anterior lleva a señalar que la reivindicación de los derechos étnicos de las comunidades negras no supone una homogeneidad en el pensamiento del pueblo negro. El hecho que se comparta cierta tradición, ciertos valores, ciertos ritos y hasta un territorio, no quiere decir que todos los miembros de una comunidad piensen igual. Por esta razón el siguiente apartado en aras de defender un posdesarrollo pluralista y reivindicativo, presentará las 
diferentes visiones que sobre el desarrollo sustentan actores involucrados en el proceso organizativo de las comunidades negras.

De este modo, una de las visiones más extendidas dentro de la literatura del posdesarrollo es la que aboga por dejar a las comunidades que sean como son; es decir, que contrario a los mecanismos de implementación de lógicas foráneas se potencie la propia cultura y se desarrollen prácticas en conformidad con las lógicas consuetudinarias. Al respecto sostiene Aurelino Quejada (27 de julio de 2010) que:

Los Concejos Comunitarios viven de la subsistencia del territorio: hay Consejos comunitarios que son netamente pesqueros y viven de la pesca y viven bien, hay Consejos comunitarios que son mineros y vienen de la minería, hay otros que son agricultores porque eso es lo bueno de la variedad eso es lo interesante, no todos los consejos viven de lo mismo, hay unos que son agricultores y mineros, hay unos que son agricultores y madereros, hay unos que son agricultores y pescadores y entonces siempre intercambian las actividades y eso es muy enriquecedor porque uno viven de una cosa, otro vive de la otra, hay veces que el agricultor le vende el plátano al minero y así por el estilo, le vende el plátano al maderero y así o sea que es chévere porque se hacen varias actividades y de eso la gente sobrevive por eso es la importancia de defender el territorio y por esa es la importancia de que la gente viva en su territorio y la importancia de que nos respeten a nosotros nuestro territorio que nos dejen vivir allá

Dicho esto es presumible pensar que el desarrollo debe estar orientado a potenciar las prácticas vernáculas de los consejos, de tal forma que si su economía es extractiva, ésta no se vea alterada por lógicas de acumulación o por intereses disímiles como por ejemplo la implantación de lógicas mineras en pueblos agricultores. Sin embargo es preciso anotar que bajo esta lógica se defiende la idea de mantener a las comunidades en sus prácticas ancestrales y aislarlas de la técnica, de tal forma que su tradición y su cultura no se vean vulneradas. Al respecto el padre Gonzalo de la Torre (30 de julio de 2010) sostiene que:

[...] el campesino tampoco nunca ha estado tan románticamente aislado una cosa es vivir una necesidad y responder a ella comunitariamente no tener posibilidades de incorporar la técnica del mundo entonces eso mismo que va provocando una marginación matemáticamente porque el campesino siempre va a ser víctima del que tiene más técnica al no tener asimilada ningún tipo de técnica en su proceso humano siempre va a estar en desventaja, 
entonces la carne de él o sea nunca va a tener excedentes de producción, ni excedentes vendibles, ni excedentes comerciales porque nunca tiene la técnica para conservar esos excedentes nunca tiene un sitio para que la rata no se le coma el arroz, no se le coma el maíz entonces tiene que quedarse con lo indispensable para cada día, es decir, en esa comida van a estar siempre en desventaja y aparentemente es romántico pero a la hora de la verdad es su muerte ¿Por qué? porque termina siempre incorporándose a la ciudad, es la visión de que un campesino no necesite la nevera no necesite tal no porque él lo que hace es buscar equivalentes de eso y esos equivalentes siempre van a estar en desventaja, es decir, uno tiene como pensar de que la técnica es también el derecho y de que la técnica nunca engaña a los comunitarios la técnica al contrario les amplia el horizonte a los comunitarios porque si yo he visto que el campesino la única técnica que tiene para conservar carnes, por ejemplo, cuando no tiene la técnica del hielo o la técnica de la luz eléctrica para una nevera, la única es salar, salar el pescado que le sobra, salar la carne que le sobra con el agravante que eso se le convierte después en enfermedad porque el exceso de sal le sube la presión al subirle la presión mueren tantos y tantos; este es el sitio donde más muere gente de presión.

Esta concepción armónica entre la ancestralidad y la técnica supone un problema, pues el posdesarrollo establece que se deben revalorar las prácticas vernáculas y por ende se deben sacralizar las tradiciones y los valores propios de la cultura ancestral. Así que es preciso preguntar ¿Cómo implementar la tecnificación sin modificar la cultura? Es ilustrativo el planteamiento del Padre Gonzalo de la Torre (2010), pues lo que deja en evidencia es que no hay un viro cultural en la medida que las comunidades utilizan técnicas arcaicas para lograr los mismos propósitos. En este sentido la técnica no transforma las prácticas culturales sino que las vuelve más eficientes.

$\mathrm{Al}$ respecto Idalmi Minota (28 de julio de 2010) señala que esta supravaloración de las prácticas vernáculas puede tener en el fondo un propósito nefasto al pretender mantener en la miseria al pueblo negro. En otras palabras, aunque las comunidades tienen prácticas productivas ancestrales abogar por reproducir estas prácticas de subsistencia sin un fortalecimiento de la técnica es perpetuar los sistemas tradicionales de exclusión que han mantenido en la marginalidad a las comunidades del Pacífico. En sus palabras:

Las Comunidades Negras también quieren sus neveras porque no es lo mismo no tener una nevera donde poder conservar todas ese alimento, que tener que comprar al menudo todo el tiempo porque se te daña, o sea son cosas que en mi opinión no tienen que ver con la realidad de lo que es una 
apropiación cultural de un territorio, que es la base del reconocimiento es la relación cultural con el territorio que subiste y porque subsiste porque hay unas prácticas tradicionales de producción que son amigables con el entorno pero son unas prácticas tradicionales que vienen desde hace siglos, desde los primeros cimarrones que se fueron apropiando del territorio, miremos hoy la esencia de estas prácticas que han sido amigables con el entorno, como las podemos perpetuar pero también como a esa práctica tradicional producida le introducimos otros alimentos que nos permitan tener mejores excedentes en la producción pero que o sea nos vamos a quedar simplemente con el pan coger y el mínimo y jugándole al mínimo en la producción del territorio nuestro, entonces eso es tanto como condenar a la miseria y a la pobreza a la gente nuestra y yo no le puedo hacer eso, a esa visión no le podría llegar, a esa no se le puede jugar a esa si le siguen jugando las ONG y sus aliados que con ese discurso siguen pidiendo la limosna para ejecutarlos ellos y mantenerlos en las mismas condiciones.

Según esta interpretación el discurso en defensa de la ancestralidad puede llegar a tener intereses instrumentales al pretender reproducir la miseria sobre la base de la conservación de las prácticas vernáculas. Lo más grave del asunto es que se acusa directamente a las ONG de reproducir la pobreza sobre la base de unos recursos que se quedan en la mediación para el desarrollo sin que las comunidades vean avances significativos en su calidad de vida. En estas condiciones se debe decir que el posdesarrollo al darles autonomía a los movimientos y otorgarle validez a los conocimientos de la gente en contra de los conocimientos de los expertos, puede terminar cayendo en los intereses burocratizados de representantes o líderes, que bajo discursos románticos de la ancestralidad del pueblo negro pueden captar recursos perpetuando la pobreza de su comunidad.

Esto lleva a Idalmy Minota a sostener que la dependencia de los recursos de las ONG extienden la imagen limosnera del pueblo negro; algo que sin duda debe ser erradicado en función de una visión en la que las comunidades pongan a trabajar su tierra sin visiones idílicas de perpetuación de la miseria. Para Ulrich Kollwitz (29 de julio de 2010) el problema radica en la dependencia hacia fuera de las organizaciones comunitarias:

[...] la dificultad que yo veo en las organizaciones, más bien, es que no han logrado crear proyectos productivos que les permitan una entrada y les garantice una autonomía, sino que cada vez más están dependiendo de ayuda financiera de afuera eso es algo que nos preocupa muchísimo, yo ya les estaba 
haciendo la reflexión hace más de veinte años cuando les estaba acompañando en las primeras administraciones yo recuerdo una vez que esto fue yo creo que en el 88-89 al fin del año yo me senté con ellos porque la contabilidad fue todavía muy sencilla con un cuaderno entrada, salida, saldo y yo les dije vea este año han entrado pues tantos recursos, han salido tantos pero de las entradas miremos de donde han venido, ya desde el inicio había la idea de que algo tenía que aportarnos a los campesinos los socios de la ACIA en ese momento habían fijado una cuota trimestral de cien pesos mensuales pero cada tres meses iba a cobrar y con eso y otros pequeños aportes en aquel momento estaban cubriendo el $4 \%$ de sus gastos entonces ya les dije va a ser muy importante aumentar ese porcentaje poco a poco ojala que dentro de dos o tres años ya ustedes puedan cubrir el $10 \%$ de recursos propios dentro de unos diez años el 20 o el $25 \%$ y así poco a poco dejar de depender tanto de lo que viene de afuera, cuando yo volví a finales de los 90 y estaba observando todo el manejo de proyectos me di cuenta que lo que pasó fue lo contrario, pues yo no tengo ya acceso a esta cifra pero me atrevo a decir que en este momento uno pregunta bueno de todos los recursos que ustedes manejan cuantos vienen de afuera y cuantos vienen de aquí mismo de ustedes porque ya ni siquiera son el $4 \%$ la dependencia es demasiado grande que todo viene de afuera.

Bajo estas circunstancias lo problemático no solo es el discurso de romantización de las prácticas tradicionales para pauperizar el pueblo negro; también se puede decir que el desarrollo sin potenciar una autonomía real de las comunidades puede resultar catastrófico por la dependencia que genera. En estos términos aun cuando las comunidades organizadas en consejos como COCOMACIA participan en "condiciones de igualdad" dentro de los procesos de desarrollo que diferentes ONG llevan a cabo en la región; lo que preocupa, siguiendo a Kollwitz (29 de julio de 2010) es que cada vez son más dependientes de los recursos y son menos autónomos en el manejo de su territorio. Incluso se puede afirmar que esta dependencia tiene una forma manifiesta en la "proyectitis":

[...] cuando vienen con una oferta para seis meses o hasta para tres meses que proyección puede tener eso, eso son limosnas ayuditas algo una plata que se ofrece para montar algo rapidito pero no tiene proyección y eso siguen llamando proyecto y esos son los proyectos que digo hasta que al final hacen más daño que bien porque le quitan tiempo a los líderes eso se puede observar ya mucho en los últimos años que los líderes que antes tenían mucho tiempo para visitar las comunidades, para sentarse y analizar la situación y elaborar propuestas como defender los derechos de las comunidades ahora están abarcados por sentarse a llenar papales, informes, rendir cuentas, atender una 
reunión con tal agencia, hoy otra con tal agencia, mañana los convocan a un taller por allá, a una reunión por otro lado y en eso están funcionando y eso ha causado inclusive la imagen de muchos en el campo decir ese es su líder, se pasea por ahí por allá y aquí ya no lo vemos, ¿Qué están haciendo con nosotros? eso viene de esa proyectitis porque todas estas agencias normalmente quedan hasta el concepto ustedes como organizaciones se tienen que poner de acuerdo, tienen que trabajar unidos pero ellos mismos como agencias nunca son capaces de ponerse de acuerdo en un concepto único, un formato único, hacer un proyecto como rendir las cuentas; cada agencia tiene su esquema diferente, entonces para cualquier platica que viene tienen que recibir una formación diferente como llenar los formularios, como llevar adelante la administración y eso le implica todo el tiempo no son capaces de decir aquí una realidad porque es una sola y frente a esta realidad muchas necesidades, hay muchas agencias que pueden cubrir una cosa, otros pueden cubrir otras cosas, pero hagamos un proyecto de eso con una misma justificación, con una planeación donde después se hace un solo informe, se lleva una sola administración, una sola cuenta y se dan de vez en cuando reuniones con todos, esto sería algo muy eficaz pero eso las agencias no quieren eso, no lo quieren y por eso la gente está en función a las agencias no las agencias en función a las organizaciones.

En este sentido se puede decir que la dependencia de los recursos de fuera termina por separar a las comunidades de sus líderes, produciendo con ello el problema de la burocratización de la que se hablará en el siguiente apartado. Por ahora puede afirmar que con todos los problemas de los que se habló una de las visiones más extendidas en el Medio Atrato sobre el desarrollo es la que se contempla a través de los recursos de las ONG. Pero éste no es el único discurso que se plantea; Idalmi Minota (28 de julio de 2010) hablará de un modelo de Entidades Territoriales Autónomas -ETAS, sobre la base de una crítica al "modelo limosnero" de las ONG.

[...] el tema de las ONG no es simplemente que haga una intermediación entre la limosna que mandan los otros y nosotros, el tema es la limosna, yo no me puedo reducir a limosnera ni en términos individuales ni en términos colectivos, si yo soy dueña de este territorio que tiene una riqueza yo tengo derecho a desarrollarme con mis riquezas y no esperando limosna, hay un tema de dignidad así de sencillo, el tema es de dignidad como así que nos vamos a convertir las Comunidades Negras en el limosneros eternos [...] aquí hay dos visiones unos que consideran que el problema es que ir a denunciar a nivel internacional y a poner la queja para traer la limosna [...] nosotros que consideramos que dentro del Estado colombiano tenemos unos derechos idea- 
les y al Estado colombiano es al que tenemos que presionar desde diferente puntos desde diferentes ámbitos para que se siente con nosotros a concertar el reconocimiento y el ejercicio de esos derechos.

El segundo modelo de desarrollo propuesto por las comunidades se refiere a las EATS, que se fundan sobre el supuesto de que no se deben romantizar las tradiciones y las necesidades del pueblo negro buscando atraer los recursos de las agencias internacionales; sino que se debe presionar al Estado para reclamar los derechos que como colombianos les corresponde a las comunidades negras del Pacífico. En este sentido, la propuesta de las ETAS es vista por Idalmy Minota (28 de julio de 2010) como:

[...] los territorios de colectivos de Comunidades Negras tienen las mismas características jurídicas y las mismas restricciones que los resguardos indígenas, son imprescriptibles, inalienables e inembargables las tres "I", el asunto es que siendo como son las tres "I" tienen toda la vocación de convertirse en entidades territoriales como el acuerdo de los indígenas, hay una discusión de interpretación que nos ha salvado, yo soy de la interpretación restrictiva y es que los entes que pueden ser las unidades territoriales como tal las escribió taxativamente la constitución nacional y dijo que las etnias podrían constituir a despensas dentro de lo taxativo de entidades territoriales no incluyen a las Comunidades Negras como yo soy casada en esa concesión restrictiva opino que para las Comunidades Negras puedan acceder a tener la vocación de convertirse, no que serán inmediatamente, sino que será un procedimiento como se dice en entidades territoriales autónomas, se requiere de una reforma constitucional; hasta ahí vamos en esa discusión jurídica, que es lo que permite convertirse en entidades territoriales, una que puede ser objeto de asignaciones presupuestales dentro del sistema de participación normal del Estado Colombiano [...] si somos entidades territoriales vamos a tener una competencia más importante para definir nuestros propios planes de desarrollo.

$\mathrm{Al}$ respecto se debe anotar que la Ley 70 de 1993 solo reglamentó el capítulo correspondiente a la titulación colectiva y dejó de lado la reglamentación de otros capítulos como el VII de Planeación y fomento del desarrollo económico y social. Es así que la propuesta de Idalmy aboga por un reconocimiento de los derechos económicos y sociales. Tal parece que la responsabilidad del Estado con las comunidades negras del Pacífico terminó con la titulación colectiva, pues el fomento de las actividades productivas y la provisión de derechos es muy pobre en esta región. Además, el título colectivo al ser inembargable no permite a las comunidades pedir préstamos para proyectos productivos. 
De manera que la Ley 70 de 1993 termina siendo incompleta, al garantizar un espacio, pero sin condiciones de desarrollo para las comunidades. Bajo estas circunstancias, Esildo Pacheco (29 de julio de 2010) profundiza en esta Propuesta y habla de las Entidades Territoriales Afrocolombianas -ETAC

[...] yo pienso que el mal se ataca de raíz para poder ir posesionando las otras cosas, si yo tengo la seguridad de un territorio donde hay una legislación una norma que me tiene que dar la sostenibilidad del territorio entonces yo desde ahí creo que puedo hacer lo que quiera: empresas, negocios, bueno lo que se me venga en gana porque tengo una seguridad, entonces yo soy de los que comparte la idea que los territorios étnicos y Comunidades Negras se tienen que convertir en un organismo, un ente territorial con una asignación propia y directa del Estado, es mas así lo contempla la Constitución Política Colombiana entonces cada grupo étnico debe ser responsable de la administración y la ejecución de su territorio, de sus recursos naturales, si este Consejo comunitario del Baudó que tiene tres municipios si los recursos les llegan en situado nacional directo al Consejo comunitario y que los recursos ya lo administran no son tres alcaldes cada uno desde su alcaldía sino que los que los están administrando son treinta y siete juntas directivas son trescientas setenta personas, aquí hay un mayor control es muy difícil comprar a trescientas setenta personas frente a la compra de tres es mi visión es más fácil yo manipulo a estos tres alcaldes, uno por uno, para que se despilfarren los recursos, a manipular treinta y siete personas que entre otras cosas tienen una veeduría.

No hay duda que la propuesta es ambiciosa y tiene correspondencia con la reivindicación de los derechos étnico-territoriales de las comunidades negras durante la década de los noventa. Sobre todo resulta atractiva la idea del control político en el manejo de recursos; pues como se mostrará más adelante la estructura de los consejos mayores y los consejos locales establece una dinámica diferente en términos de jerarquías y poder. Sin embargo, no todos creen que estas entidades territoriales sean el modelo ideal de desarrollo para los consejos, a juicio de Guillermo Arcila (27de julio de 2010):

[...] ya los indígenas lo lograron desde el tiempo de la colonia son entes territoriales y ellos manejan recursos del Estado para el desarrollo de sus comunidades pero uno ve cada día las comunidades indígenas inclusive mas jodidas que nosotros y ellos si manejan algunos recursos uno no sabe cómo y a mí me preocupa sobre manera cuando los negros estemos manejando los recursos, mire los alcaldes los muchos de nuestros alcaldes en todo el Pacífico terminan los períodos de las alcaldías y se van a pasar dos o tres períodos a la cárcel, 
entonces usted se imagina cuando nosotros como entes territoriales estemos manejando los recursos, pero eso no es para decir que no podemos manejar nuestros recursos alguien tiene que salir y hacer las cosas bien y demostrar que sí podemos, porque todos no somos corruptos pero la clase politiquera de este país y de este departamento cuando seamos ente territorial todos los negros que son dueños del proceso y van a querer estar administrando los recursos para que sirva a penas para una persona y no para la comunidad en general eso me preocupa, pero imperceptiblemente allá tenemos que llegar, cuando no lo sé y sería bueno que llegáramos.

Es preciso afirmar que uno de los riesgos que corre el proceso organizativo de las comunidades negras en el Medio Atrato al lograr su consolidación como entidad territorial es la corrupción. De manera que contrario a lo planteado por Esildo Pacheco esta vía en lugar de prevenir la corrupción la potencia. Se puede decir que las dos posiciones son parcialmente ciertas; pues de un lado una entidad territorial con la estructura de un consejo comunitario asumiría un mayor control político sobre los recursos; y por otro, una entidad territorial captaría mayor atención del sector político de la región y por ende habrían más riesgos de que los consejos se convirtieran en feudos de la clase política en desmedro de las propias comunidades.

Sin darse un consenso sobre esta visión del desarrollo se puede plantear un tercer modelo asumido sobre todo por miembros profesionales de la comunidad; según el cual los consejos deberían organizarse con la estructura de una empresa:

[...] nosotros aquí no podemos vivir de subsistencia teóricamente local, nosotros tenemos que crear nuestras propias empresas y que eso genere una fuente de ingresos que den más fortaleza para nuestros campesinos; es que nosotros tenemos aquí una fortaleza grandísima que es la producción de la tierras en sus grandes extensiones, tener una habilidad de productor inmenso una riqueza grandísima pero no tenemos la forma organizativa de una empresa o nos falta la ayuda estatal porque aquí llegan a veces muchos proyectos y se quedan en la mano de los dirigentes (Pacheco, D. 28 de julio de 2010).

Sin embargo, esta visión puede transformar radicalmente la cultura de las comunidades afrodescendientes, dado que se saltaría de una economía extractiva a una economía de acumulación. Pero al respecto el mismo Diógenes Pacheco (28 de julio de 2010) agrega que "estamos en el mundo de la globalización y el aspecto es de ir avanzando y esas cuestiones tradicionales 
ya tuvieron su época ya uno tiene que irse modernizando y tener acceso a todos los servicios que presta el Estado". Más aún, como lo agrega Helcias Ayala (26 de julio de 2010) la estructura de los Consejos se debe cambiar profundamente, asumiendo una estructura gerencial

[...] se necesitan estructuras de gerencia, así como funcionan entidades corporativas, es decir, unas juntas que no tengan roles administrativos sino unas juntas que tengan el rol de direccionamiento político y de co-administración así como funciona por ejemplo el Instituto de Investigaciones Ambientales del Pacífico; este instituto tiene una junta directiva, convergen aquí los socios a la junta directiva son los que le pasan políticas al director, cierto, le aprueban el plan de acción, le aprueban el presupuesto, le aprueban el plan de estrategia, le aprueban el plan de investigación y el director tiene que presentar un informe como debe ser, de su gestión, de cómo esta mi gestión en el instituto pero tenemos una auditoría externa, tenemos un revisor fiscal así deberían funcionar las juntas de los Consejos comunitarios, pero todos ellos tienen un presidente, tienen fiscal, secretario, tesorero son buena parte de las decisiones cierto, ellos mismos ejecutan, administran ellos mismos y no tienen nadie que les haga una veeduría externa, entonces el representante legal o el presidente es un miembro de la comunidad que vive por allá, para poder asumir la gestión adecuada, para poder enrutar los Consejos comunitarios por donde debe ser tiene que abandonar sus actividades cotidianas y despegarse de la familia o trasladarse con la familia a un centro de operación a una localidad donde le permita operar adecuadamente y que normalmente lo que va a ocurrir es en los cascos urbanos, porque en los cascos urbanos hay internet, hay comunicación, hay posibilidades de transportarse a Quibdó a Bogotá o a donde sea para poder buscar los recursos para poder apoyar la región, para poder informarse de lo que está pasando, entonces por eso digo que se necesita la estructura de gerencia donde el representante legal no tenga que ser una persona de la comunidad o mejor dicho miembro de la comunidad sino alguien, un profesional por ejemplo, al cual se le tengan un nivel de confianza, un trabajador social o administrador de empresas de ese entorno comunitario que uno le encargue, vea maestro aquí hay este presupuesto, este plan de acción de Consejos comunitarios y usted pónganos a funcionar esto.

Esta visión pone de manifiesto un giro total en la estructura y funcionamiento de los consejos comunitarios que preocupa sobre manera en relación con la tradición, identidad y cultura del pueblo negro. Si se rechazaba el desarrollo por la vía de la modernización, no tiene mucho sentido remplazarlo por un modelo empresarial. Idalmy Minota (28 de julio de 2010) en rechazo a esta postura afirma que: 
[...] entendiendo que quizás nos estamos refiriéndonos a un Consejo comunitario como a la estructura administrativa en cabeza de la junta directiva o el representante legal, legalmente el Consejo comunitario está conformado por todos los miembros de la comunidad entonces el tratar de convertir la estructura organizativa del Consejo comunitario, cuyo objeto principal es la administración de su territorio y de sus recursos naturales, en una gerencia de una empresa es prácticamente sesgar el papel a un asunto meramente económico y financiero y eso trasciende lo económico y financiero porque estamos hablando es de la supervivencia y la permanencia de un grupo étnico que tiene una relación cultural con el territorio.

Retomando lo anterior, se puede sostener que las comunidades negras del Medio Atrato no pueden ser entendidas como un ente unitario, en tanto que representan una multiplicidad de posturas en torno a las concepciones sobre la "vida buena". Así que el posdesarrollo debe tomar como presupuesto la pluralidad de las comunidades, sin homogenizar los puntos de vista bajo la lógica de la revaloración de las culturas vernáculas. En este sentido se pudieron observar tres diferentes concepciones en torno al desarrollo: una que parte de la romantización de la cultura local y se focaliza en la captación de recursos de las ONG; una que propugna por convertir los consejos comunitarios en ETAS y que piensa en transformar las lógicas comunitarias en empresas. No obstante a pesar que todas las concepciones del desarrollo son diferentes, se puede sostener en conformidad con la Ley 70 de 1993 que deben tener fundamento en un plan de etnodesarrollo:

[...] nosotros tenemos un plan de desarrollo desde arriba hacia abajo; nosotros queremos un plan de desarrollo de abajo hacia arriba [...] es que la merca suya no le puede llevar pescado, carne, queso huevos si a usted le gustan los frijoles, las lentejas, y la arveja, usted queda mal yo no quiero esta vaina, yo tengo que preguntar usted que va a almorzar, hay si nosotros decimos bueno sentémonos y digan bueno vamos a construir o qué tienen ustedes que todo lo nuestro no es bueno ni todo lo de ellos malo, entonces miremos y pongámonos de acuerdo, ese es el problema no se ha logrado eso [...] como es que van a hacer una carretera por allí si nosotros no queremos esa carretera, nosotros no queremos esa carretera queremos otra cosa que pregunten qué quieren, queremos un hospital más bien en vez de esa carretera o queremos un colegio en vez de la carretera, es eso es lo que le decimos al gobierno cuando se hace con nosotros sentémonos y hay si por ejemplo en el tema educativo nosotros siempre hemos dicho que nosotros queremos la agenda de etnoeducación porque nosotros tenemos un trato diferencial, el trato diferencial también a los 
indígenas y que lo están pidiendo los negros en Colombia y eso es lo que no entiende el gobierno Colombiano (Quejada, 27 de julio de 2010).

Teniendo en cuenta lo dicho en este apartado se puede sostener que las comunidades de base sustentan visiones diferenciales sobre temas centrales como el desarrollo. Así, teniendo en cuenta la pluralidad de los pueblos del Pacífico será preciso atender ahora a los problemas de la organización liberal ideada por la Ley 70 de 1993.

\section{Las paradójicas formas de organización liberal}

En conformidad con lo planteado por Andrés Hernández (2002) se puede hablar de cuatro problemas en la democracia liberal: la distancia entre los representantes y los representados; la imposibilidad de tomar decisiones imparciales; la burocratización de las formas legítimas de organización política, y la agencia. Es presumible pensar que siguiendo el modelo representativo de la Ley 70 de 1993, todos estos problemas se manifiestan de diferente manera; sin embargo antes de tomarlos en consideración se hará referencia a las figuras representativas que contempla la ley y a la propuesta organizativa que el movimiento negro le hizo al Gobierno en el marco del artículo 55.

En conformidad con el Decreto 1745 de 1995 se pueden identificar tres figuras representativas de relevancia: el representante legal la junta, y la consultiva de alto nivel. En cuanto al primero, se debe resaltar que tiene la facultad de solicitar la titulación colectiva del territorio y presentar ante la autoridad ambiental competente y ante el Ministerio de Minas y Energía -MinMinas- la solicitud de aprovechamiento, exploración y explotación de recursos. Solo que, aunque sus facultades parecen excepcionales debe tener autorización previa y aprobación de la junta del Consejo. En otras palabras, el representante está completamente supeditado a la voluntad de este ente rector (Decreto 1745 de 1995, art. 12).

En consecuencia, a pesar que la asamblea general es la máxima autoridad del consejo comunitario al estar conformada por todos los miembros registrados en su censo interno (Decreto 1745 de 1995, Art. 4), se puede decir que la junta al otorgarle al representante legal las facultades antes referidas, es en sentido lato la autoridad rectora del consejo. Ciertamente tiene la ventaja de ser un cuerpo colectivo; aunque teniendo en cuenta que en cada 
comunidad es posible que el proceso organizativo sea abanderado por unos pocos líderes, es viable o bien que todos sean amigos, o bien que siempre sean los mismos los que representan. En este sentido; dado que la junta toma decisiones trascendentes como la explotación de los recursos, es presumible pensar que hay vías hacia la corrupción por medio del favorecimiento de terceros. Esto se cree posible porque aún cuando la asamblea faculta las actividades del representante y de la junta, esta última tiene libertad para: (1) presentar y gestionar planes económicos para su comunidad y (2) administrar el uso, aprovechamiento y conservación de los recursos naturales (Decreto 1745 de 1995, art. 11).

En cuanto a las consultivas de alto nivel de las comunidades negras, se puede decir que fueron creadas para hacer seguimiento a lo dispuesto en la ley 70 de 1993 y para coadyuvar en la reglamentación de cada uno de sus capítulos (arts. 45 y 60). Asimismo en conformidad con el Decreto 3770 de 2008, se puede decir que dentro de las funciones de esta comisión también se cuenta (1) la concertación e interlocución de las comunidades con el Gobierno, (2) buscar consensos y acuerdos con las comunidades que representan y (3) servir de instancia previa de medidas legislativas y administrativas (Art. 12).

Ahora bien, tomando este marco jurídico; se debe anotar que la propuesta de conformar consejos comunitarios no provino de las organizaciones de base de los pueblos negros del Pacífico sino del Gobierno:

[...] logramos después de un año que se conformara la Comisión Nacional Especial que reglamentaria el transitorio 55, en ese proceso de reglamentación por cada uno de los departamentos hay una representaciones por el Chocó estaba Rudelsindo Castro, estaba Saturnino Moreno y estaba yo, Zulia Mena. Los tres por el Chocó y estuvimos en la Comisión que estaba conformada por políticos, por investigadores, por representantes del gobierno, representantes de Comunidades Negras, los comisionados por Comunidades Negras éramos doce si no estoy mal [...] el tema territorial y el tema de los recursos naturales fue el tema más difícil y el tema de la organización, en ese tema de la organización nosotros queríamos que la parte orgánica que adornaba el territorio que lo administraran lo palenques, el gobierno no aceptó, no permitió, como que los palenques estaban cargados de una cantidad de cosas [...] esa gente es muy peligrosos porque se rejuntaron en la época de la esclavitud y la esclavización entonces ellos no permitieron eso y propusieron los Consejos comunitarios; esos Consejos comunitarios son una propuesta del gobierno y la de nosotros era los Palenques (Mena, 27 de julio de 2010). 
En conformidad con la hipótesis planteada por esta investigación, la estructura organizativa de los consejos comunitarios asume una lógica que le es extraña a las comunidades negras del Pacífico. Hay una distancia enorme en términos del imaginario colectivo y la organización de un modelo regido por un consejo en la lógica liberal de las "juntas de acción comunal", y un palenque en las lógicas de emancipación del pueblo negro. Los Palenques en palabras de Zulia Mena (27 de julio de 2010) fueron

[...] históricamente los sitios libres, eran los territorios libres, cuando la población negra los cimarrones se alzaban y defendían su libertad entonces ellos se refugiaban en Palenque, que Palenque quiere decir "territorio libre" entonces los Palenques tienen esa carga de la lucha histórica de los negros, se armaban, hacían barricadas, hacían tomas para poder recuperar sus derechos, entonces Palenque está ligado a cimarrones.

Tomando en cuenta la propuesta y el resultado de la Ley 70 de 1993 es preciso indagar por la estructura organizativa de un Palenque; pues en últimas puede terminar siendo muy similar a un consejo. Al respecto agrega Zulia Mena que:

[...] ellos definían la autoridad según los saberes, había una persona que era el mayoritario y tenía determinado saberes entonces había un reconocimiento de la comunidad y entonces lo elegían y ese que era el más guerrero o el que sabía trabajar más la mina o el que era el curandero del pueblo o el que se ganaba el respeto es al que le daban la vocería, elegían un representante para que ese representante hablara por ellos entonces al interior las mujeres, los niños y los otros tenían cada uno su papel y hacían la junta de negros, hacían las reuniones para hacer el trabajo hacían las mingas, la mano cambiada entones comienza a implementar ahí alrededor de esos Palenques una serie de formas organizativas para ellos reconstruir otra vez su pueblo, tener otra vez su familia porque eran personas que les habían quitado los hijos, que no tenían nada, llegaban con una mano adelante y otra atrás y se juntaban y comenzaban a reconstruir otra vez su vida y generaban su propia organización, entonces los Palenques que eran un territorio libre donde la Comunidad Negra reconstruía su forma propia a nivel de organización, a nivel económico, a nivel cultural ahí se era cuando se moría alguien tenían sus formas como de atenderlos, cuando se enfermaba alguien se intercambiaban y se apoyaban; tiene todo el sistema de solidaridad de los negros que permite que hoy en día en Colombia hayan pueblos todavía negros, la base de que hoy en Colombia seamos más de diez millones son esos Palenques, esos territorios libres que el negro se resguardó y se metió a la selva a reconstruir otra vez sus pueblos y reconstruir su cultura. 
Sin embargo, aunque la propuesta de las comunidades negras en el marco de las negociaciones del artículo 55 fue la de los Palenques, no todas las personas creen que lo ideal es apelar a formas organizativas de este tipo, Idalmy Minota (28 de julio de 2010) sostiene que:

[...] no es un problema de cómo se llama la figura me van a decir que Palenque es una figura que cree en una ley en Colombia y eso es un problema llámalo Consejo comunitario, llámalo junta, llámalo como te dé la gana Palenque significa rebeldía, palenque es ruptura, palenque no es grado de ley al contrario los Palenques los crearon nuestros cimarrones para atrincherarse fue el territorio que ellos liberaron de hecho y en el que se podían refugiar para dar la guerra por la liberación y eso lo pudieron hacer concentraditos con el gobierno, el gobierno dando la plática de los pasajes, el gobierno dando viatiquitos y la ONG auxiliando todo el poco de mochileros Bogotanos y auxiliando y creyendo pues que llegó la revolución, no señor, el tema no es si se llama Consejos comunitarios o se llama junta el tema es qué función cumplo yo dentro de un territorio y yo pienso y soy una convencida de que el Estado Colombiano hizo representación cuando reconoció el derecho que está consagrado en la Ley 70 y en lo que se ha reglamentado hasta hoy todo no sabía dónde iba ese boquete, ellos no sabían se lo juro que donde el Estado colombiano hubiera vislumbrado hasta donde iba a llegar la titulación colectiva no lo reconoce

En estos términos hablar de Palenque no es más que un problema de denominación; así que en lugar de pensar en formas ancestrales se deben idear estrategias de resistencia desde los mecanismos institucionalizados ganados por el pueblo negro. De manera que no es viable pensar en un Palenque si se tiene en cuenta que significaría un retroceso en el proceso organizativo de las comunidades

[...] yo para que meto un Palenque hoy, usted cree que han metido algún Palenque, a mi no llevan con Palenque a pasar trabajo hoy, no señor yo aquí voy es pa delante porque esa es la obligación que tengo con los de atrás, los cimarrones que lucharon antes que yo, nos dejaron un espacio ganado abarcado y ahí es donde yo te estoy hablando de recoger el testimonio yo no puedo ser inferior al legado ancestral y para ser superior al legado ancestral tengo que avanzar políticamente en este bendito Estado (Minota, 28 de julio de 2010).

Bajo estas circunstancias, retomando la postura en defensa de los consejos comunitarios y la postura en defensa de los Palenques; se debe decir que el segundo modelo resulta más consistente con la tradición y cultura del 
pueblo negro, además no introduce lógicas foráneas dentro de la comunidad tales como la representación. Con seguridad se puede decir que Idalmy Minota no está de acuerdo con este modelo debido a que ella ha sido una de las grandes defensoras del mismo, desde su condición de alta consultiva, mientras que Zulia Mena en su papel de negociadora, atiende seguramente, al rol histórico que desempeñó. Sin satanizar ninguna de las dos posturas, solo vale agregar que los consejos representan formas de organización coherentes, aunque pueden no funcionar o no ser tan afines a las lógicas de la cuenca del Pacífico.

A pesar de que los consejos no responden a las lógicas, se debe reconocer como lo sostiene Esildo Pacheco (2010), que antes de la Ley 70 de 1993 las comunidades se organizaban en torno a juntas de acción comunal, lo que quiere decir que el cambio no fue tan abismal. Perenne esto no quiere decir que en su momento las organizaciones campesinas lograran acaparar los intereses de toda la comunidad. Lo que sí se debe reconocer en relación con los consejos es que lograron asumir una dinámica propia en contravía con lo que pretendía el Gobierno

[...] "cada Comunidad Negra podrá conformar un Consejo comunitario" el Gobierno quería que conformáramos un poco de consejitos, nosotros dijimos no, nosotros estamos luchando por un proyecto de vida como pueblo entonces a nosotros nos toca agrupar varias comunidades para formar un gran Consejo comunitario y asegurar un gran territorio que nos permita mantenernos como pueblo, entonces nosotros definimos la cuenca de los ríos como la unidad de planificación de la Comunidad Negra y en una cuenca de un río usted consigue un poco de comunidades entonces nosotros gracias a Dios logramos eso [...] eso era un reto sacar el título más grande que era el de COCOMACIA y le apostamos a eso y lo sacamos y estaba yo en el congreso y trajimos a Samper a firmar el título de COCOMACIA al frente del río Atrato lo firmó aquí y a partir de ahí ya siguieron todos los demás (Mena, 27 de julio de 2010).

De acuerdo con la Ley, dicen las comunidades, el Gobierno pretendía conformar una serie de consejos pequeños; quizás con el propósito de manipular de forma más sencilla a cada pueblo. Sin embargo, las comunidades lograron organizarse y con base en el referente geográfico de la cuenca de los ríos consolidaron consejos mayores como COCOMACIA, pero al hacerlo surge una gran duda en torno a la representación de la comunidad; pues a pesar de que lograron el cometido de titular el territorio, queda por estable- 
cer si en realidad lograron abarcar los intereses de todos los pobladores. $\mathrm{Al}$ respecto afirma Richard Moreno que:

[...] la estructura está bien pensada con excepción de lo que pasó con ese esguince que tuvieron con el representante legal de sacarlo de hacer parte de la junta, creo que está bien pensada en el sentido que son tres intancias que las dos últimas o sea la junta directiva y el representante legal lo eligen la asamblea, eligen una asamblea general o los eligen una asamblea general que en términos de voz de catorce años en adelante pueden votar pueden perdón participar en términos de votos los mayores de dieciocho años que creo que en ese sentido, pero a demás salimos mas allá, la ley le asignó unas funciones tanto a la asamblea como a la junta directiva y el representante legal, pero se señaló una cosa que es lo más novedoso que tiene la ley y estableció la posibilidad de que establezcan sus propios reglamentos internos SINO esos reglamentos internos se regulan otras situaciones que no están contempladas en la ley para el representante legal y para la junta directiva y para la misma asamblea entonces yo creo que la estructura como tal es funcional, funcional en el sentido de que bueno hay una máxima autoridad que es la asamblea pero como todos no puede mandarse tampoco la ley también establece que hay necesidad de que se elijan los miembros de la junta por tronco familiar o sea eso que significaría que la gran mayoría de la familia queda representada en la junta directiva ya el representante legal pues normalmente se eligen a la persona que tiene mayor grado de conocimiento de la comunidad, mayor legitimidad y sobre todo mayor credibilidad comunitaria

Teniendo en cuenta lo anterior una postura común dentro de los líderes campesinos y los representantes de los consejos es que la figura de la representación esté bien diseñada, siempre y cuando se sustente en la Ley

[...] porque el representante legal firma un poder pero cuando la junta directiva del Consejo comunitario le da el aval para que firme si no le da el aval no puede firmar, es decir, son diez, son siete o son nueve directivos de esos nueve es que le dan el aval al representante legal para que el no haga guacas independientes eso por un lado, pero también le digo otra cosa es que el representante legal a veces se levanta con el santo de la limosna como decimos en el Chocó, sin contentar con la junta directiva sin contentar con la comunidad hace cosas indebidas y ha habido muchos casos de esos y eso es muy delicado, es muy peligroso porque se van a Medellín a Bogotá lo llevan a un hotel le dan whiskey le dan una vuelta en un auto y llega y firma y vendió los intereses de la comunidad, eso se ha visto y se sigue viendo pero nosotros venimos trabajando frente a eso que le llamamos líderes vendidos, líderes sin conciencia y líderes que no respetan, hay otros representantes legales porque 
legalmente el período legal del representante legal o de la junta directiva son tres años y el Decreto 1745 que si han hecho las cosas bien son reelegidos una sola vez, o sea, elegido y reelegido una sola vez, no puede ser dos ni tres veces, pero ellos cuando las cosas le gustan y quieren estar ahí se hacen los locos, nunca buscan los recursos para que haya asamblea se les pasó el período y están tranquilos y siguen siendo representante legal hasta cuatro, cinco, seis y siete años, cuando uno los aprieta y va a hacer asambleas se enojan a veces que ni van a la asamblea, o sea, uno a espalda de ellos tiene que proceder cumpliendo lo que dice el Decreto 1745 y dice vea me sacaron, se aliaron y entonces yo me voy para otro lado porque no es justo lo que hicieron conmigo pero el injusto es él porque no reconoce que lleva siete años ahí ilegal (Quejada, 27 de julio de 2010).

Eso significa que la figura del representante legal está bien pensada en la medida que está controlada por la junta y además está reglamentada para durar tres años. Sin embargo, como el mismo Aurelino Quejada (2010) lo sostiene estas figuras están sujetas al problema de la agencia, pues se tiene en cuenta que "venden los intereses de la comunidad" y se perpetuán en sus cargos.

Ciertamente hace falta un control político que garantice el ejercicio de las tareas para las que están designados los representantes. Empero, contrario a lo que se podría pensar las comunidades insisten en que el problema no es de la representación sino de las personas

[...] el problema está más en el individuo que el proceso comunitario, hay unos solos líderes que se abanderan del proceso de Comunidades Negras para sacar partido político o sea para sacar un beneficio político por decir algo "Pedro Pérez tiene como objetivo de vida llegar a ser alcalde" y él sabe que meterse al proceso de las Comunidades Negras en una coyuntura interesante porque va a estar codeándose con las comunidades desde las bases pero él su objetivo no es ayudar a solucionar el problema de Comunidades Negras es ver cómo logra ese caudal de electores para su propio beneficio político o politiquero, diría yo más bien politiquero, entonces él se muestra como un líder que representa a las comunidades que lucha por ellas pero en el trasfondo esa no es la idea (Arcila, 27 de julio de 2010).

Bajo esta consideración, Guillermo Arcila insiste en que el modelo del representante legal está bien pensado y que el problema es el individualismo que se le ha inculcando a los miembros de la comunidad. Pero, si es tan insistente la defensa en el modelo representativo ¿Qué se puede decir de las 
altas consultivas? Al respecto señala el padre Ulrich Kolwitz (29 de julio de 2010) que

[...] ése es un espacio totalmente manipulado, las altas consultivas no representan a las bases, aquí he sido testigo de primera mano de eso pero hablando también con gente de otras regiones me cuentan que se repite el mismo esquema, que personas con intereses personales o intereses politiqueros o económicos han sabido ocupar estos espacios, han sabido manipular junto con los políticos, pues para que salgan cada vez reelegidos a pesar de que no tienen representación de las bases, eso es lo que es difícil entender que las comunidades a pesar de que han caído hace tres años hace seis años ahora vuelven a caer nuevamente en un proceso de manipulación y permiten que salgan nuevamente las mismas personas hay elegidas y que siguen representando entre comillas a las comunidades pero no representan a las comunidades.

Idalmy Minota (28 de julio de 2010) en contravía con la lectura de Zulia Mena sobre la titulación de los consejos mayores sostiene que el problema de la representación no tiene que ver con la figura ni con las personas, sino con la interpretación que las comunidades, y sobre todo las organizaciones campesinas hacen de la ley:

[...] lo que pasa es que cuando la figura se crea, se concibe sin mirar la ley, se concibe en una comunidad pequeña que es la comunidad local entonces si es la comunidad local digamos como lo están haciendo algunas comunidades muy poquitas yo sola mi comunidad constituyó mi célula y constituyó mi título y funciona porque la junta debe integrarse con representación de los troncos familiares que conforman la comunidad esa es la filosofía; pero lo que no prohíbe la ley y se hizo en mi opinión insisto de mala manera fue juntar cincuenta comunidades, sesenta comunidades, ochenta comunidades, ciento veinte comunidades en un Consejo comunitario ahí es donde vos tienes el problema de si funciona o no funciona la junta.

Es claro que existe un problema con las figuras del representante legal y la consultiva de alto nivel. A pesar que se defiende y se arguye que el problema radica en las personas; habría que decir que si el modelo organizativo estuviera bien estructurado no habría lugar a suponer que el problema es de ellas. En estos términos, es claro que existe una separación entre los representantes y los representados en la medida que la alta consultiva por ejemplo, a pesar de ser elegida no representa los intereses de las bases. Existe un problema de burocratización en tanto que el representante ter- 
mina escindiéndose de su comunidad, sobre todo si se tiene en cuenta que muchos tienen su oficina en Quibdó y pocas veces pueden ir a visitar el territorio que administran; existe un problema de imparcialidad dado que las decisiones en torno a la explotación de los recursos son tomadas por el consejo sin necesidad de la aprobación de la asamblea. En otras palabras, los intereses de todos los miembros de la comunidad puede que no estén representados a cabalidad en los miembros de la junta; y aún así se toman decisiones trascendentales de carácter económico como el usufructo de la tierra. Finalmente existe un problema de agencia porque las comunidades no cuentan con herramientas de control político para evaluar la gestión de sus representantes y garantizar el cumplimiento de su labor.

\section{Prolegómenos a un modelo deliberativo de organización}

Este apartado toma como fundamento los problemas del modelo liberal de organización de los consejos comunitarios. Consciente de la enorme dificultad de la democracia para lograr abarcar todos los miembros de una comunidad en el marco de un proceso de toma de decisiones. Se asume como "tipo ideal" el modelo de democracia deliberativa. Se debe aclarar que no se encontrará una estructura organizativa clara de cara a solucionar los problemas de la representación; solamente se fijarán lineamientos desde los que sea posible en un momento ulterior proponer una estructura organizativa diferente a la del consejo comunitario.

Este apartado se dividirá en dos partes: en primer lugar se centrará la atención en el modelo de COCOMACIA; de tal forma que se tomará en consideración sus virtudes, reconociendo cuales han sido los aportes a la solución del problema de la organización; y en segundo lugar se plantearán cuatro lineamientos generales, que desde la democracia deliberativa puedan servir para pensar una estructura diferente, en la que toda la comunidad sea incluida y en la que la representación no sea una barrera para el desarrollo de los pueblos del Medio Atrato.

En cuanto a la organización de COCOMACIA es preciso reconocer que no solo es una organización campesina pionera en el proceso de titulación colectiva, sino que además es una organización abanderada del proceso organizativo de las comunidades negras en el Pacífico. Esildo Pacheco (29 de julio de 2010) aduce que: 
[...] la organización tiene dieciocho mil setecientos cincuenta y un socios miembros del título colectivo de trescientas setenta y cinco mil y pico de hectáreas en una cuenca [...] hay un título marco general, pero este título tiene treinta siete Consejos comunitarios Locales treinta y siete y cada Consejo comunitario Local tiene una junta con diez personas [...] entonces estos dieciocho mil habitantes si los divido en treinta y siete ¿cuánto me da? Por debajo de quinientos, entonces ya una junta en su territorio pequeño tiene autonomía de control para ellos.

Teniendo en cuenta esta organización, es preciso reconocer que el funcionamiento del consejo mayor se da a través de una "representación escalafonada", pues dicho órgano se divide en zonas y éstas a su vez en comunidades

COCOMACIA es el marco del ámbito territorial grande de todos los Consejos comunitarios Locales que en este momento son ciento veinticuatro, esos ciento veinticuatro están repartidos en nueve zonas, cada zona hay unas doce comunidades, hay otras en trece así por el estilo varían la población que hay dentro de la zona y todo esto obedecen al Consejo comunitario Mayor y de estos para las asambleas se escogen tres personas por cada Consejo comunitario Local y cinco personas por la zona, entonces esta gente va con derecho a voz y voto siempre y cuando esté a paz y salvo en sus cuotas trimestrales, entonces de allí ya en el mecanismo que se tiene actualmente las zonas eligen directamente al representante de la junta (Mosquera, 30 de julio de 2010).

Siguiendo a Florentino Mosquera, un líder campesino de la ACIA se puede decir que el consejo comunitario busca darle participación a las comunidades de base, de tal forma que todas se sientan incluidas en las decisiones. Por esta razón a pesar que son 124 comunidades, éstas no son administradas por todo el consejo; sino que se dividen en nueve zonas de tal forma que pueda haber más comunicación con las bases. En este sentido, cada una de estas comunidades está conformada como consejo local y por ende cuenta con las figuras del Decreto 1745 de 1995: la asamblea, la junta y el representante legal.

Retomando a Florentino Mosquera (2010) se puede inferir que de las 124 comunidades se forman nueve zonas, que a su vez vinculan nueve consejos locales. En estas zonas cuando se va a hacer una asamblea participan cinco miembros de cada comunidad, así que en total asisten 60. De estos se elije uno solo que es el que representa a la zona en la junta del consejo mayor. 
De manera que cinco personas representan cada consejo local; 60 personas representan cada zona de 12 consejos locales; y nueve personas representan 124 comunidades del consejo mayor.

Dicho lo anterior, es posible afirmar que el modelo organizativo de la ACIA es inquietante en términos de la representación, sobre todo si se tiene en cuenta que logra reunir a las comunidades y mantener cercanía con todas ellas, descentralizando el poder en diferentes zonas y evitando que recaiga sobre una sola persona. No obstante; se debe decir que el proceso se encuentra abanderado por unos líderes dentro de cada comunidad y en el consejo mayor, lo que hace que éste siga estando distante de las bases. En otras palabras, el líder de cada comunidad termina no reuniendo los intereses de todos los miembros que representa y el líder de la zona termina no representando los intereses de todos los consejos locales que representa. De manera que aun cuando es interesante el modelo, se debe reconocer que sustenta tendencias hacia la burocratización, la falta de imparcialidad, el favoritismo, la falta de control político, y lo más grave, una separación entre los representantes y los representados.

Hay un problema adicional y es que entre los nueve miembros de la junta del consejo mayor es mucho más factible que se presenten posiciones afines, más aún si son personas que se conocen o incluso si son amigos. Lo más preocupante de todo es que las comunidades de base suponen homogeneidad de pensamiento en relación con el representante de su comunidad y como se vio en los apartados anteriores, es claro que existe una diversidad de concepciones en torno a lo bueno y por ende la representación termina por suprimir esta diversidad.

En consecuencia, se puede decir que aunque el modelo de representación de la ACIA es interesante, reproduce los mismos problemas del modelo liberal de democracia; de manera que en conformidad con lo planteado por Idamy Minota (2010), se cree que es necesario conformar consejos más pequeños en los que la comunidad tenga una participación verdadera dentro de las decisiones sobre su territorio y sobre su vida. Más aún, se piensa que para lograr una verdadera interlocución y un auténtico gobierno de la discusión, es preciso que dichos órganos sean pequeños, de lo contrario el campesino que no es líder, quedará excluido de las decisiones y no podrá manifestar sus puntos de vista. 
Esto no quiere decir que el proceso de la ACIA se vaya a dejar a un lado; por el contrario, se debe potenciar con competencias diferentes y con estructuras que piensen otros modos de relacionarse con las comunidades. Es importante agregar que aún cuando se debe dar a conocer la Ley a todas las comunidades; no es conveniente que ésta sea presentada por los líderes y por la ACIA de cara a legitimar el proceso sin que haya lugar a diferendos en términos de las lecturas o las concepciones de la comunidad.

Ahora bien, teniendo en cuenta que se aboga por consejos locales en lugar de consejos mayores, se parte del modelo ancestral del palenque y por ende de la figura emblemática del vocero

En la reglamentación hay que tener varios elementos en cuenta primero en las Comunidades Negras hay unas organizaciones naturales hay una forma de organización natural que no tiene control oficial sino que la gente la establece y no se eligen como yo le decía al dedo, no se elije en una asamblea no se elijen porque sea el que más habla, porque sea el que más títulos tenga, o el que más plata mas modo tenga en la comunidad, se elijen porque es el más servicial, se elijen porque es el que más conoce tal tema, se elijen porque usted es el más respetuoso, se elijen porque usted es la persona más decente, se elijen porque usted es la persona que en cualquier momento que la necesiten esta allí y su representación tiene que ver con la gente antes que ir allá viene acá y habla con la gente y lo que él dice es porque es un acuerdo eso eran las juntas de negros antes el vocero simplemente lleva la vocería de lo que acuerdan acá en la junta (Mena, 27 de julio de 2010).

Se plantea una diferencia enorme entre el representante legal y el vocero, pues éste a diferencia del primero tiene la tarea de compartir con la gente y de discernir con ella. El vocero no se separa de la comunidad y mucho menos se escinde de la misma en procesos de burocratización, sino que supone una interlocución de los intereses de la comunidad con los intereses de fuera. Bajo estas condiciones es preciso pensar en los requisitos que debe reunir la discusión dentro de una comunidad local.

De este modo, con base en los planteamientos rawlsianos, se debe reconocer que todos los miembros de la comunidad deben asumir un velo de ignorancia a través del cual supriman sus condiciones particulares y puedan discutir a favor del interés general y sin procura de un beneficio individual; sin embargo, teniendo en cuenta que se está hablando de comunidades rurales y que el procedimiento puede resultar abstruso y hasta insulso, se puede 
abogar más bien, en la línea del consenso entrecruzado; por el hecho de que la discusión tenga ciertas reglas entre las que se debe asumir que cada uno de los individuos explique su punto de vista de manera consistente y coherente ante la sociedad. De este modo, sobre la base del entendimiento los demás podrán tener la libertad de sumir su postura o rechazarla (Mejía, 1994).

El segundo elemento a considerar en orden a instaurar un modelo deliberativo de democracia es el alusivo al principio discursivo del que habla Habermas. De acuerdo con este principio solo se podrán asumir como válidas las decisiones tomadas en el marco de una discusión sobre la base de discursos racionales -comprensibles-; de tal forma que todos los que se vean afectados por las decisiones hayan tenido la oportunidad de participar en la toma de éstas (Cortés, 1996).

El tercer elemento a tener en cuenta se refiere a las tres condiciones que debe reunir la deliberación, a juicio de Roberto Gargarella (2001) se debe obligar a los miembros de la comunidad a cambiar sus argumentos a fin de volverlos aceptables para todas las personas; también se debe vincular el papel de la educación de tal forma que los miembros de la comunidad sean formados para la imparcialidad -quiere decir que se debe capacitar a la comunidad-; y tercero, las partes de la discusión deben reconocer sus propias posturas, de tal forma que estén dispuestos a aclarar y purificar su posición.

Finalmente, en términos de Fraser (1997), la esfera pública para la deliberación de los problemas comunes es el espacio institucionalizado del consejo comunitario local. No es pensable un escenario más extenso dada la importancia de un modelo participativo e inclusivo; cualquier otro espacio termina atentando contra la cultura del pueblo negro, y por ende termina deviniendo en una burocracia occidental. 



\section{CONGLUSIONES}

Z sta investigación partió de la premisa que el problema Cde la organización liberal de los consejos comunitarios no había sido abordado por la literatura de comunidades negras. Al respecto se indagó por los diferentes conflictos a los que se había visto sometido el pueblo afro descendiente desde su reconocimiento como grupo étnico; haciendo alusión también a los trabajos que de diferente modo se acercaron al tema del desarrollo desde el punto de vista de la organización de las comunidades se atendió igualmente a la literatura que se había ocupado del tema de su etnización en Colombia, situando con especial énfasis la Ley 70 de 1993 y finalmente se centró la atención en los trabajos que se ocuparon del tema de la mujer dentro del proceso organizativo.

La formación de los consejos comunitarios sustenta una paradoja en tanto que se produce simultáneamente con el desplazamiento de la violencia hacia el Pacífico. Es importante anotar que la bibliografía sobre este tema es prolífica sobre todo porque el auge de los paramilitares y la aparición de estas "geografías de terror" se producen al mismo tiempo que el reconocimiento de los derechos étnico-territoriales. La violencia no es el único problema que mueve a los campesinos del Pacífico a organizarse, también los proyectos agroindustriales y los grandes capitales interesados en explotar la zona hacen que el territorio de la cuenca del Pacífico sea propicio para un movimiento de comunidades negras.

Uno de los temas en los que más se profundizó sobre todo desde la antropología, fue el tema de la etnización del pueblo negro. Como se mostró en el capítulo tercero y 
desde la perspectiva de Carlos Agudelo (2005), aún cuando los pueblos del Pacífico tienen ciertas tradiciones, prácticas culturales y valores que le son propios, es casuístico el uso que se da, lo que quiere decir que o bien se da un uso instrumental de estas prácticas como mecanismo para reclamar derechos étnicos y territoriales, hipótesis nada encomiable; o se puede pensar que la proliferación de la violencia hacia el Pacífico durante los años 90 y el impacto de los megaproyectos y el capital, produjeron una transformación en las dinámicas culturales de esta población. Lo cierto es que desde cualquiera de las hipótesis se puede decir que el discurso de la etnización es central en la conformación de los consejos comunitarios, pues de cualquier manera la Ley 70 de 1993 les reconoce derechos étnico-territoriales a las comunidades negras.

Existe un vacío notable en relación con los trabajos que se han ocupado del papel de la mujer dentro del proceso organizativo de las comunidades negras. La razón que se puede dar es que las reivindicaciones del movimiento hasta ahora han tenido orientaciones de otra índole: étnicas y territoriales. Se esperar que en el futuro se realicen trabajos sobre el tema; aunque de momento es extraño este vacío, teniendo en cuenta que el papel de la mujer es ambiguo en el movimiento, ya que existe una división sexual del trabajo pero la mujer ocupa un papel esencial dentro de la familia y la estructura social afrodescendiente. Eso indica que cualquier emancipación de este sujeto dominado debe arrancar con una concienciación de la misma mujer, pues es ella quien reproduce y defiende las estructuras de dominación.

Se asumieron dos marcos teóricos; de un lado el posdesarrollo sobre el que se dijo que rechazaba las teorías del desarrollo y asumía la revaloración de las culturas vernáculas; y la democracia deliberativa sobre la que se afirmó que planteaba críticas a la concepción liberal de la democracia y proponía un gobierno fundado en la discusión. Ciertamente los aportes de estas perspectivas teóricas fueron significativos, pues además de inducir a relaciones teóricas entre los marcos conceptuales, permitieron dilucidar el fenómeno de los consejos comunitarios desde una perspectiva diferente; la perspectiva de la organización.

En cuanto al trabajo de campo presentado en el tercer capítulo y analizado con base en los dos marcos teóricos, se pudo ver que las prácticas 
comunitarias no solo se reducen al territorio sino que también involucran otras esferas como los velorios y los entierros. Hecho que llevó a establecer que el argumento de la etnicidad del pueblo negro de la Cuenca del Pacífico no fue instrumental de cara a titular los territorios, sino que representa una estructura intrínsecamente comunitaria.

Sin embargo, en relación con el territorio se encontró que contrario a lo que se podría pensar, en el Medio Atrato conviven formas de apropiación privada con formas de apropiación comunitaria, de manera que la titulación colectiva no representa una propiedad ancestralmente comunitaria; sino que representa una estrategia para garantizar la propiedad del territorio, aún cuando dentro de cada título convivan formas privadas de apropiación. No obstante, se agregó que estos rasgos de individualismo no representan ninguna vulneración respecto a las prácticas vernáculas.

Se mostró que la idea del desarrollo de los consejos comunitarios divide de forma abrupta a los actores del proceso organizativo; mientras unos creen que se debe convertir los consejos en empresas; otros suponen que lo mejor es transitar hacia ETAS; mientras que otros piensan que lo ideal es reafirmar las prácticas tradicionales y captar recursos de las ONG. Estas diferentes visiones llevaron a suponer que el posdesarrollo debe sufrir una reformulación, o al menos debe establecer una claridad sobre el papel de las comunidades dentro de las concepciones de lo que quieren, pues se puede pensar en una homogenización de las comunidades cuando en realidad el pensamiento de éstas es múltiple.

Bajo estas circunstancias se llegó al punto central de la investigación donde se demostró que la organización de los consejos comunitarios sustenta un problema en torno a la forma liberal de organización. Sin lugar a dudas, la figura del representante y de la consultiva de alto nivel dejan en evidencia problemas en la separación de los representantes y los representados, en la burocratización, en la imparcialidad y en la agencia. A pesar que los entrevistados insistían en que las figuras estaban bien pensadas y que el problema era de las personas; se adujo que la falta de control político es un vacío de la democracia liberal y que por ende si la dificultad era de las personas necesariamente era del modelo.

Por tanto, se llega finalmente a suponer que el modelo ideal de organización para los consejos comunitarios debe estar fundado sobre la democracia 
deliberativa. De manera que se plantearon cuatro lineamientos de cara a pensar en un proceso organizativo en el que las comunidades tuvieran una mayor participación y en el que se lograran resolver los problemas del modelo liberal. En este sentido, se apeló al modelo rawlsiano del consenso entrecruzado, el principio discursivo habermasiano, la imparcialidad de Gargarella y la esfera pública de Fraser. Así es que, aún cuando se dejó abierta para un trabajo posterior la formulación de una forma de organización deliberativa de las Comunidades Negras del Medio Atrato, se cree haber dejado en el lector la duda en torno a las formas de organización liberal de los consejos comunitarios. 


\section{REFERENCIAS}

Acuerdo de Buchadó. (1987, junio 21). Recuperado de http:// www.ram-wan.net/restrepo/documentos/diar.pdf

Agier,M., \&Hoffmann, O.(1999). Las tierras de las comunidades negras en el Pacífico colombiano: interpretaciones de la ley, estrategias de los actores. Territorios, Revista de estudios Regionales y Urbanos, 2, 53-76.

Agudelo, C. (2005). Retos del Multiculturalismo en Colombia. Política y Poblaciones Negras. Medellín: La Carreta Social.

Almario, O. (2003). Los renacientes y su territorio, ensayos sobre la etnicidad negra en el Pacífico sur colombiano. Colección pensamiento político contemporáneo. Medellín: Fundación Ciudad Don Bosco.

Arcila, G. (27 de julio de 2010). Entrevista Representante Comunidades Negras Corporación Autónoma Regional para el Desarrollo Sostenible del Chocó -[CODECHOCO]. Representante legal Consejo Comunitario local de San José. Quibdó.

Asociación de Consejos Comunitarios y Organizaciones del Bajo Atrato - [ASCOBA]. (2010) ¿Son los mestizos sujetos de derechos en el marco de la ley 70 de 1993? Palmo a Palmo, 4, 5-7.

Ayala, H. (26 de julio de 2010). Entrevista Administrativo, Instituto de Investigaciones Ambientales del Pacifico. Quibdó.

Chaparro, S. (30 de julio de 2010). Entrevista Profesor e investigador de la Universidad Tecnológica del Choco. Quibdó.

Consejo Comunitario Mayor de la Asociación Campesina Integral del Atrato - [COCOMACIA]. (2002). Medio Atrato: Territorio de vida. Bogotá: Red de Solidaridad Social. 
Cohen, J. (2001). Democracia y libertad. En J. Elster (Ed.), La democracia deliberativa (pp. 235-288). Barcelona: Gedisa.

Consejo Nacional de Política Económica y Social - [CONPES]. (1992). Programa BID - Plan Pacífico: una nueva estrategia de desarrollo sostenible para la costa pacífica colombiana. PND: la Revolución Pacífica. (Documento CONPES 2589). Bogotá: Autor.

Consejo Nacional de Política Económica y Social - [CONPES]. (1996). Plan de desarrollo integral del Alto Patía. PND: el salto social. (Documento CONPES 2892). Bogotá: Autor.

Consejo Nacional de Política Económica y Social - [CONPES]. (1997). Programa de apoyo para el desarrollo y reconocimiento étnico de las comunidades negras. PND: el salto social. (Documento CONPES 2909). Bogotá: Autor.

Consejo Nacional de Política Económica y Social- [CONPES]. (2002a). Política para la población afrocolombiana. PND: cambio para construir la paz. (Documento CONPES 3169). Bogotá: Autor.

Consejo Nacional de Política Económica y Social - [CONPES]. (2002b). Programa para la reconstrucción y desarrollo sostenible del Urabá antioqueño y chocoano y Bajo y Medio Atrato. PND: cambio para construir la paz. (Documento CONPES 3180). Bogotá: Autor.

Consejo Nacional de Política Económica y Social - [CONPES]. (2004). Política de acción afirmativa para la población negra o afrocolombiana. (Documento CONPES 3310). Bogotá: Autor.

Consejo Nacional de Política Económica y Social - [CONPES]. (2006). Política de Estado para mejorar las condiciones de vida de la población de Buenaventura. (Documento CONPES 3410). Bogotá: Autor.

Consejo Nacional de Política Económica y Social - [CONPES]. (2007). Política de Estado para el Pacífico colombiano. (Documento CONPES 3491). Bogotá: Autor.

Consejo Nacional de Política Económica y Social - [CONPES]. (2008). Política de promoción social y económica para el departamento del Chocó. (Documento CONPES 3553). Bogotá: Autor.

Consejo Nacional de Política Económica y Social - [CONPES]. (2010). Política para promover la igualdad de oportunidades para la población negra, afrocolombiana, palenquera y raizal. (Documento CONPES 3660). Bogotá: Autor.

Constitución Política (1991). Congreso de la República de Colombia. Colombia. 
Cortés, F. (9 de Junio de 1996). El liberalismo y la democracia deliberativa de Habermas. El Colombiano, pp. 13-15.

Decreto 1745 de 1995. Por el cual se reglamenta el Capítulo III de la Ley 70 de 1993, se adopta el procedimiento para el reconocimiento del derecho a la propiedad colectiva de las "Tierras de las Comunidades Negras" y se dictan otras disposiciones. Diario Oficial No. 42.049. Presidencia de la República (1995, octubre 12).

Decreto 3770 de 2008. Por el cual se reglamenta la Comisión Consultiva de Alto Nivel de comunidades negras, afrocolombianas, raizales y palenqueras; se establecen los requisitos para el registro de consejos comunitarios y organizaciones de dichas comunidades y se dictan otras disposiciones. Diario Oficial No. 47.123. Ministerio del Interior y de Justicia de la República de Colombia (2008, septiembre 5).

Escobar, A. (1988). Power and Visibility: development and invention and management of the third world. Cultural Anthropology, 3(4), 428-443.

Escobar, A. (1995). Imagining a post-development era. En J. Crush (Ed.), Power of development . London: Routledge.

Escobar, A. (1996). La invención del Tercer Mundo Construcción y deconstrucción del desarrollo. Bogotá: Norma.

Escobar, A. (2005a). Más Allá del Tercer Mundo Globalización y Diferencia. Bogotá: Instituto Colombiano de Antropología e Historia - [ICANH]; Universidad del Cauca.

Escobar, A. (2005b). El « postdesarrollo » como concepto y práctica social. En D. Mato (Coord.), Políticas de economía, ambiente y sociedad en tiempos de globalización (pp. 17-31). Caracas: Universidad Central de Venezuela.

Escobar, A. (2006). Post-development. En D. A. Clarck (Ed.), The Elgar Companion Development Studies (pp. 447-451). Massachusetts: Edward Elgar Publishing.

Escobar, A. (2008). Una Minga para el Postdesarrollo. América Latina en Movimiento, 430, 26-30.

Escobar, A. (2010). Territorios de diferencia: Lugar, movimientos, vida, redes. Popayán: Envión Editores.

Esteva, G. (2009). Más allá del desarrollo : la buena vida. América Latina en Movimiento, $445,1-5$.

Everett, M. (1997). The Ghost in the Machine: Agency in «Poststructural» Critiques of Development. Anthropological Quarterly, 70(3), 137.

Fraser, N. (1997). Iustitia interrupta: reflexiones críticas desde la posición "postsocialista». Bogotá: Siglo del Hombre Editores. 
Gargarella, R. (2001). Representación plena, deliberación e imparcialidad. La democracia deliberativa. Barcelona: Gedisa.

Grueso, L., \& Arroyo, L. A. (2007). Las mujeres y la defensa del lugar en las luchas del movimiento negro colombiano. Las mujeres y las políticas del lugar (pp. 113-130). México D.F.: Universidad Nacional Autónoma de México .

Habermas, J. (1998). La política deliberativa: un concepto procedimental de democracia. Facticidady Validez. Madrid: Trotta.

Habermas, J. (1999). La Inclusión del Otro Estudios de Teoría Política. Barcelona: Paidos.

Hernández, A. (2002). El pensamiento republicano frente al déficit de la democracia liberal. Republicanismo contemporáneo: igualdad, democracia deliberativa y ciudadanía (pp. 531-564). Bogotá D.C.: Siglo del Hombre Editores.

Hoffmann, O. (2002). Del territorio étnico a la ciudad: las expresiones de identidad negra en Colombia a principios del siglo XXI. Territorio y cultura. Territorios de conflicto y cambio sociocultural (pp. 277-307). Manizales: Universidad de Caldas.

Hoffmann, O. (2003). Espacios y movilidad de la gente negra en el Pacífico sur colombiano: ¿hacia la construcción de una 'sociedad regional'? Revista de estudios afrobrasileras, 25(1), 43-74.

Hoffmann, O. (2007). Identidad-espacio: relaciones ambiguas. En M. Estrada \& P. Labazée (Eds.), Globalización y localidad: espacios, actores, movilidades e identidades (pp. 431-450). México: CIESAS-IRD.

Kollwitz, U. (29 de julio de 2010). Entrevista Comisión Vida, justicia y paz, Diócesis de Quibdó. Quibdó.

Ley 2 de 1959. Por el cual se dictan normas sobre economía forestal de la Nación y conservación de recursos naturales renovables. Congreso de la República (1959, diciembre 16).

Ley 70 de 1993. Por la cual se desarrolla el artículo transitorio 55 de la Constitución Política. El Congreso de Colombia. Diario Oficial No. 41.013. Congreso de la República (1993, agosto 31).

Martínez, S. P. (2010). La política de titulación colectiva a las comunidades negras del Pacífico colombiano: una mirada desde los actores locales. Boletín de Antropología Universidad de Antioquia, 24(41), 13-43.

Mejía, O. (1994). Justicia y liberalismo político: la obra de John Rawls. Ciencia Política: revista trimestral para América Latina y España, 35, 71-84.

Mejía, O. (2010). Modelos alternativos de democracia deliberativa. Una aproximación al estado del arte. Revista Co-herencia, 7(12), 43-79. 
Mena, Z. (22 de julio de 2010). Entrevista Representante Comunidades Negras. Ex congresista por las Comunidades Negras (1994-1998). Ex candidata a la alcaldía de Quibdó. Quibdó.

Meza, G. A. (2010). Tradiciones elaboradas y modernizaciones vividas por pueblos afrochocoanos en la vía al mar. Antropología en la Modernidad. Bogotá: ICANH.

Mill, J. S. (1998). Sobre la libertad. Madrid: Alianza.

Minota, I. (28 de julio de 2010). Entrevista Consultiva de alto nivel para las Comunidades Negras por el departamento del Choco. Quibdó.

Montenegro, L. (2002). Movimientos sociales de comunidades negras en el Pacífico colombiano y perspectiva de género. Maguaré, 15, 80-113.

Moreno, R. (27 de julio de 2010). Abogado Asociación Campesina Integral del Atrato -[ACIA]. Quibdó.

Mosquera, S. (2009). Antropofauna Afrochocoana Un estudio cultural sobre la animalidad. Ma Mawu (Vol. 11). Quibdó: Universidad Tecnológica del Chocó - [UTCH].

Mosquera, F. (30 de julio de 2010). Entrevista Líder Asociación Campesina Integral del Atrato - [HACIA] (comunidad de Tangui), Coordinador zona 3 Consejo Comunitario Mayor de la Asociación Campesina Integral del Atrato [COCOMACIA].

Oslender, U. (2004). Geografías de terror y desplazamiento forzado en el Pacífico colombiano: conceptualizando el problema y buscando respuestas. En E. Restrepo \& A. Rojas (Eds.), Conflicto e (in) visibilidad, retos en los estudios de la gente negra en Colombia. Popayán: Universidad del Cauca.

Oslender, U. (2008). Comunidades negras y espacio en el Pacifico colombiano: hacia un giro geográfico en el estudio de los movimientos sociales. Cali: Instituto Colombiano de Antropología e Historia; Universidad Colegio Mayor de Cundinamarca; Universidad del Cauca.

Pacheco, D. (28 de julio de 2010). Entrevista Representante legal de las asociaciones campesinas del Choco. Quibdó.

Pacheco, E. (29 de julio de 2010). Entrevista Líder comunitario. Ex secretario operativo de la Comisión Nacional que legislo para los derechos de las Comunidades Negras. Quibdó.

Pertuz, R. (2007). Derecho a la alimentación y al territorio en el Pacifico colombiano. Colombia: MISEREOR.

Proceso de Comunidades Negras - [PCN]. (2008, Febrero 29). Territorio y conflicto desde la perspectiva del Proceso de Comunidades Negras PCN; Colombia (Reporte final). Cali: Autor. 
Quejada, A. (27 de julio de 2010). Entrevista Representante legal del Foro Interétnico Solidaridad Choco. Quibdó.

Rahnema, M. (1997). Towards Post-development: Searching for Signposts, a New Language and New Paradigms. En M. Rahnema \& V. Bawtree (Eds.), The PostDevelopment Reader. London: Zed Books.

Rawls, J. (1996). Teoría de la justicia. Mexico: FCE.

Rawls, J. (2004). El liberalismo político. Barcelona: Editorial Crítica.

Restrepo, E. (2002). Políticas de la alteridad: etnización de 'comunidad negra' en el Pacífico sur colombiano. Fournal of Latin American Anthropology, 7(2), 34-58.

Restrepo, E. (2005). Políticas de la teoría y dilemas en los estudios de las Colombias negras. Popayán: Editorial Universidad del Cauca.

Restrepo, E. (2009). Raza/ etnicidad. En M. Szurmuk \& R. Mckee (Eds.), Diccionario de estudios culturales. Mexico: Siglo XXI.

Restrepo, E. (2010). Genealogía e impactos (no intencionados) de las intervenciones de desarrollo en el Chocó: el Proyecto de Desarrollo Integral Agrícola Rural (DIAR). En P. Vries \& E. Valencia, El DIAR ${ }_{i}$ Un fracaso o promesa no cumplida? (pp. 9-141). Quibdó: Universidad Tecnológica del Chocó .

Restrepo, E., \& Rojas, A. A. (2008).Afrodescendientes en Colombia: compilación bibliográfica. Popayán: Universidad del Cauca.

Rúa, C. (2004). La situación territorial de los afrocolombianos: problemas y conflictos. En M. Pardo, C. Mosquera \& M. Ramírez, Panorámica afrocolombiana. Estudios sociales en el Pacífico. Bogotá:[ICANH]; Universidad Nacional de Colombia.

Rubio, J. (2007). Teoría crítica de la ciudadanía democrática. Madrid: Trota.

Ruiz, D. (2006). Nuevas formas de ser negro. Consideraciones sobre las identidades entre la gente chilapa y negra del Bajo Atrato, en Colección Monografias No. 37. Caracas: Universidad Central de Venezuela.

Sachs, W. (Ed.). (1992). Introduction. En The Development dictionary: a guide to knowledge as power (pp. 1-5). New York: Zed Books.

Schmitter, P. (2005). Un posible esbozo de una democracia «post-liberal». En B. Arditi (Ed.), ¿Democracia post-liberal? El espacio político de las asociaciones. México D.F.: Anthropos.

Sen, A. (2009). La idea de la justicia. Bogotá D.C.: Taurus.

Torre de la, G. (30 de julio de 2010). Entrevista Misionero de la Diócesis de Quibdó y precursor de las organizaciones comunitarias en los años 80. Quibdó. 
Tugendhat, E. (1998). Ser-Verdad-Acción: Ensayos Fillosóficos. Barcelona: Gedisa.

Villa, W. (2004). El territorio de comunidades negras, la guerra en el Pacífico y los problemas del desarrollo. En M. Pardo, C. Mosquera \& M, Ramírez, Panorámica afrocolombiana. Estudios sociales en el Pacifico. Bogotá: Universidad Nacional de Colombia; INGANH.

Wade, P. (2000). Raza y etnicidad en Latinoamérica. Quito: Editorial Abya Yala. 


\section{Serie Investigación}

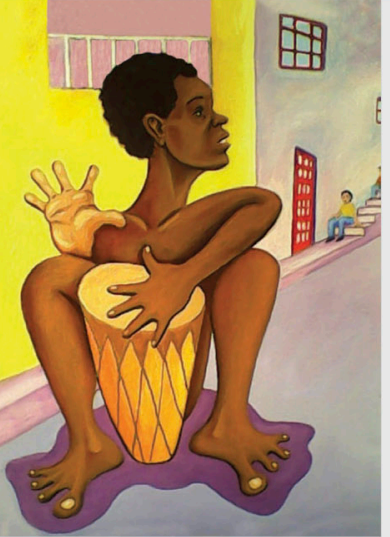

LOS CONSEJOS COMUNITARIOS DEL MEDIO

ATRATO EN LA VÍA DEL POSDESARROLLO

HACIA UN MODELO DELIBERATIVO DE ORGANIZACIÓN DE LAS COMUNIDADES NEGRAS

El libro que se entrega al lector tiene como propósito construir un puente de comunicación entre la democracia deliberativa y el posdesarrollo, buscando con ello establecer una lectura, no occidental, sobre los consejos comunitarios del Medio Atrato. Metodológicamente se fundamenta en un trabajo de campo elaborado en el Municipio de Quibdó en donde a través de entrevistas semiestructuradas en profundidad se indagó con diferentes actores sociales -Campesinos, lideres, misioneros, Consultivas, profesionales- sobre el fenómeno organizativo posterior a la Ley 70 de 1993. En este sentido, la indagación llevo a demostrar que los Consejos desde una concepción liberal de democracia, movilizan lógicas de burocratización, representación y corrupción que pervierten un modelo plausible de organización en defensa del territorio y los derechos étnicos. En consecuencia, sobre la base de visiones diferenciales sobre "la vida buena" se plantearán lineamientos generales que sirvan de insumo para la formulación de un modelo deliberativo de organización en el que las comunidades se sientan más a gusto con su propia identidad y en el que sea posible incluir racionalmente y razonablemente a todos los individuos.

\section{UNIVERSIDAD SERGIO ARBOLEDA}

Carrera 15 No. 74-40. Tels: (571) 3257500 ext. 2131 - 322 0538. Bogotá, D.C.

Calle 18 No. 14A-18. Tels: (575) 4203838 - 420 2651. Santa Marta

www.usergioarboleda.edu.co 